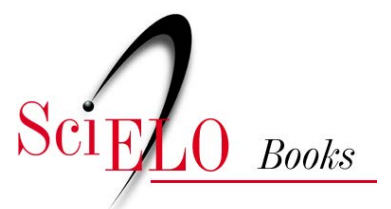

\title{
Arquivos da loucura: Juliano Moreira e a descontinuidade histórica da psiquiatria
}

\author{
Vera Portocarrero
}

PORTOCARRERO., V. Arquivos da loucura: Juliano Moreira e a descontinuidade histórica da psiquiatria [online]. Rio de Janeiro: Editora FIOCRUZ, 2002. 152 p. Loucura \& Civilização collection, v.4. ISBN 85-7541-019-9. Available from SciELO Books 〈http://books.scielo.org〉.

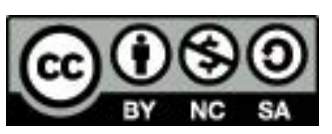

All the contents of this chapter, except where otherwise noted, is licensed under a Creative Commons Attribution-Non Commercial-ShareAlike 3.0 Unported.

Todo o conteúdo deste capítulo, exceto quando houver ressalva, é publicado sob a licença Creative Commons Atribuição Uso Não Comercial - Partilha nos Mesmos Termos 3.0 Não adaptada.

Todo el contenido de este capítulo, excepto donde se indique lo contrario, está bajo licencia de la licencia Creative Commons Reconocimento-NoComercial-CompartirIgual 3.0 Unported. 


\section{ARquivas DA LQUEURA}

JULIANם MOREIRA E A DESCONTINUIDADE HISTÓRICA DA PSIQUIATRIA 


\section{FUNDAÇÃO OSWALDO CRUZ}

Presidente

Paulo Marchiori Buss

Vice-Presidente de Desenvolvimento Institucional, Informação e Comunicação

Paulo Gadelha

\section{EDITORA FIOCRUZ}

Coordenador

Paulo Gadelha

Conselho Editorial

Carlos E. A. Coimbra Jr.

Carolina M. Bori

Charles Pessanha

Jaime L. Benchimol

José da Rocha Carvalheiro

José Rodrigues Coura

Luis David Castiel

Luiz Fernando Ferreira

Maria Cecilia de Souza Minayo

Miriam Struchiner

Paulo Amarante

Vanize Macêdo

Coordenador Executivo

João Carlos Canossa P. Mendes

Coleção loucura \& Civilização

Editor Responsável: Paulo Amarante 


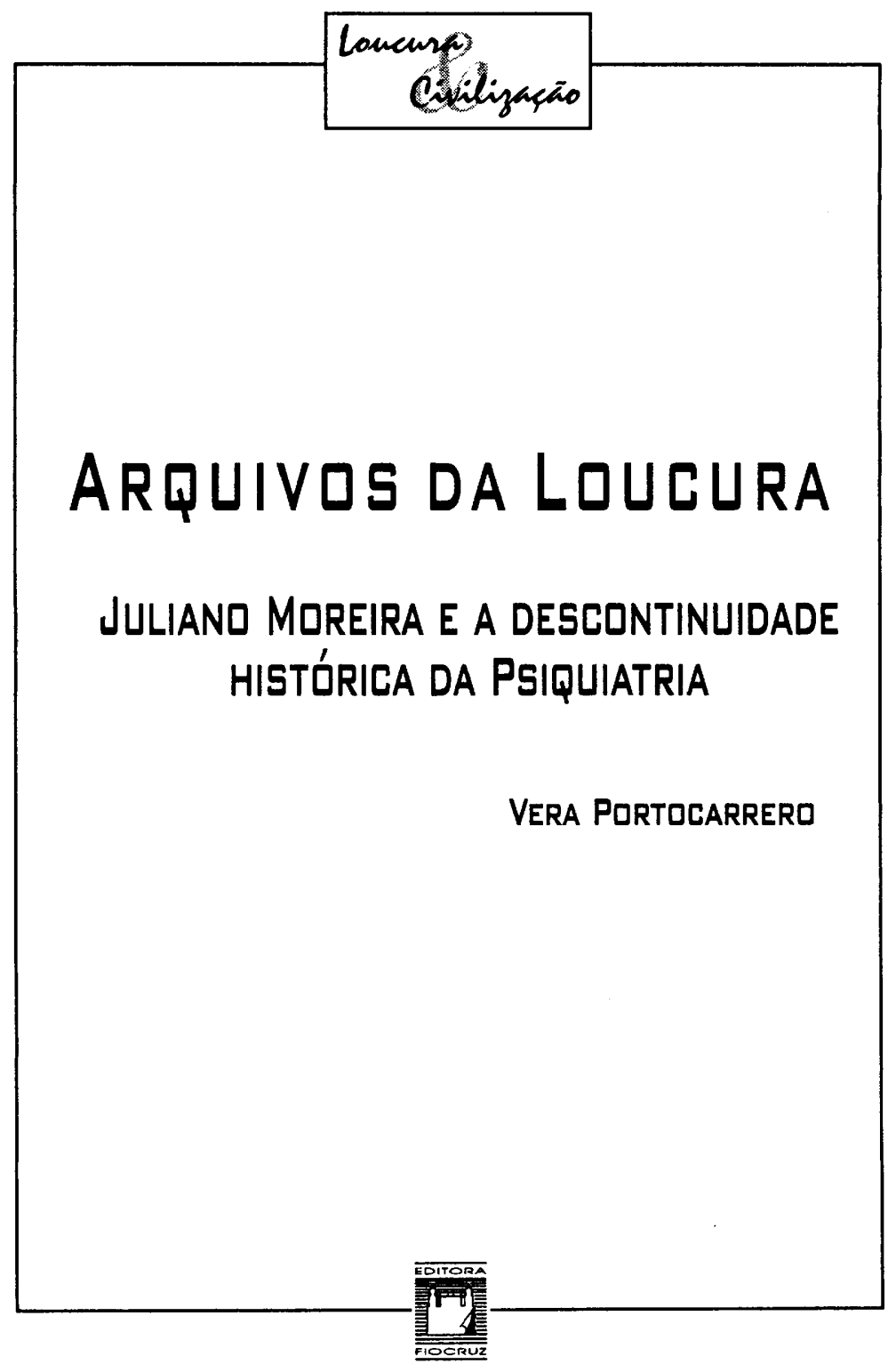


Copyright () 2002 by Vera Portocarrero

Todos os direitos desta edição reservados à

Fundaçāo OsWaLdo CRUZ / Editora

ISBN: 85-7541-019-9

Capa, projeto gráfico e editoraçáo eletrônica: Guilherme Ashton

Revisão: Irene Ernest Dias

Padronização e preparação de originais: Fernanda Veneu

Catalogação-na-fonte

Centro de Informação Cientifica e Tecnológica

Biblioteca Lincoln de Freitas Filho

P853a Portocarrero, Vera

Arquivos da loucura: Juliano Moreira e a descontinuidade histórica da psiquiatria. / Vera Portocarrero. Rio de Janeiro:

Editora FIOCRUZ, 2002.

152p. (Coleção Loucura \& Civilização, v. 4)

Bibliografia

1. Psiquiatria - história - Brasil. 2. Transtornos Mentais.

3. Prática Profissional.

CDD - 20.ed. - 362.2

2002

EDITORA FIOCRUZ

Av. Brasil, 4036 - $1^{2}$ andar - sala 112 - Manguinhos

21040-361 - Rio de Janeiro - RJ

Tels: (21) 3882-9039 e 3882-9041

Telefax: (21) 3882-9006

http://www.fiocruz.br

e-mail: editora@fiocruz.br

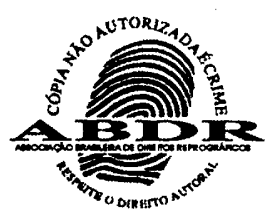




\section{SUMÁRIO}

Prefácio

Introdução

Parte I - A Teoria Psiquiátrica no Brasil: Nova Configuração NAS PRIMEIRAS DÉCADAS DO SÉCULO XX

1. Da Doença Mental à Anormalidade ........................................ 41

2. Um Novo Modelo Teórico .......................................................... 65

Parte II - O Século XX e a Nova Configuração da Pratica PSiquitatrica No Brasil ........................................................... 93

3. A Prática Psiquiátrica como Cura da Anormalidade ................. 107

4. Um Sistema Completo de Assistência aos Insanos ..................... 117

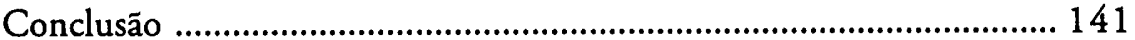

Referências Bibliográficas e Fontes ...................................................... 145 


\section{PREFÁCIO}

Esse escrito de Vera Portocarrero é um dos muitos frutos da história filosófica de Michel Foucault. Ao articular a arqueologia dos saberes à então recente genealogia dos poderes para falar em seu próprio nome, a atual professora da Universidade Estadual do Rio de Janeiro espelha o modo muito particular como se leu a obra do filósofo francês nos anos 70 .

Quando se considera o que hoje é escrito por quem foi de algum modo tocado pelas idéias de Foucault, nota-se facilmente que essa literatura filosófica está marcada pelo comentário, pela interpretação, pela análise interna de sua obra. Nessa perspectiva, Foucault vira um personagem da história da filosofia, tendo o seu pensamento dissecado pelo especialista de um período, de uma corrente filosófica, de um autor ou até mesmo de um livro. Justamente o que ele detestava. Não foi isso, por exemplo, que o levou a criticar, ainda na década de 70, a leitura que Derrida fez de sua Historia da Loucura, com um método que, segundo ele, reduzia as práticas discursivas aos traços textuais, em vez de situá-las no campo das transformações em que elas se efetuam? Não foi também isso que o fez lamentar, no início dos anos 80 , ter sido tratado por Habermas como autor de uma obra em que passado e presente estariam necessariamente em continuidade, como se sua filosofia formasse um sistema fechado, uma filosofia da identidade?

Marcado pela provisoriedade de um pensamento e de uma escrita que jamais desejou que continuassem os mesmos, mas se lançassem na direção do outro, do diferente, sempre em busca do novo, Foucault estava muito menos interessado na continuada busca de fundamentação de suas idéias do que no fato de que elas funcionassem com um instrumento provisório e parcial capaz de servir para que outros, que a ele recorriam, expusessem suas próprias idéias.

O que expressa um estudo como este de Vera Portocarrero é o desejo de um filósofo - categoria na qual eu me incluo ao escrever, com mais três amigos, a Danação da Norma - de utilizar livremente o pensamento de um 
grande filósofo como Foucault, que possuía a qualidade de não querer ser mestre de ninguém, para dar conta da exterioridade da filosofia e se articular à realidade política de seu país.

Por um lado, o descontentamento com a redução da atividade filosófica à mera repetição dos filósofos, como se o gosto da filosofia estivesse propriamente ou principalmente em passar a vida polindo seu instrumento, e não em utilizá-lo para produzir o novo, realizar suas próprias investigações, levando em consideração a conjuntura política e teórica em que se vive.

Por outro lado, a vontade de contribuir, teórica e politicamente, com os meios específicos de uma história filosófica das ciências ou dos saberes, para abalar as certezas de uma ciência do homem como a psiquiatria - mas o mesmo foi feito por outros pensadores em relação a outros domínios -, analisando suas origens e os momentos principais de suas transformações. Podia, assim, o filósofo participar, com uma contribuição própria, das lutas existentes no campo da saúde contra os efeitos de poder gerados por um tipo de saber que já estava sob suspeita de uma parcela relevante dos próprios técnicos encarregados de produzi-lo e exercê-lo.

Aprendemos com Michel Foucault que a psiquiatria é um saber situado historicamente. Isto é, um discurso de tipo médico sobre a loucura, que a considera doença mental, e uma prática que tem a finalidade de curá-la, por um tratamento físico-moral, só se constituem em determinado momento da história. Momento em que a loucura torna-se doença, fenômeno patológico, mas doença diferente, exigindo, por conseguinte, um tipo específico de medicina para tratá-la, justamente a psiquiatria.

Danação da Norma, querendo entender o que aconteceu historicamente no campo da saúde, no Brasil, relaciona a psiquiatria com a medicina social, partindo da idéia de que é no seio da medicina social que se constitui a psiquiatria brasileira; que é do processo de medicalização da sociedade que surge o projeto de patologizar o comportamento do louco, só a partir de então considerado efetivamente curável.

Ao escrever esse livro, observamos, a esse respeito, duas coisas. A primeira é que, no momento em que a medicina se dá como um de seus objetivos combater a desordem social decorrente da não-planificação da cidade, na primeira parte do século XIX, o hospital é percebido como causa de doença e até mesmo de morte, sendo para isso necessário transformar o seu espaço e funcionamento, para capacitá-lo a realizar a cura. A segunda é que, 
no momento em que o hospital se torna uma peça-chave da medicina, nasce, em 1852, o primeiro hospital psiquiátrico brasileiro, com o objetivo de inserir, como doente mental, uma população que começa a aparecer como desviante aos olhos da medicina social nascente.

Como isso se dá? Realizando os seguintes objetivos: isolar o louco da sociedade; organizar o espaço interno da instituição, possibilitando uma distribuição regular e ordenada dos doentes; vigiá-los em todos os momentos e em todos os lugares, através de uma 'pirâmide de olhares' composta por médicos, enfermeiros, serventes...; distribuir seu tempo, submetendoos à realidade do trabalho como principal norma terapêutica. Terrível máquina de curar, que levou o psiquiatra francês Esquirol a afirmar que, no hospício, o que cura é o próprio hospício. Por sua estrutura e funcionamento, ele deve ser um operador de transformação dos indivíduos: deve agir sobre os que abriga, atingir seu corpo, modificar seu comportamento.

Também data desse momento a formulação, no Brasil, da primeira teoria psiquiátrica da loucura, profundamente influenciada pelos franceses, principalmente Esquirol, o grande marco do nascimento da psiquiatria, que formula o conceito de uma doença mental - a monomania -, em que as idéias e os discursos dos alienados podem até mesmo ser considerados normais, visto que sua desordem se situa fundamentalmente no âmbito do comportamento, diz respeito aos hábitos, ao caráter, às açōes, às paixões do alienado. Os primeiros textos psiquiátricos escritos no Brasil, a partir de 1837 , confirmam esse desprestígio das faculdades intelectuais para caracterizar a loucura, que concerne agora fundamentalmente à conduta.

Mas, nessa época, o mais importante na produção brasileira sobre a alienação mental é, antes de tudo, seu papel de instrumento auxiliar de validação da medicina social, que, ao intervir na sociedade, percebe no louco um elemento de desordem urbana e prevê um lugar institucional para sua correção. Ao reivindicar ou louvar, em suas teorias, o isolamento do doente mental no asilo, seguindo o exemplo de Pinel e Esquirol, os médicos brasileiros formulam coerentemente o fundamental de seu saber e de suas pretensōes.

Assim, desde a criação do hospício, os psiquiatras brasileiros não se cansam de louvar o seu principal operador de cura: a cientificidade de sua organização espacial e funcional; a dedicação e competência de seu pessoal dirigente; a aplicação do tratamento moral. 
Mas o hospital psiquiátrico também sofre, desde a sua origem, severas críticas. E não só críticas externas. Principalmente críticas internas: de seus médicos ou seus diretores, que atacam sua organização arquitetônica, a subordinação do médico ao pessoal religioso, a ignorância ou maldade dos enfermeiros, o processo não-médico de internação, a falta de uma lei nacional de alienados e de um serviço de assistência organizado pelo Estado.

Essas críticas parecem explicitar, por um lado, a exigência de realmente medicar esse espaço de reclusão, evidenciando a dificuldade que a psiquiatria encontrou em sua luta para ordenar esse mundo da loucura com base nos critérios de cientificidade que ela reivindicava. Mas, por outro lado, e talvez mais fundamentalmente, essas críticas parecem patentear o fracasso da psiquiatria como uma instância terapêutica. Como se, ao mesmo tempo que oferece a cura como sua aquisição científica fundamental e produção específica do internamento asilar, a medicina mental não pudesse deixar de reconhecer que só se entra no hospício para não mais sair, ou, na melhor das hipóteses, para logo depois voltar.

Atenta, a partir de Foucault, às descontinuidades históricas, tanto no âmbito dos conceitos quanto no das práticas sociais, Vera Portocarrero analisa o que se tornou a psiquiatria brasileira a partir dessas críticas, na passagem do século XIX para o século XX, evidenciando em que consistiu esse novo capítulo de sua história. Tomando como marco a metamorfose produzida por Juliano Moreira e seus companheiros e discípulos, a atual professora de epistemologia e história dos saberes investiga esse novo momento da história da psiquiatria brasileira, privilegiando tanto seu novo modelo teórico quanto suas novas formas de assistência ou, de modo talvez mais preciso, seu discurso teórico e seu discurso social.

Por um lado, o surgimento de uma nova nosografia, não mais inspirada em Pinel, Esquirol e seus continuadores, com os conceitos de mania, monomania etc., e sim em Kraepelin, quando Juliano Moreira e os que, com ele, iniciam essa nova etapa da psiquiatria brasileira privilegiam o conceito de anormalidade, que agrupará, além dos doentes mentais, degenerados, epiléticos, criminosos, sifilíticos, alcoólatras. Mudança no âmbito saber, que, respondendo às exigências de se ajustar aos novos padrōes científicos surgidos na Europa, com a valorização da etiologia específica das doenças, busca fundar as teorias da psiquiatria em considerações menos morais do que fisiológicas, ou melhor, psicofisiológicas. 
Por outro lado, o surgimento de um sistema de assistência abrangente, que, a partir das novas concepçōes psiquiátricas, não se restringe mais ao doente mental, nem ao asilo fechado, pois, além da reforma do já velho hospício, propõe a institucionalização de novos espaços terapêuticos, como colônias agrícolas, reformatórios, manicômios judiciários, ambulatórios. Novas formas de institucionalização da psiquiatria que evidenciam como a nova categoria dos anormais, que funda um saber psiquiátrico considerado mais científico, torna possível dar conta de maneira mais fina de indivíduos considerados perigosos ou nocivos à sociedade.

Eis a questão ainda atual levantada por este estudo de história dos saberes, no momento em que os espaços de reclusão da loucura, em crise ainda mais profunda, parecem radicalmente criticados: que intensificaçáo dos efeitos de poder a expansão do modelo psiquiátrico concebido como uma radicalização de um processo de medicalização da sociedade pode produzir quando sāo refinados os critérios de cientificidade de seu saber?

Roberto Machado

Filósofo, doutor em filosofia, professor titular do Instituto de Filosofia e Ciências Sociais da Universidade Federal do Rio de Janeiro (IFCS/UFRJ) 


\section{INTRODUÇÃO}

Enunciemo-la, esta nova exigência: necessitamos de uma critica dos valores morais, o próprio valor desses valores deverá ser colocado em questäo - para isto é necessário um conhecimento das condiçōes e circunstâncias na quais nasceram, sob as quais se desenvolveram e se modificaram... Desde que para mim se abriu essa perspectiva, tive razöes para olhar em torno, em busca de camaradas doutos, ousados e trabalhadores (e ainda olho). Oobjetivo é percorrer a imensa, longinqua e recôndita regiäo da moral - da moral que realmente houve, que realmente se viveu - com novas perguntas, com novos olhos...

Nietzsche, Genealogia da Moral

Este livro dirige-se ao domínio do arquivo, das coisas efetivamente ditas, para mostrar uma descontinuidade entre a psiquiatria brasileira do século XIX e a psiquiatria introduzida no Brasil por Juliano Moreira no início do século XX. É um livro de história dos saberes.

Tal descontinuidade ${ }^{1}$ se estabelece no âmbito tanto do saber como da prática, sobretudo a partir do surgimento do conceito de anormal como uma forma de psicopatologia, no final do século XIX, que fará a psiquiatria abranger não somente a doença mental propriamente dita, como ocorreu até Juliano Moreira, mas todo e qualquer desvio do comportamento normal, como o dos degenerados, epiléticos, criminosos, sifilíticos e alcoólatras. ${ }^{2}$

\footnotetext{
${ }^{1}$ A noção de descontinuidade histórica permite traçar mudanças e transformaçōes dos discursos, cujos desdobramentos históricos nāo seguem os esquemas de evolução, não obedecem ao ritmo lento e progressivo da história, nem aos fenômenos de sucessão e de encadeamentos temporais lineares da história tradicional das idéias. Ela permite traçar o momento do surgimento e do desaparecimento de uma determinada forma do saber e das práticas a ele articuladas.

${ }^{2}$ Juliano Moreira representa o primeiro esforço de elaboração de um corpo teórico científico no Brasil, ao rejeitar a simples compilação das teorias psiquiátricas francesas. Ele introduziu, no início do século XIX, o modelo teórico e assistencial baseado na psiquiatria alemã, representado pelo eminente psiquiatra Emil Kraepelin. Juliano Moreira ocupou, de 1903 a 1930, o cargo de diretor geral da Assistência a Psicopatas do Distrito Federal. Conseguiu a promulgação de
} 
No concernente à teoria, essa ruptura se caracteriza pela possibilidade e pelo estabelecimento de uma nova nosografia, como a de Kraepelin, que em seu Tratado de Psiquiatria, de 1926, classifica, 'cientificamente', todos os casos de anormalidade, e de um modo geral, de um corpo conceitual que justifica, com base na medicina 'científica', o seqüestro do louco e a intervenção psiquiátrica sobre os indivíduos anormais. No concernente à prática, a ruptura se manifesta na criação de um sistema de assistência abrangente, que não se restringe mais ao doente mental, nem se limita ao espaço do asilo fechado, como no século XIX. No século XX, a prática psiquiátrica incidirá sobre aqueles que apresentam desvios mentais, atuais ou potenciais, loucos ou virtualmente loucos, e penetrará em instituições, como a família, a escola, as Forças Armadas, com o objetivo terapêutico e preventivo de lutar contra a criminalidade e a baixa produtividade, combatendo a doença mental propriamente dita e a anormalidade.

Admitindo a psiquiatria como tendo, no Brasil, sua constituição diretamente ligada ao projeto da medicina social, que surge como saber e como prática social no século XIX, ao incorporar a sociedade como objeto e impor-se como instância de controle social dos indivíduos e das populações; ${ }^{3}$ admitindo, ainda, que no decorrer de todo esse século a psiquiatria lutou para se impor como ciência médica e como saber necessário à sociedade, descrevo seu discurso, ${ }^{4}$ assinalo suas rupturas, a fim de compreender sua nova configuração no início do século $\mathrm{XX} .^{5}$

uma lei de reforma da assistência a alienados. Remodelou o antigo Hospício de Pedro II (retirada das grades, aboliçáo dos coletes e das camisas de força), onde instalou um laboratório. Criou, em 1911, a Colônia de Engenho de Dentro. Instaurou a admissão voluntária de insanos e assistência heterofamiliar. Em 1919, inaugurou o primeiro Manicômio Judiciário do Brasil.

${ }^{3}$ Em Danação da Norma, fica claro que a "medicina social não é uma exigência médica nascida na atualidade, fruto de uma posiçáo de luta contra a situaçáo da medicina capitalista em um país capitalista; como também não é uma característica fundamental da teoria e da prática médicas de todas as épocas. Foi em determinado momento de nossa história que nasceu um tipo específico de medicina que pode ser chamada de medicina social pela maneira pela qual problematizou a questão da saúde da população e procurou intervir na sociedade de maneira global" (MACHADO, 1978:54).

${ }^{4}$ Cumpre esclarecer que discurso, aqui, tem o sentido foucaultiano não de teorias ou abstraçôes, mas de práticas que apresentam uma materialidade e cuja formação se relaciona necessariamente com a formaçóes ao nível não discursivo. (Cf. FouCAult, 1969).

${ }^{5}$ Esta pesquisa, de inspiração foucaultiana, tem como ponto de partida Daną̧ão da Norma (1978), no qual a constituição da psiquiatria no século XIX é analisada como prática social, compreendida no contexto - mais amplo - do projeto da medicina social: "Só é possível portanto compreender o nascimento da psiquiatria brasileira a partir da medicina que incorpora 
O novo modelo psiquiátrico introduzido no Brasil por Juliano Moreira e seus contemporâneos é, aqui, considerado como um discurso que, mesmo quando não legitimado pela cientificidade, possui uma positividade - a positividade do reconhecimento do saber como efetivo, e que só pode ser submetido ao critério da história e não ao da racionalidade, da verdade ou do erro, específico das histórias das ciências. ${ }^{6}$ Não vou, portanto, deter-me exclusivamente nos limites da ciência, do discurso reconhecido como conhecimento 'verdadeiro'. O saber ${ }^{7}$ é que será analisado - o discurso em seu valor estratégico -, para apontar uma articulação da psiquiatria com a gestão política do espaço social. Neste nível, o saber não está investido apenas nas demonstraçôes lógicas e teóricas; ele pode estar investido também nas ficçōes, nas reflexões, nas narrativas, nos regulamentos institucionais e nas decisōes políticas.

Nessa perspectiva é que se coloca a questão que guia a análise: até que ponto o novo modelo psiquiátrico, desenvolvido no Brasil por Juliano Moreira, com suas novas formulaçōes no campo científico e suas novas formas de assistência, significa uma ruptura no âmbito do saber e da prática

a sociedade como novo objeto e se impõe como instância de controle social dos indivíduos e das populaçōes. É no seio da medicina social que se constitui a psiquiatria. Do processo de medicalização da sociedade, elaborado e desenvolvido pela medicina que explicitamente se denominou política, surge o comportamento do louco, só a partir de entāo considerado anormal e, portanto, medicalizável" (MaCHaDo, 1978: 376).

- Ao contrário da noção de positividade, a noção de cientificidade designa o progresso da verdade e sua história, processo contínuo, para os positivistas, ou descontínuo, para os epistemólogos que apontam rupturas entre o erro e a ciência, ou entre a pré-ciência e a ciência finalmente verdadeira. Como afirma Foucault, ao demarcar a diferença de suas pesquisas com relação à epistemologia, às histórias das idéias, das mentalidades, e das opiniōes: "Mas, do ponto de vista da racionalidade dos conhecimentos, podemos falar de pré-história, no caso das positividades, só podemos falar de história tout court" (Foucault, 1966:232).

${ }^{7}$ Saber aqui tem o sentido, que lhe é conferido por Foucault, de categoria metodológica, significando o nível dos discursos considerados como práticas que obedecem a regras de formação e transformação, e que podem ser analisados não como signos de um 'outro discurso' mais escondido, mas como tendo um volume próprio; não como documento, mas como monumento. (FouCAULT, 1969:184). O saber pode ser considerado um conjunto de elementos estratégicos utilizados contra os efeitos de poder centralizador. Pode-se agrupar numa mesma categoria discursos aparentemente diversos: "Poder-se-ia dizer que existe um estranho paradoxo em querer agrupar em uma mesma categoria de saber dominado os conteúdos do conhecimento histórico, meticuloso, erudito, exato e estes saberes locais, singulares, estes saberes das pessoas que são saberes sem senso comum e foram deixados de lado, quando não foram efetivamente subordinados. Parece-me que, de fato, foi este acompanhamento entre saber sem vida da erudição e o saber desqualificado pela hierarquia dos conhecimentos e das ciências que deu lugar à crítica destes últimos anos sua força essencial (FouCAULT, 1982:170). 
psiquiátricos, e quais as condiçōes de possibilidade dessa mudança. Gostaria de esclarecer, desde logo, que essa questão não será tratada de acordo com uma visão internalista de história da ciência, ou seja, voltada para a análise do desenvolvimento teórico da ciência sobre alienação mental, com o objetivo de detectar uma passagem para um conhecimento cada vez mais científico. Não se trata de uma epistemologia para a qual o progresso da ciência é uma característica essencial, para a qual a história, a dos conceitos operatórios, é um processo em direçáo à verdade cada vez mais depurada dos erros iniciais. E tampouco orientada por uma visão externalista, que subordinaria o novo modelo da psiquiatria às condiçóes econômicas e políticas externas à ciência.

Essa distinção de duas modalidades de história, a internalista ou a externalista, tem como base uma hipótese foucaultiana, a de que há duas histórias da verdade: por um lado, uma espécie de história interna de uma verdade que se corrige a partir de seus próprios princípios de regulaçāo, tal como se faz na ou a partir da história das ciências.

Por outro lado, parece-me que existem, na sociedade, ou pelo menos em nossas sociedades, vários outros lugares onde a verdade se forma, onde um certo número de regras de jogo são definidas - regras de jogo a partir das quais vemos nascer certas formas de subjetividade, certos dominios de objeto, certos tipos de saber - e por conseguinte podemos, a partir dat,

fazer uma bistória externa, exterior, da verdade. (Foucault, 1999:11)

Pretende-se, aqui, levar em consideração a articulação ${ }^{8}$ dos discursos com as práticas não discursivas - sociais e políticas - enquanto desempenham um papel intrínseco na constituição de um novo corpo teórico e de novas práticas de assistência, tal como se apresentam, por meio da pesquisa das fontes documentais - teses, artigos publicados em revistas médicas e psiquiátricas, atas de reuniōes das sociedades psiquiátricas, regulamentos dos asilos psiquiátricos -, comparando-os com as formas históricas que o precedem, para apontar um momento inovador do saber e da prática psiquiátricos brasileiros. ${ }^{9}$

\footnotetext{
${ }^{8}$ Tal articulação não se dá numa linha de causalidade, ou seja, não tenta compreender de que maneira as práticas políticas e econômicas determinam a consciência dos homens e vêm assim influenciar seus discursos. Essa articulação é possível devido ao pressuposto foucaultiano da relação de imanência entre os discursos e certos princípios de organização dos saberes que podem ser situados como elementos de um dispositivo essencialmente político; basta que haja uma prática discursiva para haver saber.

${ }^{9}$ É interessante notar a relação entre a medicina e a loucura na história traçada por Foucault. Como é ressaltado em Foucault, a Filosofia e a Literatura, "Fazendo, mais ou menos no estilo do epistemólogos, uma história que recua no tempo e procura compatibilidades e incompatibilidades entre saberes do presente - no caso, a modernidade - e saberes do passado - o classicismo -, Foucault descobriu algo muito original e importante: primeiro, que em um
} 
O plano desta pesquisa se estabelece seguindo a própria temática psiquiátrica, a partir da forma como aparece nos documentos da época. A análise foi dividida em duas partes: a teoria psiquiátrica e a assistência ao doente mental, dois aspectos diferentes de um mesmo saber, que assim podemos considerar, na medida em que constituem dois tipos de discurso com características próprias, às vezes até contraditórias entre si: o discurso teórico de um lado, e o discurso social da psiquiatria do outro; ora a doença mental aparecendo caracterizada como um problema psicossomático, individual, ora a doença mental relativa a um mal social, resultante de desvios como alcoolismo e outros então considerados causa de decadência da humanidade.

Mas as contradiçóes, às vezes encontradas, não são analisadas em função de uma possível restituição histórica de uma coerência lógica oculta. Elas são descritas com o objetivo de delimitar a possibilidade de se articular o saber com o campo da instituição e das técnicas de assistência. ${ }^{10}$

período recente da história ocidental, que se estende até a Revolução Francesa, ainda não existia a categoria psiquiátrica de doença mental; segundo, que antes de se tornar doença mental - com Pinel, Esquirol e os psiquiatras do final do século XVIII e início do XIX -, a loucura era simplesmente doença, e como doença estava integrada, como as outras doenças, no tipo específico de racionalidade médica próprio da época clássica. Foucault aprofundará esse aspecto da História da Loucura em seu livro seguinte, $O$ Nascimento da Clínica, quando mostrará que a medicina clássica é uma medicina classificatória, uma medicina das espécies patológicas, que, seguindo o modelo da história natural, em relaçáo às plantas e aos animais, estabelece identidades e diferenças entre as doenças, organizando um quadro em termos de classes, ordens, espécies. Para a racionalidade médica do século XVIII, a loucura é uma doença situada no jardim das espécies patológicas. (...) Não há, portanto, na época clássica, (...), uma medicina especial, como a psiquiatria, fundada na distinção entre o físico e o mental. Foucault salienta as dificuldades, resistências ou obstáculos que o conhecimento da loucura encontra para se integrar na racionalidade médica clássica. É que, desrespeitando seus princípios, ao fazer denúncias morais e estabelecer causalidades físicas, ou manter inalteradas algumas noções imaginárias mais essenciais do que seus conceitos, ou ainda utilizar teorias como as dos vapores e das doenças dos nervos, ligadas à prática terapêutica, mas estranhas à medicina classificatória, o conhecimento da loucura não permite que ela entre completamente na ordem racional da espécies patológicas" (MaCHADO, 2000:15-16).

${ }^{10} \mathrm{~A}$ instituiçāo é considerada como um ponto de passagem e de produção de saber e de relaçōes de poder. Aliás, como afirma Foucault, os discursos são elementos de um dispositivo essencialmente político; considerados como uma série de segmentos descontínuos, cuja função tática não é uniforme nem estável, os discursos veiculam, produzem ou debilitam o poder. Nos discursos podemos analisar as correlaçóes de forças codificadas, pois constituem o ponto de interseção entre a teoria e a prática, entre o saber e o poder. Os discursos permitem, portanto, questionar, por um lado, sua produtividade tática, os efeitos recíprocos de poder e saber que proporcionam; por ouro lado, sua integraçáo estratégica, ou seja, a conjuntura e as correlaçōes de forças que tornam necessárias a sua utilização nos confrontos produzidos na vida concreta. 
No início do século XX, o discurso teórico remete-nos a uma nosografia, à composição do quadro de classificação dos tipos de doença mental, que constitui a racionalidade supostamente médica, à qual a elaboração teórica procura se integrar cada vez mais. Por outro lado, o discurso social da psiquiatria remete à prática, ou melhor, à questão da assistência que, através da legislação e de novas modalidades de assistência asilar ou não asilar, nos permite compreender as condiçōes de possibilidade de suas formaçóes discursivas.

Entre os dois, há uma nova forma de articulação que caracteriza a psiquiatria brasileira do início de nosso século. Essa forma de articulação se manifesta de modo bastante claro quando a psiquiatria se dirige ao problema da assistência ao alienado mental e assimila à nosografia o modelo de Kraepelin. Daí a divisão da pesquisa em duas partes principais: a primeira referente à teoria, baseada na análise de novo modelo teórico introduzido no Brasil por Juliano Moreira; e a segunda parte, em que trato da assistência psiquiátrica do início do século $\mathrm{XX}$, considerando a reforma do hospício, a criação de colônias agrícolas e a proposta de reformatórios, relacionando-as com o Programa de Higiene Mental.

Com Juliano Moreira, a questão da importância da açáo da psiquiatria em nossa sociedade se apresenta sobretudo nos termos daquilo que se realiza na Europa, naquele momento, a partir das novas concepções psiquiátricas que devem ser instituídas na prática asilar e nos serviços de assistência. A argumentação fundamental não é mais um trabalho de imposição da idéia de criação de um espaço especial, terapêutico, para o alienado, como aconteceu anteriormente, pois o louco já havia sido retirado, tanto quanto possível, das prisōes e das enfermarias das Santas Casas da Misericórdia, e não perambulava mais pela cidade desde o início do funcionamento do Hospício de Pedro II, em 1852. ${ }^{11}$ A prática asilar européia em relação à doença mental se encontrava difundida em nossa sociedade, se não na aplicação prática propriamente dita, pelo menos no que diz respeito a seus princípios; tratava-se, então, de aprofundar o debate sobre a teoria psiquiátrica e redefinir quais seriam os melhores meios de assistência e as medidas terapêuticas mais eficazes.

${ }^{11} \mathrm{O}$ aparecimento do louco no século XIX como perigoso em potencial e como atentado à moral pública, à caridade è segurança gerou crítica, por parte dos médicos, contra a situação do louco nas ruas e no hospital da Santa Casa da Misericórdia. A crítica do hospital é parte central da argumentação pela necessidade de um hospício. A idéia básica é que o Hospital da Misericórdia, onde se encontravam os loucos antes do funcionamento do hospício, oferecia condiçóes para abrigar medicamente e recuperar o louco. A assinatura, em 1841, do decreto para criação do Hospício de Pedro II é a primeira vitória desse posicionamento médico, que assinala, como marco institucional, o nascimento da psiquiatria. (Cf. MACHADO et al., 1978:375-378) 
No Brasil, a elaboração de um novo corpo teórico se impôs cada vez mais como necessária para conferir cientificidade à relação da psiquiatria com a prática da assistência. Foi de acordo com a nova concepçáo de alienação como anormalidade que se argumentou em favor de um projeto de criação de asilos com características arquiteturais especiais para tipos diferentes de alienados, mais do que de acordo com as condiçōes econômicas e sociais de viabilidade, visto que tentava-se sempre ser o mais fiel possível aos preceitos científicos da época e às propostas das novas modalidades de assistência. Embora pudessem, eventualmente, auxiliar nas dificuldades financeiras, nenhuma delas se apresentava como uma solução efetiva para o problema econômico da assistência aos chamados psicopatas.

Aparentemente, o discurso teórico e a prática psiquiátrica são independentes entre si. Entretanto, para podermos compreender de que modo se constitui a novidade da psiquiatria do início do século XX em relação ao modelo que o precede, será preciso não só explicitar o modo de ligação do discurso com a prática desse momento, mas diferenciá-lo do momento anterior, assinalando as continuidades e descontinuidades históricas aí encontradas.

Essa ligação explicita-se na articulação das práticas discursivas com um contexto mais amplo do que a própria medicina mental, que éo projeto de medicalizaçáo da sociedade, iniciado no Brasil no século XIX, ${ }^{12}$ acirrado no momento de implantação da República Velha pela medicina. Esta, ao investir sobre a cidade, ${ }^{13}$ disputa um lugar entre as instâncias de controle da vida social, sob alegação

12 "É no seio da medicina social que se constitui a psiquiatria. Do processo de medicalizaçāo da sociedade, elaborado e desenvolvido pela medicina que explicitamente se denominou política, surge o comportamento do louco, só a partir de então considerado anormal e, portanto, medicalizável" (MACHADO et al., 1978:376). "Antes do século XIX, afirma Machado, não se encontra, seja nas instituiçōes propriamente médicas, seja no aparelho de Estado, a relação explícita entre saúde e sociedade, que hoje chega a aparecer como óbvia e atemporal" (MACHADO et al., 1978:154).

${ }^{13}$ Em Danação da Norma, afirma-se que "quando se investiga a medicina do século passado [século XIX] - em seus textos teóricos, regulamentos e instituiçóes - se delineia, cada vez com mais clareza, um projeto de medicalização da sociedade. A medicina investe sobre a cidade, disputando um lugar entre as instâncias de controle da vida social. (...) O conhecimento de uma etiologia social da doença corresponde ao esquadrinhamento do espaço da sociedade com o objetivo de localizar e transformar objetos e elementos responsáveis pela deterioraçáo do estado de saúde das populaçōes. Projeto, portanto, de prevençāo, isto é, ação contra a doença antes mesmo que ela ecloda, visando a impedir o seu aparecimento. O que implica tanto na existência de um saber médico sobre a cidade e sua população, elaborado em instituiçōes - faculdades, sociedades de medicina, imprensa médica, etc. - quanto na presença do médico como uma autoridade que intervém na vida social, decidindo, planejando e executando medidas ao mesmo tempo médicas e políticas" (MACHADO, 1978:18). 
de que possui o saber sobre a doença e a saúde, a partir do qual se atribui o poder de planificar as medidas necessárias à manutenção da saúde entendida como catalisadora do equilíbrio da estrutura social instaurada; é a medicina mental que penetra nos vários setores do espaço social, através de seu corpo conceitual e de práticas assistenciais menos restritas ao internamento no hospício, procurando encontrar a alienação mental em todos os lugares, gestos, palavras e açóes. ${ }^{14}$

A primeira investida da psiquiatria nesse sentido voltou-se para a aquisição de poder político para uma ação profissional dentro e fora do hospício. Esse poder, através de muitas lutas, ${ }^{15}$ foi sendo incrementado, e desde o final do século XIX via-se cada vez mais reforçado, à proporção que se sustentava como saber científico, mostrando-se fundamentado na interação de seu discurso com a medicina. A relação da psiquiatria com a medicina permitiria garantir a função do psiquiatra de apoio cientifico indispensável ao exercício de poder do Estado. ${ }^{16} \mathrm{~A}$ medicina já havia penetrado na socie-

14 Joel Birman comenta a esse respeito: "A medicina mental através de sua trama conceitual, procurará encontrar a alienação mental em todos os lugares, gestos, palavras e açōes. Há uma evidente ofensiva da psiquiatria no sentido de fundamentar um conjunto de práticas sociais e morais, de invadir regiōes estabelecidas pela tradiçāo histórica. $O$ objetivo da psiquiatria será hipostasiado, expandindo-se para todos os setores da sociedade. Movimento de patologização do espaço social, que é apenas um aspecto de um movimento mais amplo que entáo se passava, de medicalizaçáo da sociedade. É neste contexto conflitivo que o Direito procura manter o seu campo de ação, opondo-se à penetração psiquiátrica na sua região de regulação entre os homens. A psiquiatria procura recortar no campo empírico do comportamento criminoso, alguns aspectos que seriam relevantes do ponto de vista médico-psicológico. Alguns criminoso não teriam livre arbítrio, seriam automaticamente impulsionados por seus instintos, frente aos quais não teria, possibilidade de se autocontrolarem. Nestas situaçōes, como julgar um criminoso e responsabilizá-lo perante a lei?" (BIRMAN, 1978:8).

${ }^{15}$ Lutas dos médicos impondo sua racionalidade por meio de "táticas variadas, como as de assessoria, de crítica e de penetraçáo civil", orientadas para a intervenção política, ou seja, atuando nas estruturas centrais de poder, oferecendo uma instrumentalização com saberes regionais, especializados, a fim de que o próprio exerćcio do poder político se torne viável (MACHADO et al., 1978:157-158).

16 "O século XIX, afirma-se em Danação da Norma, assinala para o Brasil o início de um processo de transformação política e econômica que atinge igualmente o âmbito da medicina, inaugurando duas de suas características, que nāo só têm vigorado até o presente, com têmse intensificado cada vez mais: a penetraçáo da medicina na sociedade que incorpora o meio urbano como alvo da reflexăo e da prática médicas, e a situação da medicina como apoio científico indispensável ao exercício do poder do Estado. (...) O médico torna-se cientista social, integrando à sua lógica a estatística, a geografia, a demografia, a topografia, a história; torna-se planejador urbano: as grandes transformaçōes da cidade estiveram a partir de então ligadas à questão da saúde; torna-se, enfim, analista de instituiçōes" (MACHADO, 1978: 155). 
dade como conhecimento científico, ao incorporar o meio urbano como alvo da reflexão e da prática médicas, por meio do deslocamento de seu objetivo da doença para a saúde. A partir do século XIX, a medicina é considerada uma prática política específica e com poder especializado para assumir o cuidado dos indivíduos e da população.

A ruptura com as práticas 'negativas' de isolamento ${ }^{17}$ e sobretudo com as teorias psiquiátricas próprias do século $\mathrm{XIX}^{18}$ permitiu a interação da psiquiatria com a medicina e, conseqüentemente, o reforço político procurado. Os textos do médico alienista Juliano Moreira são fundamentais para o estudo desse momento. Eles introduzem, no Brasil, novas práticas, por meio da adesão ao modelo alemão, abrindo a discurso da psiquiatria a uma atitude tida como científica para instituir novas formas de assistência aos alienados no Rio de Janeiro.

Ao contrário do que aconteceu no século XIX, o novo saber psiquiátrico no início do século XX não foi um processo apenas de transposição de modelos. Ele teve um desenvolvimento próprio, com pesquisas realizadas no campo da ciência pelos próprios psiquiatras brasileiros. Isso foi percebido pelos alienistas, que o caracterizavam como uma revolução, inclusive na maneira como se explicita a intenção de lutar para que os novos conhecimentos interfiram na prática asilar.

${ }^{17}$ Os loucos eram isolados no hospício, na prisão ou nas enfermarias da Santa Casa, onde não recebiam tratamento médico especializado. Como ressalta Paulo Amarante (1983), foi somente com a chegada da famflia real ao Brasil que se exigiu uma intervenção propriamente estatal com o objetivo de ordenar a sociedade, tornando a loucura objeto de intervenção específica por meio do Estado e da medicina: "Em 1830, uma comissão da Sociedade de Medicina do Rio de Janeiro realizou um diagnóstico da situação dos loucos. Só então é que estes passaram a ser considerados como doentes mentais, merecedores de um espaço social próprio para sua reclusão e tratamento. Antes, eram encontrados em todas as partes, menos nos hospitais: ora nas ruas, ora nas prisōes e casas de correção, oram em asilos de mendigos, ora nos porōes (nunca nas enfermarias da Santas Casas)" (Amarante, 1983:149).

${ }^{18}$ No século XIX, as teorias psiquiátricas mais conhecidas no Brasil eram a de Esquirol e as teorias organicistas de Magnan e Charcot. Como explica Robert Castel, no início do século XIX, ressalta-se o impasse gerado pela pesquisa nosográfica, do ponto de vista da exploração das lesōes do cérebro, bem como sua incompatibilidade com os princípios da medicina 'cientifica'. O isolamento era então considerado, juntamente com a pedagogia médica, um dos principais meios morais de cura, porque age diretamente sobre o delírio, quer dizer, sobre o sintoma. Mas, como mostra Castel, ao preço de uma inconseqüência surpreendente, porque sua superioridade deve-se ao fato de agir tambem diretamente sobre as 'causas' da loucura, sendo estas morais. Passa-se da sintomatologia à etiologia, à psicogênese. Com a teoria da degenerescência de Morel e seu discípulo Magnan, opera-se uma inversão completa com relação à concepção de alienação mental: abandono da teoria de Esquirol, busca de uma causalidade escondida, organicismo, ligação à medicina geral (CASTEL, 1976:114; 276-8). 
Afrânio Peixoto, em 1931, assim descreveu a situação do Rio na época em que surgiram as grandes transformaçōes do corpo teórico e das práticas asilares:

As boas irmäs de caridade tinham sido varridas pelo jacobinismo positivista, mas, em vez de casas-forte, contra demoníacos, havia colete de força, contra as agitaçōes. Havia o magister dixit. Havia uma classificaçāo: Magnan e Charcot imperavam. Era uma cidade fortificada, em que o prestígio do comando vinha de um estado-maior leigo, nas secretarias de Estado, Política e Psiquiatria. (Peixoto, 1931:47)

Afrânio Peixoto exaltava o espírito crítico que a psiquiatria brasileira começava a apresentar e ressaltava o caráter científico que se manifestava, em sua opinião, na prática psiquiátrica orientada por Juliano Moreira, visto que nenhuma obra de assistência psiquiátrica se realizava sem sua interferência, como aponta Cunha Lopes em Notícia Histórica da Assistência a Psicopatas no Distrito Federal (1939).

É o tempo da razão, inteligente, compreensiva, razão. Portanto, um psicólogo [Juliano Moreira], que bem conbece os homens, um alienista que bem os sabe tratar. Ese o coração inteligente faz isso, a razão nobre anda, aprova, concorda, doutrina suavemente, discorda concordando, e estudos, obras, colônias e leis são derivą̧ōes beneméritas dessa ciência benigna e benfazeja. (Moreira, 1931:47)

A psiquiatria é considerada então como um novo tipo de análise, mais próximo dos padrões científicos, com propostas médicas mais abrangentes, em contraposição ao discurso psiquiátrico do século XIX, que se pretendia científico mas via-se constantemente entranhado por princípios morais dificilmente conectáveis teórica e praticamente com o elemento fisiológico, único aceito para conferir cientificidade. Essa forma como a medicina via a si mesma acentuava cada vez mais a necessidade de medicalização do saber psiquiátrico, ${ }^{19}$ correspondente ao projeto de uma medicina social que se impunha desde o momento de sua constituição no Brasil, no século XIX.

Para melhor compreendermos a psiquiatria brasileira no século $\mathrm{XX}$, é necessário analisarmos essa ciência numa abordagem histórica, mostrando as diferentes modalidades com que foi-se apresentando ao longo do tempo e descrevendo o mencionado momento de ruptura, de constituiçáo de novos conceitos e de novas formas de institucionalização. É preciso investigar as mudanças do final do século XIX, a passagem de uma psiquiatria eminentemente moral, baseada na teoria de Esquirol (1838), para uma medicina mental, que pretende fundamentar cientificamente a prática psiquiátrica.

${ }^{19}$ Para Robert Castel (1976), o essencial na medicalização da loucura não é a relação médicodoente, mas a relação medicina-hospitalização, o desenvolvimento de uma tecnologia hospitalar, o desdobramento de um novo tipo de poder na instituiçăo e a aquisiçăo de um novo mandato social a partir de práticas centradas sobretudo nos asilos. 
No âmbito da prática, será necessário compreender uma mudança radical. Com Juliano Moreira e Franco da Rocha, implanta-se um sistema de assistência que ultrapassa os limites da psiquiatria do século XIX, que não se restringe mais a assistir ao louco, no espaço asilar determinado do hospício, mas, ao contrário, procura ser o mais abrangente possível, tentando criar novas modalidades de assistência para contemplar todos os indivíduos, loucos propriamente ditos, ou que podem se tornar loucos, ou simplesmente anormais.

Tal mudança evidencia uma descontinuidade na prática psiquiátrica, uma ruptura entre uma prática baseada no princípio do isolamento no hospício, até o final do século XIX, e um novo modelo, que comporta uma diversidade de formas, não mais necessariamente asilares, como as colônias agrícolas, o manicômio judiciário e a assistência familiar, além do próprio hospício. A nova concepção de hospício reflete o afastamento do princípio de isolamento e a rejeição de certas medidas de repressão física, como as grades e os coletes de força, utilizados anteriormente.

Trata-se, no novo modelo, de uma prática terapêutica e preventiva ampliada. A partir da última década do século XIX, a psiquiatria dirige-se ao indivíduo em todas as suas manifestaçóes psíquicas patológicas, por ela reconhecidas, procurando saná-las nas suas causas mais remotas. É estabelecido um princípio de causalidade, incluindo-se dentre as causas diversos estados mentais considerados sãos, mas patológicos em potencial, que passam a ser concebidos como anormalidades, no sentido que lhes é conferido pela chamada medicina científica.

A hipótese a ser estudada é a de que a concepção de anormalidade especificada nos vários tipos de comportamentos anti-sociais ou não disciplinados, juntamente com as disposiçōes fisiológicas, como intoxicações, degenerescências que lesionam o sistema nervoso ou alguma parte do cérebro - determina a delimitação das novas modalidades assistenciais, que compóem um sistema 'completo' de assistência ao alienado, característico da psiquiatria brasileira a partir de Juliano Moreira.

Essa hipótese tem o seguinte ponto de partida: a compreensão da loucura - das práticas e dos saberes por meio dos quais nossa sociedade lida com certas formas de comportamento consideradas desde Pinel como doenças mentais - remete, a partir do século XIX, à questão da anormalidade. Refiro-me à anormalidade como um objeto histórico, considerando-o um dispositivo a ser analisado na perspectiva foucaultiana. 
A noção de dispositivo tem, aqui, o sentido que lhe é atribuído por Foucault em História da Sexualidade I: a vontade de saber (1977). Trata-se de um conjunto heterogêneo, formado por elementos discursivos e não discursivos - discursos, instituiçōes, organizaçōes arquitetônicas. Para traçar a história de um dispositivo, é preciso analisar relações. Tais relações devem ser estabelecidas a partir do pressuposto metodológico de que o discurso pode aparecer como um programa de uma instituição, como um elemento que permite justificar ou mascarar uma prática que permanece muda, ou como uma reinterpretação dessa prática, fornecendo acesso a um novo campo de racionalidade.

O dispositivo da anormalidade é um tipo de formação que, num determinado momento histórico, teve como função responder a uma urgência, tendo, portanto, uma função estratégica dominante. É o caso, por exemplo, da absorção de uma massa de população flutuante que uma economia do tipo essencialmente mercantilista considera incômoda: "existe aí um imperativo estratégico funcionando como matriz de um dispositivo, que pouco a pouco tornou-se dispositivo de controle - dominação da loucura, da doença mental, da neurose" (Foucault, 1982:244).

A função estratégica do dispositivo consiste numa manipulação de forças, feita por meio de uma intervenção racional e organizada, seja para desenvolver as relações de forças em determinada direção, seja para bloqueálas, estabilizá-las etc. É, portanto, uma inscrição em um jogo de poder, estando, no entanto, sempre ligada a uma ou a configurações de saber que dele nascem, mas que igualmente o condicionam.

Para tal análise, os saberes não são tomados a partir de sua função de verdade no sentido universal ou geral, mas a partir de sua funçáo estratégica. O que importa para a compreensão do dispositivo é, do ponto de vista da análise dos discursos, a descrição da formação de uma rede de conceitos. Importa focalizar suas inter-relaçōes, ou melhor, as relaçōes de um conceito com outros conceitos de uma mesma teoria ou de teorias diferentes, capazes de delimitar os elementos constitutivos dos saberes e das práticas.

É claro que para esta análise não se pode abandonar as consideraçōes sobre as questões de caráter econômico e social, mas o que constitui o principal foco de atenção nesta pesquisa são dois pontos. Por um lado, os pressupostos teóricos que foram reconhecidos, na época, como constituintes de um embasamento verdadeiro e necessário às práticas psiquiátricas. Por outro lado, as formas assumidas pelas práticas de assistência aos alienados 
então reconhecidas como constituintes do embasamento empírico-experimental para o desenvolvimento de novas teorias e novas práticas, bem como para a instauração de um Estado melhor.

É então, da maior importância levar em consideração a questão levantada por Foucault em $A$ Verdade e as Formas Juridicas (1999), a saber: como se puderam formar domínios de saber a partir de práticas sociais?

Essa questão refere-se à tendência que consiste em procurar de que maneira as condiçóes econômicas de existência podem se refletir e se expressar na consciência dos homens. Tal pressuposto de análise é rejeitado por Foucault, devido à suposição de que o sujeito humano e as próprias formas de conhecimento são dados previamente, e de modo definitivo, e que as condições econômicas, sociais e políticas da existência apenas são depositadas ou impressas nesse sujeito já dado.

O importante nesse estudo é que o interesse de Foucault volta-se para a maneira pela qual as práticas sociais podem chegar a engendrar domínios de saber, os quais não somente fazem aparecer novos objetos, novos conceitos, novas técnicas, mas também fazem nascer formas totalmente novas de sujeitos, de sujeitos de conhecimento e de verdade, que têm, portanto, uma história - suas formas não são definitivas. Por essa razão, ele tenta "mostrar como se pode formar, no século XIX, um certo saber do homem, da individualidade, do indivíduo normal ou anormal, dentro ou fora da regra, saber este que, na verdade, nasceu das práticas sociais, das práticas sociais do controle e da vigilância" (Foucault, 1999:8).

Em relação à análise aqui desenvolvida, não se trata de investigar o conhecimento de uma verdade oposta ao erro, no sentido da cientificidade. Pois, conforme afirma Foucault, "neste nível [da pesquisa arqueológica], a cientificidade não serve de norma: o que tentamos desnudar, nesta história arqueológica, são as práticas discursivas na medida em que dão lugar a um saber e em que este saber adquire o estatuto e o papel de ciência" (Foucault, 1969:249). Portanto, não se procura nenhum conteúdo de verdade que deva ser conferido à loucura e aplicado na prática.

Essa análise do dispositivo da anormalidade aponta mudanças bruscas estabelecidas no discurso psiquiátrico, através das transformaçóes dos conceitos, não para verificar a purificação contínua do saber psiquiátrico, mas para compreender o surgimento de um novo regime nos discursos. Pois funda-se na opinião de Foucault: 
Pareceu-me que em certas formas de saber empirico, como a biologia, a economia política, a psiquiatria, a medicina etc., o ritmo das transformaçōes nāo obedecia aos esquemas suaves e continuistas de desenvolvimento que normalmente se admite. (...) não são simples novas descobertas; é um novo 'regimé no discurso e no saber. (Foucault, 1982:3)

O objetivo desta pesquisa das relaçōes entre os saberes e práticas é fazer com que de tais relaçôes apareçam, numa mesma época ou em épocas diferentes, compatibilidades e incompatibilidades que permitem traçar as diversas configuraçōes históricas do saber psiquiátrico no Brasil. Tal história abandona a visão linear e continuísta da história dos precursores, a fim de delimitar a ruptura que se estabelece em nossa psiquiatria em termos de objeto, de conceito, de método e de estratégia de intervenção.

Ao inserir-se na perspectiva de história dos saberes, esta pesquisa dirige-se aos arquivos, para fazer uma análise de discursos e de documentos. $\mathrm{O}$ material pesquisado constitui-se de tratados, teses, revistas, jornais do período histórico investigado, como, por exemplo, a Gazeta Médica da Babia (1899-1900). Constitui-se, principalmente, de arquivos brasileiros encontrados na Biblioteca Nacional do Rio de Janeiro, nas bibliotecas da Academia de Medicina, do Instituto Histórico e Geográfico Brasileiro, do Instituto de Psiquiatria da Universidade Federal do Estado do Rio de Janeiro, dentre outras. São arquivos de psicotécnica, medicina, neuriatria, psiquiatria e ciências afins, neurologia, medicina legal, higiene militar, higiene mental, arquivos do Manicômio Judiciário. $\mathrm{O}$ conteúdo temático desses arquivos é muito variado: conceitos psiquiátricos, técnicas terapêuticas, notícias sobre a assistência a alienados no Brasil e em outros países, teorias, palestras 'científicas', histórico das formas de assistência, discursos de aniversário ou de inauguração de instituições psiquiátricas, atas de reunióes, legislação sobre a assistência a alienados etc..

Tais discursos serão analisados, como propóe Foucault em $A$ Verdade e as Formas Jurídicas, sem serem tratados como conjuntos de fatos lingüísticos, apesar de existir, segundo ele, uma tradição recente, aceita nas universidades européias, de tratar o discurso como um conjunto de fatos lingüísticos ligados entre si por regras sintáticas de construção.

Há alguns anos foi original e importante dizer e mostrar que o que era feito com a linguagem-poesia, literatura, filosofia, discurso em geral-obedecia a um certo numero de leis ou regularidades internas - as leis e regularidades da linguagem. O caráter lingüístico dos fatos de linguagem foi uma descoberta que teve importância em determinada época. (Foucault, 1999:9)

Porém, ao inspirar-se nas pesquisas realizadas pelos anglo-americanos, o projeto foucaultiano não se dirige a fatos de discurso em seu caráter 
lingüístico, mas como jogos estratégicos, de ação e reação, de pergunta e de resposta, de dominação e de esquiva, de luta. O discurso é, assim, definido como um conjunto regular de fatos lingüísticos em determinado nível, e polêmicos e estratégicos em outro. ${ }^{20}$

Os discursos sāo formaçōes discursivas necessariamente articuladas com as formaçōes não discursivas. As formaçōes discursivas não se oferecem de uma vez, inteiras, como fundamento a partir do qual tudo se apresentaria à análise; ao contrário, a formação discursiva é um processo temporal, que apresenta um certo período de articulaçáo. Segundo Foucault, "uma formação discursiva coloca o princípio de articulaçáo entre uma série de acontecimentos discursivos e outras séries de acontecimentos, transformações, mutações e processos. Não uma forma intemporal, mas um esquema de correspondência entre várias séries temporais" (Foucault, 1969:98-99).

Tal análise dirige-se a um conjunto de enunciados, considerando que não existe um enunciado geral, livre, neutro e independente, mas enunciados que sempre fazem parte de um conjunto; portanto, fazendo sempre parte de uma formação discursiva. Por meio dessa análise, explicitam-se as condiçōes de existência, de surgimento e de transformação de novos saberes, e privilegia-se sua articulaçăo com as práticas institucionais - família, igreja, Justiça, hospital etc. - com os discursos internos das instituiçōes, analisados como uma série de segmentos descontínuos, cuja função tática não é uniforme nem estável.

Esse tipo de investigação permite encontrar práticas específicas, nas quais encontram-se unidades ou categorias discursivas que definem os discursos sobre a loucura como alienação e anormalidade, como discursos his-

${ }^{20}$ Sem dúvida, tal preceito de método converge, no pensamento de Foucault, para a questão da teoria do sujeito, ainda hoje em discussão. A teoria do sujeito, afirma ele, tem sido modificada por certas teorias e por certas práticas, entre as quais se inclui a psicanálise. A psicanálise foi, em sua opinião, a prática e a teoria que reavaliou mais profundamente a prioridade "um tanto sagrada" conferida ao sujeito pelo pensamento ocidental desde Descartes. A psicanálise questionou essa posição absoluta do sujeito como fundamento de todo conhecimento, como aquilo a partir de que a liberdade e a verdade se revelavam. Contudo, no campo da teoria do conhecimento, da epistemologia ou da história das idéias ou história das ciências a teoria do sujeito continua "muito cartesiana e kantiana". A história ainda está presa a esse sujeito de conhecimento, esse sujeito da representação, como ponto de origem a partir do qual o conhecimento é possível e a verdade aparece. Para Foucault, o que importa é "tentar ver como se dá, através da história, a constituição de um sujeito que não é dado definitivamente, que não é aquilo a partir de que a verdade se dá na história, mas de um sujeito que se constitui no interior mesmo da história, e que é a cada instante fundado e refundado pela história. (...) Ora, a meu ver isso é que deve ser feito; a constituição histórica de um sujeito de conhecimento através de um discurso tomado como um conjunto de estratégias que fazem parte das práticas sociais" (Foucault, 1999:9-11). 
toricamente determinados, que constituem um momento específico da prática cotidiana da psiquiatria.

A análise de documentos aqui desenvolvida leva em consideração o fato de que desde que se estruturou a história como disciplina, utilizam-se documentos. Como explica a Arqueologia do Saber (1969), primeiramente interrogando o que querem dizer, se dizem realmente a verdade, em que sentido poderiam pretender fazê-lo, se são sinceros ou falsificadores, bem informados ou ignorantes, autênticos ou alterados. O objetivo, em todo caso, é reconstituir, a partir daquilo que dizem, o passado que já passou e do qual os documentos são provenientes. Nesse caso, o documento é tratado como uma voz reduzida ao silêncio, que deixa traços talvez decifráveis.

Em seguida, a história deixa de interpretá-lo, de tentar determinar se diz a verdade e seu valor de expressão. A pesquisa a ele se dirige de outro modo, organizando-o, recortando-o, distribuindo-o, ordenando-o, repartindo-o em níveis, estabelecendo séries, definindo unidades, descrevendo relaçóes. Nesse caso, o documento não é mais uma matéria inerte através da qual a história tenta reconstituir aquilo que os homens fizeram ou disseram no passado do qual restam traços; não se trata de uma memória, cujas recordações encontram-se nos documentos. Pois a história é o trabalho de uma materialidade documentária (livros, textos, registros, edifícios, técnicas etc.) que apresenta, numa sociedade, formas espontâneas ou organizadas de coisas que remanescem, e das quais a sociedade não se separa.

Enquanto a história tradicional busca memorizar os monumentos do passado, transformá-los em documentos, fazendo falar traços - freqüentemente não verbais -, a história proposta na arqueologia transforma os documentos em monumentos:

A arqueologia busca definir näo os pensamentos, as representaçöes, as imagens, os temas, as
obsessöes que se escondem ou se manifestam nos discursos; mas estes discursos mesmos, estes
discursos enquanto práticas obedecendo a regras. Ela näo trata o discurso como documento,
como signo de outra coisa, como elemento que deveria ser transparente mas cuja opacidade
importuna é freqüentemente necessário atravessar para encontrar, enfim, a profundidade
essencial; ela se dirige ao discurso em seu volume proprio, a titulo de monumento. Ela nāo
é uma disciplina interpretativa; ela näo busca um 'outro discurso' mais bem escondido. Ela
se recusa a ser 'alegórica'. (Foucault, 1969:182)

A opção, aqui feita, pela pesquisa das práticas discursivas, das estruturas institucionais, das disposiçōes regulamentares e das estratégias profissionais pretende ultrapassar a dificuldade de trabalhar, em relação à psiquiatria do final do século XIX e início do XX, com uma documentação sempre filtrada pela interpretação dos psiquiatras. Tal opção não privilegia o ponto 
de vista dos psiquiatras em relação à psiquiatria, mas deixa em suspenso sua versão, na medida em que dela devemos suspeitar, por constituir a racionalidade dominante. Pois a questão aqui analisada - a da descontinuidade histórica na psiquiatria brasileira no início do século XX não diz respeito à racionalidade nem à verdade, mas à articulação do saber com as práticas e seu caráter estratégico. 


\section{Parte I}

A Teuria PEIQUIÁtrica ND BRASIL:

NQVA CONFIGURAÇÃ̃ NAS PRIMEIRAS DÉCADAS DQ SÉCULI XX 
Este livro nasceu de um texto de Borges. Do riso que, com sua

leitura, perturba todas as familiaridades do pensamento - do nosso: daquele que tem nossa idade e nossa geografia -, abalando todas as superficies ordenadas e todos os planos que tornam sensata para nós a profusäo dos seres, fazendo vacilar e inquietando por muito tempo nossa prática milenar do Mesmo e do Outro.

Foucault, Les Mots et les Choses ${ }^{21}$

Desde o momento de sua constituição, no século XIX, até o início do século XX, o saber psiquiátrico brasileiro seguiu a linha da escola francesa de Pinel, introduzida no Brasil principalmente por meio de textos de Esquirol, que serviram de modelo para a criaçáo do nosso primeiro hospício, o Hospício de Pedro II. A partir de 1890, esse modelo começa a ser radicalmente contestado e substituído pela teoria de Kraepelin, traçando uma nova linha na história da psiquiatria. Inauguram-se, assim, modificaçôes radicais no âmbito tanto do saber como no da prática.

${ }^{21}$ É notável o riso de Foucault diante do texto de Borges sobre uma certa enciclopédia chinesa: "os animais se dividem em: a) pertencentes ao Imperador, b) embalsamados, c) aprisionados, porcos de leite, e) sereias, f) fabulosos, $g$ ) cães em liberdade, h) incluídos na presente classificaçāo, i) que se agitam como loucos, j) inumeráveis, $k$ ) desenhados com um pincel muito fino de pêlo de camelo, 1) etc., m) que acabam de quebrar a casca, n) que de longe parecem moscas" (Foucault, 1966:7). 
A passagem do século XIX para o XX é significativa para a história da psiquiatria no Brasil, pois representa uma mudança na atitude dos alienistas brasileiros. Aparece a preocupação em participar da produção cientifica ocidental não mais como meros receptores e repetidores sem rigor teórico situação em que permaneceram durante muito tempo -, mas como pesquisadores de seus fundamentos. As pesquisas inserem-se, então, diretamente nos parâmetros com os quais vinha-se trabalhando na Europa nessa época. ${ }^{22}$

Em meio ao trabalho incipiente dos psiquiatras, que "distraíam-se com a carreira política" (Penafiel, 1913:122), surge a exigência de maior aprofundamento científico; as críticas que vinham sendo feitas já não acrescentavam nada, pois se afastavam totalmente da possibilidade de solucionar as contradiçōes, mesmo em termos práticos, da psiquiatria; aos alienistas já não basta mais justificar a ineficácia dos hospícios com respostas político-administrativas. Era preciso, então, penetrar no interior da 'ciência' da alienação mental.

A partir de Juliano Moreira, a psiquiatria impóe-se como saber necessário à sociedade porque se mostra cada vez mais científica, à medida que tenta derivar seu saber da medicina. A partir do século XIX, a cientificidade do saber médico é exigida e oferecida como uma das bases da política dirigida à conservação da saúde da população concebida como um todo. ${ }^{23} \mathrm{O}$ médico, devido a seu conhecimento das causas sociais da doença, afirma sua função de auxiliar na manutenção do equilíbrio da sociedade. Da mesma forma, a medicina mental atua 'cientificamente' sobre as causas da doença

${ }^{22}$ Em Danação da Norma, ressalta-se que, em meados do século XIX, ocorre uma "importação maciça de teorias, sem grande cuidado com as distinçóes estabelecidas por um mesmo teórico ou com as diferenças entre um pensador e outro, não há nelas uma coerência que possa definir o perfil de um determinado período, algo de original ou uma posição própria em torna da qual se organizem. Caracterizadas pela repetição do saber estrangeiro, onde o que muda é a predominância de um autor sobre os outros, elas retomam certos conflitos teóricos - por exemplo, o da natureza puramente orgânica ou não da doença mental. Retomados e simplificados, trabalhos com pouco rigor, tais conflitos permitem incoerências internas que a prática ausente não pose revestir de aparente objetividade. Por outro lado, as transformaçōes do conceito de alienação mental também não têm maior relevância para o desenvolvimento da prática asilar" (MACHADO, 1978:383).

23 "Possuindo o saber sobre a doença e a saúde dos indivíduos, o médico compreende que a ele deve corresponder um poder capaz de planificar as medidas necessárias à manutençáo da saúde. O conhecimento de uma etiologia social do espaço da sociedade com o objetivo de localizar e transformar objetos e elementos responsáveis pela deterioração do estado de saúde das populaçōes" (MACHADO, 1978:18). 
mental e da anormalidade mental e moral como a delinqüência, o alcoolismo etc., lutando contra a ameaça que os doentes e deficientes mentais constituem para o desenvolvimento moral e econômico da sociedade brasileira.

Por isso, os psiquiatras ressaltam a todo instante o caráter de cientificidade do novo discurso psiquiátrico, com o qual procuram obter respaldo político para a implantação de um novo modelo psiquiátrico, sobretudo no que tange às formas de assistência. ${ }^{24}$

Os psiquiatras brasileiros começam a participar dos debates científicos no estágio em que se encontram na Europa em fins do século XIX, estudando seus novos conceitos e suas novas formas de institucionalização. ${ }^{25}$ No Brasil, como na Europa, os alienistas esforçam-se para escapar ao dilema da causalidade moral ou orgânica, da descrição dos sintomas ou busca de uma sede, para estabelecer uma inteligibilidade escondida da doença em função

${ }^{24} \mathrm{Em}$ discurso comemorativo a Juliano Moreira, Penafiel exalta o programa de reformas que condensava um corpo de idéias logo sancionadas pelos altos poderes da naçáo. Ao caráter social e moral da influência de Juliano Moreira junto ao Estado, Penafiel associa sua importância no âmbito científico e acadêmico; relaciona-o com Oswaldo Cruz, do Instituto de Manguinhos, símbolo da ciência positiva no Brasil. Os dois, juntos, "formaram uma escola à parte: contra as velhas faculdades, que se prendiam aos mesmos programas, mesmos processos de ensino teóricos e nada práticos". Ele afirma que Juliano Moreira introduziu "o exercício prático das experiências e pesquisas anatomopatológicas, bioquímicas, à vida de laboratório, em suma, a modo de sairmos nesse particular, do perfodo em que toda utilizaçāo desses meios se limitara à experimentação na razão proverbial, provocou uma real união de capacidades, refundiu as práticas e o serviço público de assistência" (PENAFIEL, 1913:121).

${ }^{25}$ Os psiquiatras brasileiros começam a participar dos debates científicos sem haver percorrido toda a trajetória de pesquisas, debates e impasses da psiquiatria européia, que vai do critério sintomatológico de classificação e determinação da doença mental até a etiologia, trajetória que conferiu à psiquiatria uma racionalidade cada vez mais médica. Robert Castel resume essa trajetória: "desde a origem, a escola alienista havia elaborado sua concepção reativa e psicogênica da doença mental à distância das pesquisas da medicina clínica. Evidentemente, a distância entre uma 'medicina psicológica' - termo que se torna cada vez mais pejorativo - e uma medicina geral - cada vez mais segura de deter o monopólio da cientificidade - apenas aprofundou-se. (...) Alguns alienistas tentam escapar aos dilemas causas morais-causas orgânicas, descrição dos sintomas-pesquisa da sede, para estabelecer uma inteligibilidade da doença em função de sua evolução e não mais da descrição de seus sintomas. (...) Fazem de cada sintoma um signo que remete, com outros signos, a uma inteligibilidade escondida da doença desdobrada numa duração. Passa-se assim de uma sintomatologia, simples fenomenologia descritiva, a uma semiologia, através da qual a doença adquire ao mesmo tempo um sentido subjacente a suas manifestaçōes exteriores e um potencial evolutivo. Um passo a mais é dado se esta subjacência e essa evolução forem ligadas a uma causa objetiva. É a passagem da semiologia à etiologia, realizada pela concepção de degenerescência de Morel" (CASTEL, 1976:275-276). 
de sua evolução e não mais da descrição de seus sintomas. $\mathrm{O}$ conceito de loucura circular, que faz de cada sintoma um signo que reenvia, com outros signos, a uma inteligibilidade escondida da doença desenvolvida numa duração, permite passar de uma sintomatologia para uma semiologia, pela qual a doença adquire um sentido subjacente e um potencial evolutivo.

Esse sentido subjacente está ligado a uma causa objetiva, passando-se da semiologia para uma etiologia, realizada pela concepção de degenerescência de Morel - que exporei mais tarde -, concepção por meio da qual a inteligibilidade da doença não é mais considerada como dada pelo agrupamento de sintomas, mas por referência a uma causalidade oculta.

As novas questões mais discutidas nos meios psiquiátricos europeus passam, aqui, a ser alvo de atenção: a influência da civilização na produção de doenças mentais, a importância da educação, as degenerescências, os diferentes modos de assistência. Retoma-se o questionamento radical da psiquiatria de Pinel, que havia levado à reformulação da concepção de doença mental, numa tentativa de resolver certas contradições que marcavam a ambigüidade desse saber.

Essas contradiçōes apareciam a todo momento na exigência de definição do conceito de alienação mental como uma doença moral ou física; manifestavam-se na necessidade de explicitar os critérios de cientificidade próprios à teorização da loucura, numa atitude de aceitação ou rejeição do estatuto de ciência para a psiquiatria; elas eram percebidas na prática, no tratamento eminentemente moral, mas que não podia deixar de se referir ao substrato orgânico fornecido pela medicina clínica. Enfim, decorriam da dificuldade de se elaborar a racionalidade da loucura numa linha fisiológica, preocupação que caracteriza o século XIX, entravando a todo instante o discurso psiquiátrico, em sua proposta de institucionalizar e legalizar seu saber, e permitindo aos alienistas enxergarem a fragilidade da teoria psiquiátrica e se voltarem para a pesquisa de novos conceitos. ${ }^{26}$

\footnotetext{
${ }^{26}$ As modificaçōes operadas nos âmbitos do saber e da prática fundam-se num modelo de psiquiatria que caracteriza-se, como ressalta Jurandir Freire Costa, por um tríplice discurso, visto que é formado por três vertentes: a organicista, a psicologista e a sociologista. A corrente organicista atua sobre o organismo doente. Busca uma lesão ou disfunção no nível do organismo somático. Toma por objeto o corpo do indivíduo. Seu espaço de intervenção é o hospital, o asilo, considerado local de cura por meio do confinamento, das terapias biológicas (eletrochoques, choque insulínico, choque cardiológico, lobotomias) e dos medicamentos.
} 
As transformações por que passa a teoria psiquiátrica européia tiveram um paralelo entre nossos alienistas. Sua repercussão no Brasil ocasionou uma reviravolta; gerou a substituição do modelo teórico de Esquirol pela adesão à teoria de Kraepelin. O discurso de nossos alienistas mergulhou num processo de autoquestionamento, que caracterizou a psiquiatria européia do século $\mathrm{XIX}$, passando a discutir as novas teorias psiquiátricas, isto é, questionando um corpo conceitual que se delimita e desenvolve nas primeiras décadas do século XX. Esse novo discurso, chegado a nós sobretudo por intermédio de Juliano Moreira, forma pela primeira vez, no Brasil, um movimento capaz de definir o perfil de uma posição própria, em torno da qual se organizam nossos principais psiquiatras. Essa mudança diferencia o discurso psiquiátrico inaugurado com o modelo alemão dos trabalhos teóricos brasileiros de todo o século XIX, que eram importados sem nenhum cuidado conceitual.

A partir do rompimento com a tradiçăo francesa e da introdução do modelo alemão, a teoria da alienação começa a enfrentar novas dificuldades, apontando diferentes soluções, mais adequadas aos padrōes da ciência da época, na tentativa de resolver a antiga ambigüidade do caráter físico ou moral da doença mental. É assim que, com Juliano Moreira, acredita-se ter resolvido esse problema pelo estreitamento da relação, que sua teoria oferece, com a medicina clínica. Essa relação se manifesta na incorporação de causas psicológicas e morais à etiologia orgânica da doença mental. Se durante o século XIX essa mistura era vista como contraditória e, conseqüentemente, de caráter não científico, agora ela não resultará mais na negação do estatuto de ciência à psiquiatria. Ao contrário, é ela que assegura a vali-

O modelo de doença privilegiado para o estudo da doença mental são a afasia e a paralisia geral progressiva. Essa corrente se prolonga até o final do século XX, tendo tido importantes repercussōes no desenvolvimento da farmacologia. A vertente psicologista representa-se sobretudo pela análise, de onde apreende o modelo da neurose. Tem como objeto de açāo o individuo, por meio da psicoterapia, para atuar sobre a imagem que o doente tem de si próprio. Seu espaço de intervenção é o consultório privado, e seu interlocutor, as familias de elite. Essa vertente exacerbou-se, no século XX, em 'psicanalismo', como o entende Castel, no sentido de uma tendência a estender a psicanálise a toda a sociedade, pensada como dependente de impulsos pessoais. A corrente sociologista assume como seu objeto não o indivíduo, tampouco seu corpo, mas as massas. Seu interlocutor é o Estado, e seu espaço de intervenção, o exterior do hospital. Privilegia como modelo de patologia as doenças venéreas e o alcoolismo. Seu princípio básico é a prevenção da sociedade, realizada por meio de grandes propagandas nas rádios, revistas etc. Prolonga-se até o século XX numa corrente 'sociologista', acreditando ser a doença do indivíduo um reflexo direto da doença da sociedade, que precisa, portanto, ser modificada (CosTA, 1984). 
dade científica do saber sobre a loucura no século XX, na medida em que os distúrbios psíquicos passam a ser definidos segundo a interação do estado psicológico com as condiçōes fisiológicas do indivíduo: "para toda mudança no campo psíquico corresponde um distúrbio no campo somático" (Kraepelin, 1856-1926: introdução).

Dessa forma, estabelece-se uma descontinuidade no saber psiquiátrico, caracterizada pela diferença entre a psiquiatria moral e a psicológica, descontinuidade náo muito clara pelo fato de que a relevância do saber psicológico em Kraepelin não é evidente. Em todo caso, é sempre visível um esforço de adequar a doença mental à etiologia de ordem físico-psicológica e de afastar-se cada vez mais do fato moral, buscando causas específicas em lugar da generalidade etiológica das teorias do século XIX. Kraepelin apresenta em sua nosografia entidades estabelecidas a partir de grupos clínicos determinados, que deveriam "manifestar alguns fatores etiológicos, ou pelo menos algum tipo de lesão suficientemente constante" (Ey, 1975:7).

A psiquiatria passa de um saber eminentemente moral para um saber psicológico: de uma teoria que explica a especificidade das moléstias mentais pelos mesmos fatores genéricos, ou seja, os mesmos aspectos da sociedade civilizada, considerada causa dos diferentes comportamentos desviantes que caracterizam a loucura, para uma psiquiatria em que a especificidade do fator causal vai determinar a especificidade do distúrbio psicológico, fazendo corresponder a cada tipo de doença mental uma lesão específica.

As mudanças no saber psiquiátrico se esboçam nas teorias do século XIX, mas só se evidenciam, no Brasil, com Juliano Moreira, cuja nosografia, que curiosamente não consta de seus escritos, baseia-se na classificação de Kraepelin. Trata-se de uma tentativa de elaboração teórica que, dizendo respeito à especificidade dos distúrbios e de sua etiologia, termina sendo um discurso não só sobre as causas específicas da doença mental propriamente dita, irredutível à ordem disciplinar - em relação à qual o saber psiquiátrico aparece desde o século passado como uma justificativa científica -, mas também sobre as causas das outras formas que escapam ao poder disciplinar. ${ }^{27}$

${ }^{27} \mathrm{O}$ poder disciplinar é o perpétuo trabalho da norma sobre o indivíduo, sujeitando-o à força da disciplina, conforme explica Foucault em Vigiar e Punir. Segundo ele, as disciplinas são técnicas para assegurar a ordenação das multiplicidades humanas e é próprio d̀ disciplinas tentar "definir, em relação às multiplicidades, uma tática de poder que responde a três critérios: tornar o exercício do poder o menos custoso possível (economicamente, pela baixa 
Os psiquiatras classificam então todos os indivíduos considerados irredutíveis à disciplina; classificam o que, no sistema disciplinar do século XIX, era inclassificável, a partir da noção de anormalidade, a qual surge, no final do século passado, como uma categoria médica, relativa a todos os indisciplináveis - os anormais. $O$ conceito da anormalidade como uma forma de psicopatologia surge, então, como uma maneira de justificar em termos médicos as tentativas de submetê-los ao poder disciplinar, viabilizando a inserção da criminalidade e de tudo o que possa a ela estar ligado - suas causas, os meios de curá-la e preveni-la - no domínio do psiquiátrico. Todo indisciplinável, e não só o louco, passa a ser considerado do ponto de vista da doença.

$\mathrm{Na}$ classificação de Kraepelin, as classes nosológicas caracterizam a especificidade etiológica tanto dos diversos tipos de doença mental quanto das várias formas de anormalidade, manifestas sobretudo pelas 'personalidades psicopáticas' (criminosos, instáveis, mentirosos, querelantes), constituindo um importante campo de pesquisa e de argumentaçăo para o saber psiquiátrico. Pode-se afirmar que se deu uma mudança concernente ao saber, marcada pela passagem da concepçăo de doença mental - fundamento da psiquiatria do século XIX - para a concepçăo de anormalidade como forma de psicopatologia, que constitui a novidade do discurso psiquiátrico do século XX.

despesa que acarreta; politicamente, por sua discrição, sua fraca exteriorização, sua relativa invisibilidade, a pequena resistência que suscita); fazer com que os efeitos deste poder social sejam levados a seu máximo de intensidade e estendidos tão longe quanto possivel, sem fracasso nem lacuna; ligar enfim este crescimento econômico do poder e a produçấo dos aparelhos no interior dos quais se exerce (sejam os aparelhos pedagógicos, militares, industriais, médicos), em suma, fazem crescer ao mesmo tempo a docilidade e a utilidade de todos os elementos do sistema" (FoucaulT, 1975:219-220). 


\section{1 \\ Da Doença Mental a Anormalidade}

\section{A Teoria Psiquiátrica no Século XIX}

Os primeiros trabalhos teóricos sobre a alienaçáo mental, que surgiram no Brasil em meados do século XIX, são teses apresentadas às faculdades de medicina do Rio de Janeiro e da Bahia. Essas teses copiam a nosografia aceita na época, numa atitude exclusivamente pedagógica, como um exercício de cunho universitário e burocrático. Elas revelam a ambigüidade do discurso sobre a loucura, característica da psiquiatria européia do século passado, apresentando de modo flagrante a impossibilidade de tornar a loucura objeto para uma racionalidade propriamente médica. Contrapõemse, desse modo, à necessidade de exercer sobre a doença mental uma regulação de caráter moral, inscrevendo-a na categoria das condutas anormais.

Essas teses são uma importação de teorias: retomam certos conflitos teóricos relativos à escola de Esquirol, como o da natureza puramente orgânica ou não da doença mental, sem apresentarem nenhuma coerência que as agrupe de modo a caracterizar uma determinada fase. No contexto do século XIX,

são compreensiveis em seu papel de instrumentos auxiliares de validação da ofensiva médica, tanto no que concerne à consolidaçāo e prestígio do ensino e da profissāo, quanto em relação ao movimento da medicina social que, ao intervir na sociedade, percebe no louco um elemento de desordem e periculosidade urbana e prevê um lugar para sua correção. (Machado et al., 1978:384)

O saber psiquiátrico brasileiro do século XIX é uma repetição da argumentação dos alienistas franceses, apresentada irrefletidamente, sem qualquer vínculo com a prática. As questóes dos métodos de classificação - a natureza da doença mental, sua etiologia, os tipos de terapia mais eficazes 
- são apenas retomadas dos debates europeus e não têm entre nós nenhuma relevância. Todas essas questôes, imanentes à teoria e à prática psiquiátrica, são esquecidas em favor da luta que nossos alienistas travaram para impor a validade de seu saber, para se colocar na sociedade como representantes de uma ciência que deveria ser institucionalizada pelos psiquiatras a fim de desempenhar sua função de recuperação do doente mental.

As teses brasileiras apresentam o mesmo enfoque classificatório de Pinel e Esquirol. A doença mental é descrita a partir dos sintomas, que permitiram sua diferenciação em várias entidades nosográficas, agrupadas segundo os mesmos princípios de classificação das ciências naturais, só que acaba por constituir uma sintomatologia em que se enfatiza o critério de caráter moral. A noçāo de desordem do comportamento, isto é, os atos praticados independentemente da vontade, prevalece sobre a de desordem intelectual; as desordens da inteligência também aparecem no quadro nosográfico, mas deixam de ser fundamentais para a classificação dos distúrbios psíquicos, na medida em que casos de loucura sem delírio também são estudados.

Esquirol define a loucura a partir de uma classificação de monomanias ${ }^{28}$ de três tipos diferentes, de acordo com sua determinação pela inteligência, pela afetividade ou pelo instinto, que se opōem a outras formas de loucura, determinadas pela desrazão, como a demência e a idiotia, formas em que há ausência de inteligência, sendo, portanto, incuráveis. $O$ primeiro tipo de monomania é a intelectual, ou seja, uma lesão parcial da inteligência, que caracteriza uma desordem concentrada num único objetivo ou numa série limitada de objetos, presente no delírio. O segundo tipo é a monomania afetiva, cuja desordem se apresenta no comportamento, sem alterar a inteligência, mas os hábitos, o caráter e as paixōes. $O$ terceiro tipo é a monomania instintiva, ou "monomania sem delírio", que afeta a vontade; a alienação, nesse caso, não é uma desordem intelectual nem moral; o alienado é impulsionado por uma "força irresistível, por arrebatamento que não pode vencer, por um impulso cego, ou uma determinaçăo irrefletida, sem interesses, sem motivos" (Esquirol, 1838, II:803-804).

Em Danaçāo da Norma (Machado, 1978), fica clara a necessidade de analisar a relação entre a loucura, a inteligência e a vontade a partir de Des Maladies Mentales, de Esquirol (1938). Pois Esquirol não a pensa como

${ }^{28}$ Para a classificação das monomanias, ver EsQUIROL. De la monomanie. In: EsQUTrOL, 1838: 792- 834. 
fenômeno homogêneo, nem unitário. As diferentes formas de loucura caracterizam-se ora pelo delírio, como a lipemania, a monomania e a mania, ora pela desrazão, como a demência e a idiotia, formas em que a inteligência é aniquilada, e que são incuráveis. Para Esquirol, quando a loucura não é aniquilamento ou enfraquecimento da inteligência, ela é delírio.

A definição de loucura como delírio estabelece uma relação direta com problemas da inteligência. Porém, delírio não corresponde à inexistência do pensamento, desrazão. $O$ delírio é um distúrbio, uma perturbação, uma desordem da inteligência. A faculdade da inteligência continua existindo ocorrendo rapidez, multiplicidade ou incoerência da idéias -, o que abre a possibilidade de se pensar em reabilitação, transformação, e cura. Não se trata de ausência de pensamento, mas sobretudo de falta de atenção, em presença da razão, mesmo quando o pensamento é desordenado e as relações do eu com o mundo são alteradas.

Com Esquirol, o conceito de delírio parcial dirige-se a um tipo de delírio limitado a um determinado objeto ou grupo de objetos, continuando a inteligência a funcionar normalmente em todas as outra atividades. Daí a importância do conceito de monomania para a transformação da realidade da loucura a partir da psiquiatria, afirma Machado (1978:387-388).

A psiquiatria produz um deslocamento: a inteligência não é mais, a partir de entäo, o referencial bdsico para se aferir a existência ou o grau de loucura. Se encontramos na definição citada de monomania o aspecto do delírio da inteligência e predominância de uma paixão, podemos afirmar que toda sua teoria deixa claro, desde o primeiro momento, que o nivel das paixōes é muito mais fundamental, como característica da alienação mental, do que o da inteligência. Se a loucura implica desordem da sensibilidade, da inteligência ou da vontade, sua característica essencial nāo é ser erro ou ilusão dos sentidos, delirio da inteligência, mas perversão da vontade, que é um fenômeno moral, e não intelectual.

Assim, a loucura é relacionada, em termos de cura e de sintomatologia, ao comportamento moral, mais do que à atividade intelectual e ao delírio. Pois a monomania relaciona-se ao delírio, porém, numa relação menos básica do que sua relação com a vontade - a mais fundamental -, nível em que se situam as paixões que caracterizam o comportamento moral (Machado, 1978).

Se a alienação é sobretudo uma desordem do comportamento, se ela se insurge contra a ordem social por meio de atos involuntários, a cura só pode ser obtida pela imposição de certas normas transmitidas por um processo de reeducação do alienado, de um tratamento moral. De acordo com o princípio de isolamento formulado por Esquirol, a possibilidade de êxito 
nesse tipo de tratamento depende do afastamento do louco num espaço que o separa das causas de sua loucura, inscritas na sociedade e principalmente na família, espaço medicalizado, terapêutico, organizado, sendo ele mesmo instrumento de cura.

Tal princípio foi o que guiou a construção do hospício de alienados no Brasil. Sua formulação encontra-se em textos como 'De la folie' e 'Sur l'isolement des alienés'. As idéias básicas apresentadas em 'De la folie' são as seguintes: " $\mathrm{O}$ isolamento consiste em subtrair o alienado a todos os seus hábitos, afastando-o dos lugares que ele habita, separando-o de sua família, seus amigos, seus servos: cercando-o de estranhos; mudando toda sua maneira de viver" (Esquirol, 1838, I:16), pois é necessário subtrair o alienado de todas as causas que produzem a alienação mental. "O isolamento tem por objetivo modificar a direção viciosa da inteligência e das afecções dos alienados" (Esquirol, 1838, I:16), pois o afastamento do louco permite que se produzam sensaçōes novas que quebram a cadeia viciosa das idéias das quais o alienado não conseguia sair. "Das privaçōes que o isolamento impóe, nascem fenômenos morais preciosos para a cura" (Esquirol, 1838, I:16). Devem ser isolados também "para sua segurança, de seus familiares e da ordem pública" e para "submetê-los a um regime apropriado a seu estado" (Esquirol, 1838, I:16). A arquitetura é um fator importante de cura, pois o que cura é a localização do indivíduo e a própria organização do espaço em que o alienado tem contato com pessoas de seu sexo, sua classe, seu tipo de comportamento.

Teoricamente, a figura do médico deve constituir, por si só, importante fator de recuperação, pela sua capacidade de impor uma ordenação na inteligência, se necessário, e na vontade, ou seja, nos sentimentos do alienado, reorganizando um contato entre o doente e a família por intermédio do hospício.

No tocante às causas da doença, o hospício justifica-se, por isolar o louco da família a fim de romper os hábitos ligados à sua loucura, e no tocante ao tratamento, por possibilitar a intervenção terapêutica, ${ }^{29}$ dadas a sua posição geográfica nos limites da cidade, suas condiçōes de ar puro,

${ }^{29} \mathrm{Na}$ opinião dos autores de Danação da Norma, fica claro que "o princípio de isolamento expressa uma zona de conflito entre a família da época e a psiquiatria: o louco causa, mas acirra e confirma a alienação mental. Trata-se, portanto, de reorganizar o contato entre o doente e a família através do hospício. (...) as despesas e o medo atrapalham a vida familiar. Retirando o peso que a fazia funcionar mal, retirando o perigo que a amedrontava, o objetivo do alienista, enquanto operador de uma transformação, é se colocar como defensor e protetor da família" (MACHADO, 1978:430-431). 
silêncio, tranqüilidade. Ele é "mais uma instituição a quem a política da Medicina Social assinalou um lugar fora do aglomerado urbano" (Machado et al., 1978:432).

Seu projeto de isolamento, no qual o tratamento exclui o doente da vida social, se completa por uma organização interna e pela distribuição dos indivíduos de modo a que a vida do hospício seja regular. Essa distribuição, contudo, embora se dê como uma conseqüência das categorias teóricas, não corresponde à divisão da loucura tal como aparece no quadro nosográfico; seu critério não é nada médico: separa por sexo e por categorias tais como tranqüilos/agitados, sujos/limpos, e outras do gênero.

Com idéias advindas da psiquiatria francesa instituiu-se o hospício no Brasil, por meio do qual a medicina mental se exerceria na prática e na teoria. Mas, a institucionalização do espaço asilar para o louco não favoreceu em nada a pesquisa psiquiátrica científica; os hospícios logo se mostram ineficientes, superpovoados, não medicalizados, e os psiquiatras custam a adquirir autoridade para exercer sua profissão de modo a poder produzir conhecimento científico. Ao contrário do que ocorreu na Europa, o nosso hospício não resulta de um processo intrínseco à ciência, conturbado por grandes debates, que, baseando-se no seu corpo teórico, prescreveu o isolamento do louco, num espaço especial. Nesse espaço o louco seria tratado como acometido por uma doença de tipo especial, não devendo por isso ser acolhido em hospital comum, nem tratado como criminoso nas prisóes.

$\mathrm{Na}$ França, o hospício procurava ser o espaço onde a teoria seria aplicada; além disso, apresentava-se como um rico material para a elaboração científica, suscitando questōes de cunho teórico, de ordem conceitual e de cunho prático. Questōes como o poder político dos psiquiatras e a eficiência da psiquiatria em termos de cura, além de problemas relativos à assistência aos alienados, suscitavam a reflexão constante sobre a realidade asilar, na exigência de novas formulações, a fim de se obter meios de recuperação cada vez mais eficazes. No Brasil, o hospício se encontrava em mãos de uma administração leiga, isto é, não médica, e nele prescindia-se de assistência psiquiátrica, o que causava polêmicas de todo tipo, menos as que pudessem provocar debates dentro do campo da psiquiatria. ${ }^{30}$

${ }^{30}$ Em Os Alienados no Brasil, Teixeira Brandāo (1956) exige mais poder e afirmação do princípio de autoridade médica no Hospício de Pedro II, cujo atraso era atribuído à má gestáo das relaçōes de poder no interior de seu espaço, monopólio do poder e da informação das religiosas 
Dessa forma, a teoria psiquiátrica no Brasil se mantém à margem do processo de autocrítica por que passava na Europa até meados do século XIX. Tal processo intensificava-se com os dados da experiência asilar, por meio dos quais a psiquiatria vinha renovando seus princípios, sempre na tentativa de se posicionar como uma ciência médica, aprofundando seu saber no campo da objetividade científica.

Em História da Loucura, Foucault reduz a importância do saber sobre a loucura, afirmando que "se o personagem médico pode delimitar a loucura, não é porque ele a conhece, é porque ele a domina; e aquilo que para o positivismo será uma figura da objetividade é apenas a outra vertente, a da dominação" (Foucault, 1972:525). ${ }^{31}$

Esse aprofundamento da busca no campo da objetividade científica já se fazia, no decorrer de todo o século XIX, com o estudo das causas da doença mental, por meio de uma etiologia que faria a teoria psiquiátrica penetrar tanto mais nos moldes científicos da época quanto conseguisse ligar o caráter subjacente da doença a causas objetivas, ou seja, orgânicas, atribuindo-as a lesōes físicas.

Os psiquiatras começam a criticar o emprego da pura força física na relação com os alienados por parte dos enfermeiros, e as disputas entre religiosas e enfermeiros contra os médicos, cuja presença junto do louco era ocasional, meramente burocrática, nāo permitindo que o hospício fosse um lugar de conhecimento da loucura e de restabelecimento do doente mental. Como ressalta Alexandre de Carvalho, ao reivindicar, com o advento da República (1890), a criação de um projeto de assistência científico, baseado numa medicina científica, os alienistas conseguiram que o Hospício de Pedro II fosse subordinado à administraçāo pública. Desde 1852, ele funcionava, porém a direçáo da instituiçáo permanecia nas mãos da Santa Casa da Misericórdia do Rio de Janeiro (CARVAlHo, 2000).

${ }^{31}$ Em Uma Trajetória Filosófica: para além do estruturalismo e da hermenêtitica, salienta-se que Foucault analisa o sucesso da psiquiatria, atribuindo maior importância à integridade moral do médico do que ao seu estatuto científico. "Se quiséssemos analisar as estruturas profundas da objetividade no saber e na prática psiquiátrica do século XIX (...), seria necessário, justamente, mostrar que esta objetividade é, na origem, uma classificação de ordem mágica (...). aquilo que chamamos de prática psiquiátrica é uma certa tática moral, contemporânea do final do século XVIII, conservada nos ritos da vida asilar, e recoberta pelos mitos do positivismo" (FouCAULT apud DreYFus \& RABINOW, 1995:11). Salienta-se, ainda, que, para ele, o crescimento do positivismo científico encobre, sob a aparência da objetividade, a explicação do poder de curar, que só se esclareceu mais tarde com Freud. Na opinião de Foucault, tal esclarecimento deve-se a Freud, que explicitou a relação médico-paciente como objeto de ciência, relação considerada fundamental no tratamento das doenças mentais. Contudo, com Freud, o poder e a eficácia do terapeuta foram encobertos pelo mito da cientificidade e a autoridade do psicanalista não surgiu de sua ciência. 
É nesse contexto que a teoria de Morel se desenvolve e marca, a partir do final do século XIX, a elaboraçāo da teoria psiquiátrica.

\section{A Teoria da Degenerescencia}

A passagem do método semiológico de classificaçăo para uma etiologia, ligando a idéia de elemento subjacente e a evolução da doença mental a uma causa objetiva, realiza-se pela concepção de degenerescência de Morel, exposta no Traité des Dégénérescences Physiques..., publicado em 1857, destinado a demonstrar a origem $\mathrm{e}$ a formação das variedades doentias da espécie humana. Segundo Morel, "é impossivel separar o estudo da patogenia das doenças mentais do estudo das causas que produzem as degenerescências fixas e permanentes, cuja presença, no meio da parte sã da população, é um perigo incessante" (Morel, 1857: introdução).

Para ele, a psiquiatria deve agir por meio de uma profilaxia preservativa que combata as causas da doença e previna seus efeitos,

tentando modificar as condiföes intelectuais, flsicas e morais daqueles que, devido a razōes diversas, foram separados do resto dos homens; ela deve, antes de reenvid-los ao meio social, armá-los por assim dizer contra si mesmos a fim de atenuar o número de recidivas. (Morel, 1857:691)

As degenerescências são desvios doentios do tipo normal da humanidade, transmitidos hereditariamente. Elas podem ter causas diversas e, como afirma Robert Castel (1976), o plano do Tratado das Degenerescências de Morel é ordenado em funçāo dessa diversidade: intoxicaçōes diversas, influências do meio social ou da hereditariedade, doenças adquiridas ou congênitas. Quando instalada, a doença segue seu curso e transmite-se a seus descendentes, até a extinção da linhagem.

O programa de profilaxia estudado por Morel abrange a higiene física e moral e dirige-se igualmente ao conjunto social:

Concebemos que o objetivo a ser atingido na aplicą̧āo dos meios terapêuticos e higiênicos está singularmente ampliado. Com efeito, nós näo estamos mais diante de um homem isolado, mas em presenf̧a de uma sociedade, e a potência dos meios da açäo deverá estar em relą̧ão com a importância do objetivo. (Morel, 1857:76-77)

Tal noção de profilaxia está vinculada a um deslocamento operado em relação à concepção teórica da doença mental, que não é mais analisada a partir de uma fenomenologia direta da desordem social. Ao contrário, refere-se ao social, porém aproxima-se, o mais possível, da medicina e de suas 
tendências organicistas. Vemos Morel afirmar: "persegui minha idéia dominante, que era ligar, mais fortemente do que havia sido feito até então, a alienação mental à medicina geral" (Morel, 1857:introdução).

Como ressalta Castel em L'Ordre Psychiatrique, numa discussáo consagrada ao no-restreint, ou seja, à questão prática que coloca em causa a concepção tradicional do tratamento moral, Morel marca o alargamento da definição da doença mental, ao afirmar que escreveu "um livro inteiro para alargar o estudo das causas especiais da alienação, a ele acrescentando o estudo das causas de degenerescências intelectuais, físicas e morais da espécie humana" (Morel, 1860:95). Essa definição ampliada de patologia reforça a relação entre tamanha transformação teórica da doença mental e sua profunda repercussão na prática.

A teoria da degenerescência exerceu uma influência marcante sobre a psiquiatria, no final do século XIX; desde Morel os alienistas brasileiros usaram irrefletidamente o princípio dos estigmas degenerativos. Andrada o ressalta, afirmando que "os alienistas reconhecem facilmente estigmas degenerativos em inocentes disposiçóes anatômicas" (Andrada, 1916:139). O conceito de "estigmas degenerativos" passa a ser abusivamente utilizado, como causa ou como sintoma, ocasionando grande confusão na teoria da alienaçāo mental. É sobretudo nos diagnósticos psiquiátricos que essa confusão aparece. "Esses estigmas que os médicos vêem em toda parte revelam apenas uma estereotipia diagnóstica quando não seja uma simples ecolalia de designação", afirmam Juliano Moreira e Afrânio Peixoto (1955:27).

Somente a partir de Juliano Moreira é que se começa a questionar a função dos estigmas degenerativos na formação da doença mental, que passam então a ser considerados apenas como uma "estereotipia diagnóstica" (Moreira \& Peixoto, 1914:27), e surge um esforço para defini-los claramente. ${ }^{32}$ A teoria das degenerescências torna-se, assim, alvo de estudos por parte de nossos psiquiatras, que a analisarāo com o objetivo de esclarecer a confusāo que dela se originou na psiquiatria brasileira.

As degenerescências são desvios patológicos do tipo normal da humanidade, transmitidos hereditariamente; originam-se por intoxicaçōes diver-

32 Também na Europa os estigmas degenerativos são da maior relevância para o conhecimento científico da alienação: "Os estigmas degenerativos têm valor, em matéria de alienaçáo mental, não como reveladores de causas da loucura, mas como fenômenos precursores de possíveis psicopatias" (MOREL, 1857:introdução). 
sas, por moléstias adquiridas ou congênitas ou por influências do meio social ou da hereditariedade. A evolução própria à doença mental se explicava pela herança da enfermidade que, uma vez instalada, segue seu curso e se transmite à descendência até a extinção da linhagem:

o desvio, por mais simples que o supomos em sua origem, encerra contudo elementos de transmissibilidade de tal natureza, que aquele que traz seu germe torna-se mais e mais incapaz de preencher sua função na humanidade, e que o progresso intelectual já prejudicado em sua pessoa encontra-se ainda ameaçado na de seus descendentes. (Morel, 1857:introdução)

Morel transfere a inteligibilidade da doença mental, antes dada pelo sintoma e pelo signo, para uma causalidade oculta que póe em movimento o processo de evolução da doença, usando esses dois critérios - causalidade e evolução - para a composição do quadro nosográfico dos distúrbios psíquicos. Para ele, é importante conhecer as condiçōes degenerativas, pois "a ciência experimental, como o faz observar este sábio fisiologista, esgota em outras que as infraçóes à lei e a ausência de cultura intelectual trazem na evolução normal do homem psíquico" (Moreira \& Peixoto, 1914:27). Morel as define de modo a abranger as condiçōes exteriores, sociais:

Por outro lado, há uma multidão de circunstancias onde as soluçóes que poderiam dar a filosofia experimental sāo todas encontradas a partir da posiçāo deplorável que as causas degenerativas criam para a espécie humana em determinadas condiçōes (...) admito a degradação original da natureza humana, agindo só ou com o concurso das circunstâncias exteriores, das instituiçôes sociais e de todas as influências ocasionais análogas. (Morel, 1857:introduçāo)

Morel define as degenerescências como desvios da natureza originária do homem, determinando certos estados anormais nas raças:

os desvios [do tipo primitivo] trouxeram variedades, entre as quais umas constituiram raças capazes de se transmitir com um caráter típico especial; outras criaram nas diversas raças elas mesmas estes estados anormais que serāo o objeto especial desses estudos, eque eu designo sob o nome de degenerescências. (Morel, 1857:introdução)

Sua teoria baseia-se na noçăo de desvio do tipo normal, para fundamentar a dicotomia normal-anormal. "Degenerescência e desvio doentio do tipo normal da humanidade sáo, portanto, no meu pensamento uma só e mesma coisa". E, ainda, "As degenerescências só podem então ser resultado de uma influência mórbida, seja de ordem física, seja de ordem moral" (Morel, 1857:introdução). Tal desvio pode ser de origem física ou moral.

A teoria da degenerescência realiza uma transformação radical na concepção de doença mental; ao atribuir sua causa a uma lesão orgânica, desloca 
a racionalidade da loucura de uma psiquiatria social da desordem para o tronco comum da medicina, afastando-se do conceito de doença mental que caracteriza a escola psiquiátrica do século XIX. Contudo, essa mudança não se estende ao método de abordagem da loucura: a nova definição de doença mental não traz, para a psiquiatria, nenhuma modificaçáo quanto à necessidade de ser classificatória. Continua a ser um saber essencialmente nosográfico, só que agora o critério para estabelecer as entidades nosológicas é outro: elas não se determinam mais pelos sintomas de ordem moral, mas a partir de uma causalidade física:

A predisposiçāo, a causa determinante que pōe em jogo esta predisposiçāo, enfim a sucessāo e a transformação dos fenômenos patológicos, que se envolvem e se comandam sucessivamente, determinam por procedimento genético ou patogênico o lugar que deve ocupar o individuo no quadro nosologico. (Morel, 1857: introdução)

O conceito de degenerescência opera essa mudança, primeiramente, ao atribuir a degeneração das células do sistema nervoso à intoxicação; tal degeneração, por sua vez, pode ser causa de doença mental, fazendo com que a clínica médica seja integrante do tratamento da alienação no que diz respeito ao componente fisiológico dos distúrbios mentais.

Em segundo lugar, por meio da concepção de degeneração como um processo fisiológico que atua, ao longo do tempo, sobre o psicológico, tornando, cientificamente, diversos indivíduos mentais sãos suscetíveis de se tornarem alienados, na medida em que apresentam uma anormalidade passível de desencadear esse processo de degeneração, como são consideradas, no século XX, a epilepsia, a sífilis e as intoxicaçóes voluntárias do tipo do alcoolismo, cocainismo, morfinismo etc. Dessa maneira, os distúrbios psíquicos não serão mais considerados apenas do ponto de vista da doença mental propriamente dita, mas estendem-se a todas as anormalidades que podem degenerar em psicopatologia.

A transmissão hereditária será, segundo a concepção de Morel (1857), a característica fundamental da degenerescência, caso em que, em sua opiniāo, a transmissão ocorre em condiçōes bem mais graves do que as que regulam as leis comuns da hereditariedade.

A fundamentação hereditária, com suas tendências organicistas, tem, no início do século XX, grande repercussão sobre psiquiatria brasileira. Privilegia o atavismo, "esse modo particular de herança" (Andrada, 1916:138), freqüentemente utilizado como argumentação da etiologia das enfermida- 
des mentais, ocasionando um aumento de prognósticos pessimistas quanto à recuperação das doenças do cérebro, pois é muito maior o número de incuráveis, no sentido médico, do que o número de reeducáveis. Os diagnósticos passam a acusar uma quantidade de moléstias hereditárias muito superior aos outros tipos.

O conceito de atavismo, explica Juliano Moreira, foi desenvolvido pelos italianos Tanzi e Riva: parte do princípio de que humanidade evolui em direção a um subjetivismo decrescente - o eu subordinado mais e mais ao mundo exterior. A permanência no estado egocêntrico, próprio à infância, seria aquilo que permite definir as degenerescências como uma regressão atávica à ancestralidade, à qual se pode atribuir a razão de muita doença mental ser chamada de 'doamento de atavismo'. "A evolução intelectual na humanidade se faz no sentido de um subjetivismo decrescente, o eu subordinado, assim, mais e mais ao mundo exterior; seria pois atávica essa regressão à ancestralidade egoísta e o paranóico seria um documento de atavismo" (Moreira \& Peixoto, 1914:26).

Seu argumento baseia-se na comparaçáo do desenvolvimento da humanidade ao da criança: "Cada criança que nasce é socialmente comparável ao primeiro homem; o Eu lhe é hipertrofiado, e sem as restriçôes modificadores seria comparável a um louco ou criminoso. É a educação que as submete e modifica, dando-lhes identidade social" (Moreira \& Peixoto, 1914:27).

O enfoque do atavismo, perpassado pela teoria de Morel, torna-se o ponto básico para a concepção da geração de indivíduos degenerados, responsáveis pela alta taxa de criminalidade e pela baixa produtividade da sociedade brasileira em relação aos países mais desenvolvidos. Em 'Assistência aos epilépticos. Colônias para eles', Juliano Moreira ressalta que essa criminalidade é uma revelaçáo sintomática da epilepsia, que "fornece um vasto contingente à legião de criminosos de todas as classes (...) deve-se atentar também para os epilépticos estrangeiros que vêm tentar a sorte e que caem no alcoolismo e no crime" (Moreira, 1905a:167).

Vistos nesse contexto, os epiléticos, os alcoólatras e os sifilíticos, que não são doentes mentais propriamente ditos, são considerados um entrave para o progresso; eles representam um grande risco para a ordem social, na medida em que durante as crises são improdutivos, atentam contra a disciplina e concorrem para a transmissão de seu mal a seus descendentes, gerando "maus filhos, para infortúnio do nosso futuro" (Moreira, 1905a:167). 
A saúde mental passa a ser estudada no contexto social. A teoria da degenerescência e o atavismo abrem o discurso da psiquiatria para um novo campo de pesquisa: os degenerados de toda espécie, mesmo não alienados, para os quais deve-se montar um amplo sistema assistencial. A teoria psiquiátrica se alarga, lançando-se ao mesmo tempo no saber da medicina geral, devido a suas tendências organicistas, e no saber sociogenético, ao estabelecer novos fundamentos para a relação entre doença mental e sociedade: a saúde mental se torna "um problema que concerne ao estudo dos fatores de desenvolvimento físico e intelectual das raças" (Moreira, 1899-1900:112).

Em 'A sífilis como fator de degeneração', Juliano Moreira a estuda em sua relação com a sociedade, ao lembrar os perigos individuais, hereditários e sociais que derivam da sífilis: "Os grupos humanos que se interessam pela própria conservação não descuram ponderar aprofundadamente os motivos que os podem aniquilar" (Moreira, 1900:112). Como os perigos são importantes, ao apontá-los, Juliano Moreira exprime a ineficiência ou o desinteresse dos poderes públicos quanto aos problemas médicos em discussão: "Dos poderes públicos não há que esperar entre nós reformas que atinjam os perigos sociais; é da propaganda dos médicos, que poderá resultar algum proveito para o grupo humano" (Moreira, 1900:112).

A preocupação com o conceito de degenerescência opera modificaçóes no corpo teórico, agora diante da necessidade de definir novas enfermidades e posicioná-las de acordo com o quadro nosográfico. A epilepsia, por exemplo, é retomada; passa a ser analisada como um conceito da patologia psiquiátrica:

A concep̧ão de epilepsia passa atualmente, como a bisteria, por um processo revisor, cuja extensão é impossivel prever. Em todo caso, sempre há de ficar um grande grupo de degenerados, em que as reą̧ōes convulsivas são apenas um modo de descarga nervosa, podendo alternar com outros modos psiquicos de exteriorizạ̧ăo doentia. (Moreira, 1912b:315)

Esse conceito de cunho patológico resulta do enfoque sociogenético ${ }^{33}$ na racionalidade médica do discurso psiquiátrico sobre os perigos sociais

\footnotetext{
${ }^{33}$ Segundo Birman, a sociogênese da doença mental é a formulação de uma hipótese presente no discurso psiquiárrico para explicar a relação entre o crescimento da população de alienados mentais e o desenvolvimento da sociedade. A hipótese é: "Existiria uma relação causal entre o processo de desenvolvimento material e o surgimento da alienação mental, sua difusão e a diversificação de suas formas. Como conseqüência desta hipótese, a sociedade industrial seria a responsável pela difusão da intensificação da loucura. Ela permitiria um desenvolvimento das paixões, exporia as individualidades a um maior limiar de frustração, produzindo assim a alienaçăo em larga escala" (Birman, 1978:224-225).
} 
que devem ser assistidos com muito empenho: "A assistência e essas pessoas [aos epiléticos] impóe-se à sociedade como uma medida altamente eficaz e por isso mesmo digna de ser efetuada com a energia que ela costuma despender com a própria conservação e para debelar os perigos sociais" (Moreira, 1912a:315).

\section{O caráter social do conceito de hereditariedade faz o combate à} mestiçagem aparecer sob uma roupagem de cientificidade. A mestiçagem será considerada negativa para a composição de uma sociedade civilizada em que os padrōes de progresso não devem ser ameaçados pela geração de individuos suscetlveis de degeneração física e moral, conseqüência da união de raças diferentes, que ao se cruzarem os transmitem à descendência, formando 'raças mais fracas'. Essas idéias são propugnadas pelos psiquiatras da Liga Brasileira de Higiene Mental, ${ }^{34}$ que tomaram o modelo conceitual organicista para fundamentar a proposta preventiva da psiquiatria do século $\mathrm{XX}^{35}$

${ }^{34}$ Fundada em 1923 pelo psiquiatra Gustavo Riedel, a Liga Brasileira de Higiene Mental tinha o objetivo de melhorar a assistência aos doentes mentais. A partir de 1923, os psiquiatras da Liga começaram a elaborar projetos que visavam à prevenção, ̀̀ eugenia e à educação dos individuos 'normais', inclusive por meio de uma açāo terapêutica que deveria exercer-se no período pré-patogênico, isto é, antes do aparecimento dos sinais clínicos da doença mental. De acordo com Alexandre de Carvalho (2000), a higiene mental, como campo de saber e de práticas, nasceu nos Estados Unidos em 1908; no Brasil, os psiquiatras da Liga foram apontados como grandes dirigentes das primeiras campanhas em favor da profilaxia mental. Segundo Alexandre de Carvalho (2000) e de acordo com diversos autores (CosTA, 1976; AMARANTE, 1983, 1994; ENGEL, 1993, 1995; Reis (2000); AmaranTE et al., 1995, a Liga Brasileira de Higiene Mental foi a instituição mais expressiva da psiquiatria higienista.

${ }^{35}$ De acordo com REIS (2000), costuma-se admitir que a eugenia foi formulada primeiramente pelo inglês Francis Galton, na segunda metade do século XIX. Darwinista e estudioso da hereditariedade, ele a considerava uma "ciência do melhoramento do patrimônio hereditário"; essa ciência atribuía "às linhagens mais adaptadas ou mais bem dotadas mais oportunidade em relação aquelas que o são menos" (DARMON apud REIs, 2000:166). Reis explica que, nessa época, difundia-se, na Europa, um temor ao "suicídio da raça" ou à "degenerescência da raça", decorrente do pressuposto de que os indivíduos das ditas "raças superiores", abstendo-se deliberadamente de procriar, apresentavam uma taxa de reprodução muito baixa. Esse quadro se agravava ainda mais devido ao fato de que, com o progresso da civilização, protegiam-se cada vez mais, por humanitarismo e filantropia "contra-seletiva" no dizer dos eugenistas, os doentes físicos e mentais - além daquela espécie de degenerado tipicamente moral -, que de outra forma deveriam desaparecer, ou seja, por seleção natural, rebaixando-se, assim, o nível geral da espécie (Roll-HaNSENS apud ReIs, 2000:166). De acordo com Stepan (apud ReIS, 2000), no caso brasileiro, os primeiros esforços sistemáticos de eugenia ocorreram em 1918, com a fundação, por iniciativa de Renato Kehl, da Sociedade Eugênica de São Paulo, que reunia a maioria da elite médica dessa cidade. Contava com 140 membros, sendo seu presidente Arnaldo Vieira de Carvalho, diretor da Faculdade de Medicina de São Paulo. Embora tendo 
De acordo com Elso Arruda (1959), a higiene mental é, então, considerada uma ciência, uma disciplina positiva, normativa e aplicada. Positiva, porque tem por objetivo a manutenção da saúde mental e a prevenção dos distúrbios psíquicos. É normativa porque, para alcançar seu objetivo, sujeita-se a normas indispensáveis, ou as prescreve. É aplicada, porque seus princípios podem ser aplicados aos mais diferentes setores da atividade humana, objetivando uma existência sadia e a felicidade individual e coletiva. $O$ setor profissional é um deles.

A saúde mental é compreendida como a "expressão completa e livre de todas as potencialidades do indivíduo em recíproca harmonia, objetivando ideais, aspiraçóes e propósitos de sua personalidade" (Hadfield apud Arruda, 1959:61). A essa característica acresce-se o fator de adaptação biológica e social do indivíduo.

Segundo Cunha Lopes (1940), a higiene mental abrange todos os círculos da atividade humana. Do ponto de vista biológico, o homem é um animal racional e pensante, é por excelência dotado de atividade do cérebro. Por isso mostra-se tão suscetível às vicissitudes que incidem sobre seu cérebro. A higiene mental assume um duplo papel: conservar a saúde psíquica e prevenir as doenças do cérebro.

Em sua opinião, Juliano Moreira já previa, em 1906, a época da higiene profilática. Em carta enviada do Egito aos Arquivos Brasileiros de Psiquiatria (1907), Juliano Moreira escreve:

as questōes de herança, seus complexos pormenores, as relativas ao alcoolismo è à sifilis, ditarão por certo as normas principais das moléstias mentais e não somente destas, das nervosas em geral também, porque sobre as fraquezas do sistema nervoso germina a loucura e se iniciam as regressóes mais ou menos rápidas da famillia (...) É claro portanto que é tempo de diminuir o número de alienados. É evidente que näo podemos nutrir a esperança de uma vitória decisiva a curto prazo, mas aqui, como já ocorre a outras moléstias bumanas, em breve surgirá a época da higiene profilática. (Moreira apud Cunha Lopes, 1940:235) ${ }^{36}$

contado com uma recepção bastante favorável nos meios médicos e na imprensa, a Sociedade Eugênica não conseguiu sobreviver à morte de seu presidente e à ida de Renato Kehl para o Rio de Janeiro em 1919.

${ }^{36}$ Cunha Lopes descreve a campanha pela eugenia, realizada em 1917, por meio da imprensa, que resultou na constituição da Comissāo Central Brasileira de Eugenia. Seus objetivos eram: a) manter no país o interesse pelo estudo das questōes de hereditariedade e eugenia; b) propugnar a difusão dos ideais de regeneraçāo física, psíquica e moral do homem; c) prestigiar ou auxiliar, ad libitum, toda organização científica ou humanitária de caráter eugênico. Juliano 
Com o movimento dito científico iniciado no Brasil por Juliano Moreira, esse problema é debatido e retomado na sua origem, tornando relativo o alcance do conceito de hereditariedade, sobretudo do atavismo. Até então, a mestiçagem $\mathrm{e}$ a hereditariedade vinham sendo consideradas únicas fontes de quase todos os desvios mentais, na medida em que se constituíam como principal causa de degeneração.

Juliano Moreira estuda a causa da degeneração associando-a diretamente ao problema do alcoolismo, à higiene, à alimentação e à moralização das massas, com a qual a medicina mental deve colaborar para cuidar "destas classes desprovidas que apenas entrevêem o movimento ascendente das classes superiores e não podem alcançá-lo se são abandonadas a suas próprias forças" (Morel, 1857:687).

Com base nessa noção de moralizaçăo das massas, Juliano Moreira analisa o problema dos negros africanos alcoolizados. Afirma que "o álcool infiltrava nos neurônios os elementos degenerativos que, reforçados através dos tempos, dáo razăo de ser de muita tara atual, atribuída à raça e à mestiçagem por todos aqueles que não se querem dar ao trabalho de aprofundar as origens dos fatos". E, ainda, que "a má natureza dos elementos formadores de nossa nacio-

Moreira argumenta em favor da eugenia: "O Brasil está destinado, como país de imigração, a ser o rebotalho movediço (...) seremos o refúgio dos piores imigrantes. $\mathrm{Da}$ análise de nossas estatísticas manicomiais e criminais pode o observador atento concluir que a emigração nāo desejável (dos norte-americanos) é a que constitui o principal fator de aumento de alienados e delinqüentes em nossos manicômios e prisōes. O número de delinqüentes europeus escapados à punição de seu país é entre nós muito maior que à primeira vista parece. (...) Da má qualidade das gentes que desde os tempos da primitiva colonização têm se incorporado ao nosso povo dependem, por força de herança e más condiçōes de educação, muitos defeitos de nossa população atribuidos a mestiçagens e quejandos absurdos" (MOREira apud LOPES, 1940:6). O objetivo da eugenia, comenta Cunha Lopes, é aumentar a descendência de casais geno e fenotipicamente sadios e de promover casamentos favoráveis sob esse mesmo ponto de vista; procurar limitar o quanto possível a descendência de anormais e restringir a multiplicaçáo de indivíduos hereditariamente inferiores. "As medidas que decorrem da eugenia, afirma ele, dependem do esforço das elites e da educação e cultura das massas populares" (LOPEs, 1940:7-8). Em sua opiniāo, há dois tipos de cugenia. A positiva, feita por meio da propaganda que esclarece e aconselha, enaltecendo qualidades básicas universalmente aceitas - inteligência, boa saúde, relativa imunidade para doenças, certos traços de caráter (coragem, domínio sobre si mesmo, bondade, tolerância, iniciativa, confiança, honestidade etc.): "O que importa portanto é intensificar a educação popular, ensinado quais são as boas qualidades tradicionais da espécie humana". A eugenia negativa é a interdição de casamento entre raças muito diferentes com base no conceito biológico dos cruzamentos. "Cruzamento de raças próximas costuma dar bons resultados no tocante ao físico e também para o lado psíquico, ao passo que a mistura de raças mui diversas entre si dá resultados desfavoráveis" (LOPES, 1940:7-8). 
nalidade deve-se à vasta degenerescência física, moral e social que injustamente tem sido atribuída ao único fato da mestiçagem" (Moreira, 1955:65).

As degenerescências passam a ser estudadas como algo determinado pela predisposição do indivíduo a esse processo hereditário, agora compreensível somente no âmbito moral. Juliano Moreira cita o caso de um mestiço querelante, filho de pai italiano alcoólatra e de uma preta normal, para contrariar a opinião de Nina Rodrigues, que nele viu mais uma prova da mestiçagem como fator de degeneração. A questão da mestiçagem como fator degenerativo é associada àquilo que Juliano Moreira considera, em psiquiatria, um "capítulo de alto interesse social e jurídico" - o chamado "processomania" (Moreira, 1908b:426). Em sua opiniāo, trata-se de um problema de classificação dos indivíduos afetados de 'processomania' como pertencentes a um só ou a diversos grupos psicopáticos. Estando Juliano Moreira na Itália, aproveitou para fazer um levantamento sobre o estado mental dos parentes não mestiços do doente, observando um grande número de doenças mentais na família - imbecilidade, epilepsia etc. Todos os parentes eram intelectualmente inferiores ao doente em questão. A superioridade intelectual do querelante seria, portanto, resultante não da mestiçagem, mas da circunstância de ser a mãe uma mulher sā (Moreira, 1908b).

As degenerescências que atuam sobre o desenvolvimento mental não podem ser atribuídas à herança e à mestiçagem. Elas devem ser determinadas pela predisposição do indivíduo ao processo hereditário. A predisposição, "uma determinada constituição emotiva bem definida por Dupré" (Moreira, 1918:322), é um conceito que surge a partir da associação do tipo sociológico ao âmbito da moralidade, da teoria da degenerescência. A educação vai agir sobre a constituição do indivíduo, transformando-o ou não em doente mental.

Quanto ao que haviamos exposto resulta que a vários grupos de individuos deve-se atribuir uma maior ou menor capacidade de resistência às causas nocivas em relação a sua predisposiçāo comum, e que esses sāo, de acordo com suas tendências especiais e de suas especiais condiçōes de vida, expostos a um número maior ou menor de perigos, de pontos de vista análogos, que permitiräo elaborar um conceito da dupla natureza daquelas multiformes causas mórbidas que costumam ser reunidas sob o nome de predisposiçāo pessoal. (Kraepelin, 1926, introduçāo)

Assim, Kraepelin analisa a predisposição pessoal de acordo com as condições de vida e tendências especiais do indivíduo, cuja definição, levada a um plano mais restrito, será explicitada na conclusão de Juliano Moreira a respeito dos distúrbios psíquicos nos leprosos: 
Não se pode negar que as toxinas leprosas, atuando sobre os neurônios superiores de um individuo predisposto, possam produzir psicoses infectuosas. Além disso, as complica̧̧öes habituais de lepra (tuberculose, estreptococia etc.) quantas vezes explicaräo o aparecimento de tais psicoses? O estado mental varia muito com os precedentes de heranf̧a e da educaf̧āo de cada um deles. (Moreira, 1908b:426)

Essa resposta a Hansen é elucidativa, porque apresenta uma confirmação taxativa, obtida em uma pesquisa objetiva sobre as psicoses em leprosos, do papel da predisposição como origem dos distúrbios mentais. Ela constitui o veículo da degenerescência potencializado pela herança e pela educação.

Pois, a partir de seus estudos sobre o estado mental dos leprosos e sobre as várias modalidades da lepra, Juliano Moreira afirma primeiramente que não há uma forma de psicose particular à infecção leprosa; em segundo lugar, que, coincidindo com a lepra, observa-se, eventualmente, a maior parte das formas conhecidas de alienação mental; em terceiro lugar, que as complicações habituais da lepra podem ser causas do aparecimento de psicoses em leprosos; finalmente, que o estado mental varia muito com os precedentes de herança e educação de cada um deles.

E considerada determinante a relação da maneira pela qual a lepra é aceita pelo leproso com sua educação, com seu meio social. Aqueles que vêm de meios sociais mais altos têm mais dificuldade em aceitar a doença $e$ a repugnância por ela provocada, enquanto os camponeses mais incultos não importando as diferenças étnicas - aceitam muito bem a sua desfiguração (Moreira, 1908b:426).

A remissāo da predisposição à questão da educação decorre portanto desse deslocamento do conceito de degenerescência física para o plano social, que tem por consequiência o abandono do conceito de herança atávica, agora vista como uma mera fantasia, visto que é concebida "só no sentido sociológico, e estendido ao conjunto de condições físicas e sociais do ambiente, originárias ou conseqüentes que nos influenciam em nossa derivaçāo mesma" (Moreira \& Peixoto, 1914:27).

Contudo, o conceito de atavismo não foi de todo abandonado pela teoria psiquiátrica brasileira. O próprio Juliano Moreira, que o rejeita para a etiologia dos distúrbios psíquicos, não nega que o processo mental se dirija a uma submissão progressiva do eu ao meio social, mas posiciona-se claramente contra a idéia de um altruísmo somático, violado na doença mental - principal fundamento da concepção atávica. Essa idéia passa a ser considerada um conceito vazio, pois o altruísmo também se definirá em sentido sociológico; será 
entendido como uma espécie de contrato a que a humanidade se submete. $\mathrm{O}$ egocentrismo exagerado dos degenerados deve ser atribuído a uma causalidade moral, isto é, aos defeitos de educaçăo que, somados à predisposição, formam a estrutura do indivíduo: "O altruísmo não é uma aquisição somática, é apenas uma espécie de contrato a que nos submetemos tacitamente ao partilharmos a vida social" (Moreira \& Peixoto, 1914:27).

Curiosamente, à proporção que o discurso psiquiátrico se aproxima da clínica médica, por meio do substrato físico oferecido pela teria da degenerescência, cresce seu envolvimento com a origem moral, recaindo inclusive em discussōes sobre a educação que, longe de ser deixada para trás como poderia parecer aos olhos dos defensores das teorias organicistas em psiquiatria, ganha força, tornando-se foco de preocupaçāo de grande parte dos alienistas. O problema da educaçāo enfoca tanto a criança como uma medida preventiva contra a possibilidade de a civilização exercer influências negativas a sua saúde mental, quanto o degenerado, como uma medida terapêutica de reeducação por meio do tratamento moral.

Abre-se assim um espaço para a retomada de questōes relativas à civilização e aos problemas do meio urbano encarado como nocivo e insalubre, que datam do século XVIII, quando os filósofos e economistas transformam a imoralidade e o artificialismo urbano em causas de alienação mental. ${ }^{37}$ Essas questóes foram tratadas pelo discurso psiquiátrico no século XIX, e no Brasil especificamente a partir de Juliano Moreira, que lhes atribui uma significação médica, analisando-as com o enfoque etiológico e ao procurarlhes uma profilaxia. A má educação proveniente de uma sociedade civilizada é responsável pelo potencial dos distúrbios psíquicos no indivíduo e até, em um nível mais genérico, pela formação de uma raça de degenerados.

\footnotetext{
${ }^{37}$ Como explica Birman, a temática da cidade em vias de industrialização produzia riquezas $\mathrm{e}$ necessidades artificiais se desenvolveu durante todo o século XVIII. A questão é: se o processo de estimulação artificial das necessidades acelerava o desenvolvimento da produção, ela traria como seu corolário a 'imoralidade' dos costumes. Essa idéia, formulada pelos filósofos e economistas, torna-se uma temática médica a partir do final do século XVIII e início do XIX. A imoralidade e o artificialismo da existência transformam-se em causas de alienação mental. Birman cita a relação estabelecida por Esquirol entre a civilização e a etiologia do suicídio e da alienação mental. Refere-se, ainda, à articulação do efeito degradante do processo de industrialização e da divisão do trabalho no indivíduo (o parcelamento da atividade humana - desenvolvimento de algumas atividades e atrofia de outras, levando à degenerescência individual) e, visto numa perspectiva mais ampla, no conjunto dos indivíduos, formando uma "raça de degradados" (BIRMAN, 1978: 200-203).
} 
Essa temática aparece nos textos psiquiátricos brasileiros, bastante freqüentemente, já dentro de uma visão terapêutica que contudo se demonstra confusa, onde a dualidade clínica e moralidade permanece, ao invés de se resolver.

Todo apóstolo das causas humanas, ainda que no dominio cientifico, há que possuir as bases morais serenas e estáveis (...) Tudo isso ${ }^{38}$ tem pouca importância social em comparação com a beleza moral que envolveu a alma do alienado, que vive com doçura, assistido na clínica, (...) trabalhando pela verdade e pela brandura, isto é, por todos os elementos efetivos do progresso, naquilo que a civilizaçāo conta como um dos acontecimentos mais caros, isto é, a vida do alienado. (Moreira \& Austregésilo, 1923:55)

Para efeito de análise da novidade que o início do século XX representa para a psiquiatria no Brasil, o que vai interessar dessa temática é que a teoria das degenerescências com as antigas visōes sobre a civilização, acrescidas do novo conceito de hereditariedade, fundamenta o enfoque organicista e sociogenético da nosografia alemã, cuja etiologia fornece o acoplamento dos elementos de origem orgânica e social com o estado psicológico manifestos na evolução do processo mental.

Todos esses princípios desenvolveram-se lentamente durante o século XIX, dando forma a um novo corpo teórico. A nova concepção de doença mental a define "como desvio da normalidade que é, uma exceção biológica" (Moreira, 1919:93); a definição do estado mental por meio da relação intrínseca entre a sobrevivência física e psicológica do homem originário e o meio social ao qual deve se adaptar, pois "[o egoísmo originário da criança] é indispensável à manutenção da vida nesta fase, e de tal forma que constitui uma verdadeira necessidade biológica" (Moreira \& Peixoto, 1914:30).

Com base em um novo corpo teórico e por meio do conceito de herança, o saber psiquiátrico alarga o seu domínio, estendendo-o a toda a população, doente em potencial, na medida em que não estiver moral e organicamente preparada para resistir à contradição subjetividade originária versus meio social. Nessa perspectiva, ao entrar em choque com uma educação inadequada, o meio social origina o indivíduo anormal no sentido de degenerado. O degenerado - epilético, alcoólatra, sifilítico -, mesmo não alienado, passa a ser objeto da psiquiatria, que não mais está restrita ao alienado, mas atinge a todos aqueles que podem representar um risco de desor-

38 'Tudo isso' refere-se aos feitos de Juliano Moreira, enaltecido por ter aplicado as idéias de Pinel e as de Kraepelin, dando aos hospícios o aspecto de hospitais comuns e por ter sido o introdutor da verdadeira concepçāo de paranóia no Brasil. 
dem para a norma social. A psiquiatria amplia dessa forma seu campo de intervenção, estabelecendo uma diferença fundamental entre os casos de doença mental e os de degenerescência moral.

A partir da concepção de degenerescência, da idéia de que os sintomas psiquiátricos teriam como causa uma lesão originária que se expandiria até degenerar o sistema nervoso, surge um novo objeto para o conhecimento da psiquiatria - o degenerado. Sua principal característica é definida pela potencialidade da doença mental, na medida em que a epilepsia, o alcoolismo e a sífilis poderiam desencadear a qualquer momento o processo degenerativo e, portanto, poderiam terminar por produzir lesóes neurológicas responsáveis pelos distúrbios mentais: "Ora, o degenerado hereditário ou adquirido, pela miopragia do seu sistema nervoso, está predisposto para as auto ou heterotoxicoses que despertam as tendências delirantes, as síndromes" (Moreira, 1912b:315).

A noção da degenerescência justifica teoricamente a difusão do saber psiquiátrico por todo o campo da anormalidade, à qual a psiquiatria liga a doença mental, na medida em que o degenerado traz desde a infância como estigma os restos da loucura dos pais.

O campo da anormalidade constitui-se, no século XIX, quando surge esse conceito como uma categoria médica. ${ }^{39}$ No Brasil, só vai se tornar objeto do saber e da prática psiquiátricos com Juliano Moreira, que inicia estudos sobre a epilepsia, o alcoolismo e a sífilis como causas possíveis de posteriores delírios, que levariam à loucura e, sobretudo, como causas atuais de delinqüência e criminalidade. Ele elabora um sistema de assistência psiqui-

\footnotetext{
${ }^{39}$ Marcio Alves da Fonseca (2000) aponta o projeto de Foucault de estudar as diferentes figuras históricas que permitiram a formação do conceito de anormalidade no pensamento médicosocial do Ocidente, a partir do curso do Collège de France 'Les anormaux', ainda inédito. Foucault mostra como "a grande família indefinida e confusa dos anormais", do final do século XIX foi formada em correlação com um conjunto de instituições de controle e de mecanismos de vigilância. Ele estuda como o grupo 'anormais' se formou a partir de três figuras históricas: o monstro humano, os incorrigíveis e o onanista. O monstro, por exemplo, constitui exceçāo em relaçāo à forma da espécie, mas também às regularidades jurídicas e às leis da sociedade. No curso 'Il faut défendre la société', ele continua esses estudos fazendo ver implicaçōes entre o direito e a norma, ao apontar uma nova noção de normalização, cada vez mais centrada, numa biopolítica, em mecanismos de atuação sobre a vida, sobre os processos biológicos do homem como espécie. Tais mecanismos asseguram uma disciplina do corpo e uma regularização da população. A norma os articula. As sociedades de normalizaçáo são sociedades em se cruzam a norma de disciplina e a norma de população.
} 
átrica dirigido também para a questão da delinqüência e da criminalidade, ao contrário da psiquiatria precedente, que, durante todo o século XIX, volta seu saber somente para a doença mental.

A noção médica de doença como desvio da normalidade, compreendida como exceção biológica, introduz-se na teoria psiquiátrica, fazendo corresponder o desvio moral, ou seja, a anormalidade moral à anormalidade psicológica, considerando-o resultado de uma exceçáo, isto é, de um déficit na formação do psiquismo do indivíduo. A anormalidade constituir-se-á como objeto da teoria psiquiátrica, por ser compreendida, do mesmo modo que a doença mental, ${ }^{40}$ como uma deficiência, uma regres-

${ }^{40}$ Ey (1975:1) explicita: "A vida psíquica aparece como um progresso e a doença mental como uma regressāo. É nesse sentido que a doença se revela entāo, ao mesmo tempo, como déficit de organização progressiva do ser e como um modo regressivo de existência". Henri Ey é considerado autoridade máxima da psiquiatria francesa e um dos clínicos mais notáveis em âmbito internacional. Ey (apud GARCIA, 1995) critica os movimentos dos anos 70 do século XX, que ele impropriamente qualifica de antipsiquiátricos. Para Ey, a questáo da doença mental deve ser tratada pela psiquiatria, um dos ramos da medicina aplicada à profilaxia e à terapêutica, conferindo-lhe um caráter exclusivamente médico. Contudo, como enfatiza Ramón García (1995), é evidente que a psiquiatria e seus congressos sempre tiveram como objeto os psiquiatras, seu prestígio, sua carreira e em nenhum caso os enfermos e sua condição; e para esses últimos, a única resposta dada foi a do manicômio, "triste herança nossa" (GARCla, 1995:171). A história da psiquiatria é, pois, para García, apenas a dos psiquiatras, e sua defesa tem um caráter explicitamente corporativo. Os excessos de privilégio são defendidos em função própria sobrevivência dos psiquiatras, que chegam inclusive a solicitar a formação de comitês de saúde pública sob a sua tutela. Ey ressalta que a Associação Mundial de Psiquiatria condena o uso político que pode ser feito dos conceitos, dos métodos e das instituiçōes próprios ao exercício da psiquiatria e ao serviço exclusivo de atendimento dos doentes mentais. De acordo com Ramón García, tal posição de Ey lembra aquela que os psiquiatras franceses emitiram em novembro de 1929 como resposta aos ataques do movimento surrealista. O Dr. Clérambault, ao final de uma famosa reuniāo na Société des Annales Médicaux de Psychologie, recorre d̀ opiniōes de outros grandes psiquiatras, Jante e Abely, para concluir que: "Haveis mostrado que existe uma campanha de difamaçāo. Este ponto merece ser comentado. A difamaçāo constitui parte dos riscos profissionais do alienista. Ataca-nos em certas ocasiōes e precisamente em relação a nossa funçáo administrativa e nosso poder de especialistas. É justo que a autoridade, que nos delega, nos proteja (...); contra os riscos profissionais de qualquer natureza, é necessário que os técnicos estejam garantidos por disposiçôes precisas que nos assegurem contra os danos esporádicos ou permanentes. Tais danos não são unicamente de ordem material, mas também de ordem moral. A proteção contra estes perigos deveria comportar socorros, subsidios, indenizaçōes e, finalmente, pensōes completas e permanentes. $O$ risco da assistência poderia ser coberto, em casos urgentes, por seguros de mutuários; porém, última instância, a indenização de tais danos deveria ser encargo da própria autoridade, ao serviço da qual os danos foram sofridos" (Clérambautt apud GarCia, 1995:169-170). Entre a afirmação de autoridade dos psiquiatras franceses de 1929 e os de 1971, o salto é, para García, nulo: o único instrumento proposto para reduzir ou aniquilar a força daqueles que discutem o campo da prática é o recurso à repressão, essa mesma repressão que negam representar com sua ciência. 
são do desenvolvimento do homem, sendo os anormais, por essa razão, denominados 'deficientes mentais'.

Os anormais, os deficientes mentais e o 'franco alienado'41 tornam-se objeto do mesmo discurso científico e são todos incluídos, por Juliano Moreira, na categoria de 'estados psicopáticos'.

Terá notado, talvez, o leitor, que sob a rubrica de estados psicopáticos passei eu em revista nāo só os estudos mórbidos originários, mas ainda as 'personalidades psicopáticas' do Prof. Kraepelin. E o que é mais: ainda alguns outros estados mórbidos em grupos à parte. (Moreira, 1912b:315)

O saber psiquiátrico será, portanto, o saber sobre a psicopatologia do indivíduo, seja ela doença mental propriamente dita, quer dizer, a loucura, a doença dos "verdadeiros alienados", seja ela deficiência mental, que caracteriza os "anômalos morais", "delinqüentes recidivistas ainda quando se demonstre a sua absoluta normalidade intelectual concomitante", toxicômanos, mesmo inteligentes, que não se libertam dos tóxicos e por insuficiência de instrução pararam num estado primitivo intelectual, os epiléticos, que são "doentes que vão de degradação em degradação", os sifilíticos, os "instáveis", os "querelantes" (Moreira, 1905:167).

Introduz-se, dessa forma, a concepção de anormalidade como psicopatia, que justifica em termos médicos diversas medidas de ordem prática, representativas da formação do novo sistema de assistência psiquiátrica brasileiro,

\footnotetext{
${ }^{41}$ Sobre o emprego dos termos relativos à deficiência mental, conferir MOREIRA (1912b; 1920b). Em 'Falsos testemunhos por desvios mentais' (1912b), aparecem as seguintes classes: maníacodepressivos, paranóicos, dementes-paranóides, alcóolicos e outros intoxicados (degenerados nos quais o alcoolismo apenas cria o aparecimento de delírios complexos), psicopatas constitucionais (degenerados e desequilibrados com perturbaçóes pitiáticas), débeis mentais, epilépticos (degenerados em que as reações convulsivas são apenas um modo de descarga nervosa, podendo alternar com outros modos de exteriorização doentia). Em 'A questão da incapacidade civil' (MOREIRA, 1920b), a noção de 'loucos de todo gênero' tem um significado técnico muito restrito, pois há o louco como doente de um processo mental ativo, os enfermos ou anômalos (idiotas, imbecis, cretinos, débeis mentais), os regredidos ou degradados por involução cerebral (dementes precoces ou senis), que nem sempre são considerados casos de loucura propriamente, mas incapazes e alienados. Juliano Moreira “justifica as designaçōes propostas mostrando que ao par dos loucos de todo o gênero há também os 'deficientes mentais' que merecem a proteção da lei" (Moreira, 1920b:163). Dr. Carrilho levanta a questáo do conceito de "anômalos morais", perguntando a Juliano Moreira se "ficam compreendidos nas expressões apresentadas para substituir 'loucos de todo o gênero', convindo lembrar que já Ingenieros, na sua classificação psicopatológica dos delinqüentes, dera um lugar distinto a estes anormais, que desta maneira precisam também ser estudados no ponto de vista de sua capacidade civil" (CARRILHO apud MOREIRA, 1920b:108).
} 
vigente a partir de 1900. Essa concepção estabelece uma descontinuidade na psiquiatria brasileira, tanto em sua teoria quanto em sua prática, evidenciada pelo surgimento da categoria das 'personalidades psicopáticas', que explicita a noção médica de 'anormais', na qual se incluem todos os degenerados (sifilíticos, epiléticos e alcoólatras), além dos estados mórbidos classificados por Kraepelin como congênitos - nervosidade e psicopatia dos irritáveis, instáveis, instintivos, disputadores, mentirosos e fraudadores, antisociais, tocados, exaltados, fanáticos (Moreira, 1921:188).

Uma nova classificação das doenças mentais torna-se, então, uma exigência por parte dos próprios psiquiatras, visto que as nosologias do século XIX, utilizadas pela psiquiatria brasileira - principalmente a nosologia moral de Esquirol e a nosologia organicista de Charcot - não dão conta da novidade do saber psiquiátrico que aparecia, na medida em que consideram a doença mental somente do ponto de vista da loucura, cujo conceito é, ele mesmo, reformulado no século XX e ligado à concepção da anormalidade.

O saber psiquiátrico torna-se, nesse sentido, mais amplo e necessita de uma definiçăo clara e distinta dos diferentes tipos de alienação, além de uma diferenciação conceitual entre a anormalidade e a verdadeira doença mental, diferenciação que permanece obscura nos textos dos psiquiatras da época. É somente quando a difusão do saber psiquiátrico atinge o campo da medicina legal, ou seja, é somente na prática psiquiátrica de diagnóstico legal da doença mental que essa distinção é de certa forma explicitada, pois exige-se da psiquiatria seu laudo na determinação do estado de morbidade mental do indivíduo, a partir do qual poderá ser julgado culpado ou inocente, ouvido como testemunha nos julgamentos, ou, ainda, considerado incapaz ou capaz para a vida civil.

A partir de considerações sobre a medicina legal é que os psiquiatras tentaráo definir com maior clareza essas anormalidades mentais, ao delimitar melhor o campo da anormalidade, embora de forma ainda bastante obscura. Tais anormalidades serão analisadas como pertencentes sobretudo à esfera moral, independentes das anomalias intelectuais e dos "verdadeiros loucos", reconhecidos como "doentes mentais propriamente ditos", os quais serão classificados como "anômalos morais perigosos, criminosos constitucionais" (Camillo, 1920:127). Eles serão diferenciados do homem normal por determinadas características de comportamento - incapacidade de bem julgar, de se conduzirem do ponto de vista moral, ingestão de tóxicos etc. Os anormais apresentam-se perigosos, mesmo que de modo latente. 
Individuos assim mentalmente caracterizados que näo apresentam idéias delirantes säo ao contrdrio lúcidos e raciocinantes, porém incapazes de se conduzirem no ponto de vista moral, privados das noçōes de ética e da faculdade de bem julgar, turbulentos, toxifilos e reincidentes na prática de delitos e de reạ̧oes antisociais de variados aspectos. (Camillo, 1920:127)

A principal característica do anormal será sempre a periculosidade, mesmo que de forma latente. Com base na noção de periculosidade latente, surgem planos de prevençáo contra a doença mental e a criminalidade por meio da assistência psiquiátrica aos epiléticos e alcoólatras, da propaganda contra bebidas alcóolicas e a favor da seleção dos imigrantes e dos soldados (com exame do estado mental), que são medidas práticas próprias da psiquiatria do início do século $\mathrm{XX}$, fundamentadas cientificamente pelo novo modelo teórico, a partir do conhecimento das causas da anormalidade e da doença mental. 


\section{2 \\ Um Novo Modelo Teórico}

\section{A Questāo da Classificaçāo}

O modo de pensamento desenvolvido por Juliano Moreira será uma das condiçóes de possibilidade do surgimento, no Brasil, de uma linha psiquiátrica finalmente bem definida, que suscita o debate científico entre nossos alienistas, colocando em xeque toda a fundamentação teórica até então sustentada.

Sua teoria se baseia no modelo de Kraepelin, grande reformador da psiquiatria clássica. $O$ trabalho teórico de Juliano Moreira denota o ideal científico do final do século XIX, que se estende até nosso século, de fazer o discurso da medicina clínica penetrar no conhecimento sobre a loucura. Seu objetivo é obter uma objetividade do mesmo tipo que a médica, por meio de seus estudos no campo da etiologia orgânica dos distúrbios mentais de maneira muito mais articulada. A teoria da degenerescência desenvolvida por Morel lhe fornece uma base para que o estatuto de cientificidade pareça, nesse sentido, ser alcançado.

A abordagem puramente organicista, a que a psiquiatria tende a ser levada por meio do argumento da degenerescência fisiológica, é logo vista como insuficiente para a compreensão da racionalidade da loucura, do mesmo modo como foram as definiçōes morais. Há uma exigência de que se estabeleça uma integração, interna aos mecanismos das moléstias mentais, entre os elementos físico e psicológico, para que a lesão psicológica corresponda à lesão física. A conjunção desses dois aspectos pretende agora eliminar a antiga ambigüidade entre natureza orgânica e natureza moral da loucura, reunindo todos os elementos considerados efetivamente pertinen- 
tes à sua inteligibilidade. Essa exigência está explícita em todos os estudos sobre a etiologia e meios terapêuticos. Ela se manifesta num corpo teórico, distinto da teoria moral, na medida em que faz questão de afirmar quão imprescindível é a complementação recíproca de conceitos da anatomia patológica, da clínica médica e da psicologia experimental, insuficientes se tomados isoladamente.

Na introduçäo à parte clinica do trabalho, Kraepelin mostra a insuficiência destas bases tomadas isoladamente e conclui que somente o quadro conjunto dos casos clinicos tomados em sua evoluçāo do comeşo ao fim da moléstia pode fornecer elementos necessários a seu agrupamento com os fatos and́logos. (Moreira \& Peixoto, 1905:204)

Constitui-se, assim, uma teoria que pretende ser psicológica, diferente da teoria de base moral, a qual, ao relacionar as lesóes físicas às lesōes psicológicas, considera a evolução da doença sob esses dois aspectos. Para tanto, a história do indivíduo - os antecedentes da moléstia no indivíduo e na família - ganha importância e acentua a especificidade da lesão psicológica em relação à especificidade de sua etiologia. Estabelece-se, assim, uma descontinuidade entre o saber prioritariamente psicológico da psiquiatria do século XX e o saber moral do século XIX, em que a especificidade dos diversos tipos de doença mental era remetida à generalidade causal.

O método de Kraepelin constitui-se num contexto teórico em que a ciência médica se fazia por meio da descriçăo e da classificação. Descrição minuciosa dos sintomas e da evolução de diversos tipos de doença e constituição de agrupamentos que garantissem um julgamento diagnóstico e prognóstico.

Juliano Moreira tenta trazer os psiquiatras brasileiros para essa racionalidade médica representada pela teoria de Kraepelin, mostrando sua função de ciência de observação e, como tal, a recorrência à classificação como um balanço das aquisiçōes obtidas. Em sua opinião, quanto mais estabilizada a ciência, mais numerosas as classificaçôes, pois expressam as tentativas dos investigadores ao trilharem os mais diversos caminhos do conhecimento:

Em todas as ciências de observação, de quando em quando é preciso dar um balaņ̧o das aquisiçōes feitas no caminho percorrido. Entäo tende o espirito humano a coordenar em grupos os fatos observados. (...) Incontestavel porém é que o circulo máximo das divergências entre os estudiosos de cada ciência se vai estreitando cada vez mais para maior proveito nosso. (Moreira, 1919:93)

Embora a elaboração de um quadro classificatório possa parecer uma tarefa secundária na obra de Juliano Moreira, ela é efetivamente uma questão 
de relevo na teorização da psiquiatria do início do século XX. E sua importância será dada pela sua relação com uma necessidade extracientífica, de psiquiatrização do Estado, conforme veremos mais adiante.

Em 1908, logo após a fundação da Sociedade Brasileira de Neurologia, Psiquiatria e Medicina Legal, propõe-se a elaboração de um projeto de classificação de doenças mentais que apresente um plano de trabalho "até certo ponto uniforme", para conciliar duas posiçōes - a que rejeita as classificaçōes, e a de Pinel, que afirma que é preciso determinar no quadro nosológico o lugar de uma doença dada. Dessa posição conciliatória resulta a noção de método classificatório como um procedimento que não deve ser o mesmo das ciências naturais, aquele que coordena objetos, subordina-os uns aos outros e compara os grupos assim constituídos, estabelecendo famílias, gêneros, espécies e variedades. Pois, de acordo com Kraepelin, lembra Juliano Moreira, "a doença encarada como entidade é uma abstração do espírito humano" (Moreira, 1919:93).

A exigência de uma classificação mais uniforme é manifestada claramente em 1910, devido à necessidade da Repartição Geral de Estatística (do governo do estado) de adotar em seus inquéritos, em meio a uma multiplicidade de classificaçooses, uma classificação de doenças mentais que reunisse o maior número de adeptos. Daí, certamente, surge a noção de uma classificação como possibilidade de democratização do saber humano, como a considera Juliano Moreira (Moreira, 1919). ${ }^{42}$

42 Ao buscar uma classificação uniforme, Juliano Moreira dedica-se a um estudo histórico. Para ele, até o século XVIII, nenhuma era digna de menção. Refere-se à de Boissier de Sauvages (1767) como a primeira classificação baseada na dos naturalistas. Ele ressalta as seguintes classificaçōes: no final do século XVIII, a de Arnold, alienista inglês, sob a influência de Locke e Hartley, é precursor de uma razoável discriminação das loucuras - loucura nas idéias e nas noçōes - delusória, fantástica, imaginativa, impulsiva etc. Na França, Pinel, impelido pelas grandes idéias humanitárias de seu tempo, começou em pleno período tempestuoso da Revolução a tirar algemas e cadeias dos alienados. "De então em diante é que se começou a falar em classificações feitas sob critério psicológico, sintomatológico ou etiológico" (MOREIRA, 1919:93). Esquirol, que, em 1816, faz uma classificação influenciada por Rush. Em 1857, Morel, quem melhor classificou a partir de critérios etiológicos. Apareceu pela primeira vez o conceito de degeneração hereditária; deve ser considerado, segundo Juliano Moreira, o precursor de quase todas as sínteses clínicas que surgiram posteriormente em psiquiatria. Em 1900, Toulouse condena as divisóes etiológicas; em sua opinião, a loucura é um perturbaçāo das faculdades intelectuais, que tende a impedir o indivíduo de viver em sociedade; ele aceita os sintomas físicos como os caracteres de classificação mais relevantes para as doenças mentais. Em 1910, Serieux concilia as idéias de Magnan, de Kraft-Ebing e as de Kraepelin. Em 1914, Régis, que concentra o maior número de adeptos é contrário às idéias de Kraepelin. Juliano 
Logo depois da fundaf̧ão da Sociedade Brasileira de Neurologia, Psiquiatria e Medicina Legal, na sessão de 5 de abril de 1908, por proposta do Prof. Austregésilo foi designada uma comissäo para apresentar um projeto de classificaf̧ão de doenças mentais, o qual pudesse servir de base ds estatisticas dos manicômios nacionais. Eleitos membros dessa comissão foram os Drs. Eiras, Afrânio Peixoto, Roxo e eu. Bem ponderados os prós e os contras do problema foram adiando-lhe a soluçäo os comissiondrios da sociedade. Em 1910, porém, a Repartiçäo Geral de Estatistica desejando adotar em seus inquéritos uma classificação de doenças mentais que reunisse um maior número de adeptos, pediu conselho ao presidente e vice-presidente da nossa sociedade. Este último, Dr. Eiras, lembrou que ainda näo nos haviamos desobrigado da incumbência de que nos investiram os confrades na referida sessāo. Por insistência do colega Austregésilo e ausência do resto de vossa comissão relato eu hoje o vosso quesito e vos digo porque alugamos ao agrupamento que será apresentado a vossa aprovaçāo. (Moreira, 1919:93)

Com essas palavras, Juliano Moreira apresenta um projeto de nosografia a ser instituída nos manicômios de todo o Brasil com o objetivo de fundamentar suas estatísticas. À primeira vista, a questão da classificaçáo em psiquiatria parece minimizada entre nossos psiquiatras, devido às sucessivas prorrogaçóes para sua elaboração. A aparente despreocupação com que o assunto é tratado não se deve contudo a uma real independência da formulaçāo de um novo corpo teórico em relação à classificação, mas ao fato de já se ter na prática adotado a classificação de Kraepelin, introduzida entre nós pelo próprio Juliano Moreira.

$\mathrm{Na}$ realidade, a teoria psiquiátrica não pode ser pensada, em termos conceituais, como desvinculada da nosografia, como se a nosografia significasse apenas um instrumento de conhecimento, como é, por exemplo, o caso da utilização da punção lombar no diagnóstico. Ao contrário, a teoria se constitui a partir de uma formulação de conjunto na qual o método da classificação é constitutivo da própria formulação do discurso psiquiátrico.

Juliano Moreira, contudo, tenta afastar-se de um pensamento estritamente classificador, rejeitando-o como uma abstração do espírito: "As doenças não são seres de caracteres fixos, definidos e permanentes. A doença como desvio da normalidade que é, é uma exceção biológica. Demais, a doença encarada como entidade é uma abstração do espírito humano" (Moreira, 1919:94).

Moreira traça, assim, uma história das idéias e de seus precursores, transcrevendo, além das acima citadas, as classificaçōes da Sociedade Médico-Psicológica de Paris, a de Briand, de Vigoureux e Trelle (1914), de Schelle (1885) de Hans Roemer (1912) e a da Sociedade Alemã de Psiquiatria (1912) (MOREIRA, 1919:93). 
Porém, na elaboração de sua teoria não consegue dela se libertar. Em todos os seus trabalhos há uma linha de pensamento bem clara que toma a doença sempre dentro do enfoque classificatório. A delimitação de classes nosológicas está sempre presente. A necessidade explícita de decidir se os traços apresentados pela doença podem ser considerados uma classe propriamente, ou se são apenas sintomas que caracterizam diversas classes, é uma necessidade que se impõe na definição mesma dos conceitos patológicos:

$O$ dilema existe: ou a paranóia é a doença mental que descrevemos e paranóides são as sindromes que ocorrem em tantas outras doenças mentais, ou esse termo serve a estes estados e então, força é buscar um outro que designe aquela doença. O que se impōe é que não são a mesma coisa eportanto näo devem ter o mesmo apelido. (Moreira \& Peixoto, 1914:27)

A mudança que ocorre quanto ao problema da classificação não é, como queria fazer parecer Juliano Moreira, a negaçāo de sua função fundamental na formulação do corpo teórico, pois a nova teoria ainda se faz essencialmente por meio do estudo dos grupos nosológicos, da classificação das causas e sintomas da doença mental.

Entretanto, seu valor não é mais considerado absoluto, como acontecia com Pinel. Tenta-se, a exemplo de Kraepelin, a conciliação de duas posiçóes opostas - "a que subordina a teoria à classificação e a que abomina" (Moreira, 1919:94).

Dessa maneira, a psiquiatria começa a pensar uma nova forma de abordagem da doença mental, que pretende fazer com que a teoria não apenas se reduza a um quadro de essências abstratas, que encerra a doença numa classe ideal, mas que se componha de aspectos que permitam maior mobilidade na compreensão dos distúrbios psíquicos, respeitando o seu desenvolvimento, sua evolução próprios, sua própria história. Para chegar a essa composição, Juliano Moreira estuda todas as modalidades de classificação, os diversos métodos possíveis, tornando-os complementares entre si, todos apresentando pontos igualmente válidos. Para ilustrar sua idéia, ele usa a imagem da democratização do saber: "É assim que se democratiza o saber humano. A psiquiatria está de fato nesta fase revolucionária" (Moreira, 1919:94).

A idéia de democratização da ciência psiquiátrica diz respeito a uma abertura correlata do pensamento de Kraepelin, aberto a uma diversidade de elementos que a compóem, ao reunir a anatomia patológica, as causas e os sinais clínicos, observados em sua evolução do começo ao fim da moléstia, complementados pelos sintomas trazidos dos estudos em psicologia experimental. Ela se diz resultante de um balanço das aquisiçóes feitas no 
campo da psiquiatria, exigido pela tendência a coordenar em grupos os fatos observados. Essa tendência é justamente determinante, no âmbito do conhecimento, do papel da psiquiatria como ciência classificatória.

O Tratado de Psiquiatria (1856-1926), no qual Kraepelin desenvolve a teoria sobre a doença mental, enfatizando a clínica médica para sua elaboração, é uma grande classificação não só dos grupos de doenças mentais, mas também de todos os componentes que permitem a sua compreensão.

A abordagem mesma de Kraepelin é nosológica e etiológica. Nessa época, os principais temas da psiquiatria estão colocados no quadro das causas, que dá um nexo teórico às questóes sexuais, raciais, do problema da civilização, da hereditariedade e da educaçáo na formaçáo da personalidade dos indivíduos dentro do panorama da causalidade.

O sumário apresentado no primeiro volume do Tratado de Psiquiatria de Kraepelin, obra que condensa toda sua teoria, deixa claro que o plano de trabalho está perfeitamente de acordo com a idéia de classificação como fundamento teórico, como uma nosologia - a das causas de alienação. Os principais temas pesquisados pela psiquiatria da época estão ordenados dentro de um quadro classificatório de causas, que conferem um nexo teórico aos problemas sexuais, raciais, o problema da civilização, da hereditariedade e da educação na formação da personalidade dos indivíduos, numa perspectiva etiológica. ${ }^{43}$

A questão da classificação é tão fundamental no modelo de Kraepelin, assim como em todos os outros modelos psiquiátricos, que já "na introdução à parte clínica de seu trabalho, ele analisa as bases sobre as quais têm sido estabelecidas as classificaçōes" (Moreira \& Peixoto, 1905:204). Como explica Juliano Moreira, Kraepelin "mostra a insuficiência dessas bases tomadas isoladamente, e conclui que somente o quadro do conjunto dos casos clínicos tomados em sua evolução do começo ao fim da moléstia pode fornecer elementos necessários a seu agrupamento com os fatos análogos" (Moreira \& Peixoto, 1905:204). Enfim, é todo um sistema de conhecimento classificatório que caracterizará o modelo alemão adotado por Juliano Moreira.

${ }^{43}$ No Sumário do Tratado de Psiquiatria, de Kraepelin, lê-se: "Introdução. I - causas da doença mental: A. causas externas 1. Causas somáticas 2. Causas psíquicas B. causas internas 1. Predisposição geral: idade - sexo - raça e clima - condições gerais de vida - cidade e campo - profissão 2. Predisposição pessoal: hereditariedade - degenerescência - tipos hereditários - sinais degenerativos - (...) educação." (KRAEPELIN, 1856-1926:introdução). 
Esse modelo apresenta um plano de trabalho cujo método se esforça em ser médico, mas diferente do das ciências naturais, até então utilizado na formaçáo do discurso teórico da medicina mental. Contudo, seu método médico é apenas uma outra modalidade, que consiste em observar o curso natural das perturbações mórbidas, tomar minuciosamente seus sintomas, de acordo com a ordem de apariçăo; observar o seu desenvolvimento espontâneo e sua terminação natural, para poder distinguir o essencial do acessório. E, portanto, o mesmo procedimento comparativo das ciências naturais aplicado à psiquiatria.

A razão dessa tentativa de abandono do modelo das ciências naturais reside no fato de que, conforme seu método, a racionalidade da loucura é puramente sintomática. Consiste em agrupar as manifestações aparentes, os sintomas, seguindo sua ordem natural, uma atitude puramente fenomenológica, que se limita a constituir um quadro nosológico. Esse sistema vinha sendo, desde o século XIX, criticado. Inicialmente, por não se referir a nenhuma etiologia, e, mais tarde, por este mesmo motivo e pelo reconhecimento da inadequação de seu enfoque à questão psicológica. ${ }^{44}$

A dificuldade de definir o critério que se impōe à formulação da nosografia é, portanto, flagrante. Os critérios sintomático, etiológico ou psicológico, são sempre discutidos pela psiquiatria. Juliano Moreira mostra que é depois de Pinel que se começam a definir critérios nosológicos, a se falar em classificaçóes feitas sob critério psicológico, sintomático e etiológico. Em sua opinião, "quem melhor classificou a partir de critérios etiológicos foi Morel em 1857 (...), [que] deve ser considerado o precursor de todas as sínteses clínicas que surgiram depois em psiquiatria" (Moreira, 1919:95).

No Brasil, a linha de Pinel, aqui conhecida por meio dos textos de Esquirol, suporte teórico sobre o qual se institucionalizou o hospício, havia sido substituída no final do século XIX, como afirma Afrânio Peixoto, pela classificação de Charcot. A obra de Charcot é um exemplo do método

${ }^{44} \mathrm{Em}$ L'Hystérie, Trillat (1971) salienta a afirmação de Freud: "o insucesso da histeria deve-se à aproximação exclusivamente nosográfica que a escola da Salpetrière tomou, colocação que não convinha a um assunto exclusivamente psicológico" (FrEUd apud TriLLAT, 1971:130). Segundo Foucault, é com a crítica de Freud que a concepção de doença mental, tal como a compreendemos agora, torna-se possível. Freud contorna a classificação dirigindo-se à investigação da relação médico-paciente. A essa questão, Foucault remete a discussão do papel desempenhado pelos médicos, com seu conhecimento médico sobre o homem, no desenvolvimento das estratégias de internamento e dominação em nossa sociedade. 
anatomoclínico, de critério evidentemente etiológico, cujo método repousa essencialmente na pesquisa da diferença; procedendo por comparação de sintomas, justapõe casos mais e mais semelhantes para ver até que ponto vai a diferença, até chegar à identidade, quando a série de provas não deixa mais nenhuma diferença, formando finalmente uma classe nosológica.

Os sintomas, desse modo agrupados, vão ser remetidos às lesóes orgânicas que constituem a chave de seu sistema. Pelo procedimento da anatomia patológica, que fornece o conhecimento das lesóes, juntam-se os elementos esparsos anteriormente isolados pela observação das diferenças. A primeira etapa desse método deriva-se das ciências naturais - observação das diferenças dos sintomas, sempre procedendo por comparação. Mas a etapa complementar só se realiza com o exame anatomopatológico depois da morte, espécie de recapitulação constitutiva da doença, único momento em que se pode considerar com segurança um conjunto de sintomas como atributos da lesão. O efeito sintético e constitutivo da peça anatômica só é possível se anteriormente o método das diferenças permitir o isolamento de cada elemento dado num conjunto e distinto de um elemento contínuo dado num outro conjunto.

No modelo alemão, a referência à etiologia da doença mental como constituinte da cientificidade da psiquiatria e, sobretudo, a busca de causas objetivas, por meio do exame da patologia clínica, assinalam as bases sobre as quais se devem estabelecer as classificaçóes em psiquiatria.

Em meio à multiplicidade de nosografias, Juliano Moreira vê vantagem em adotar um plano de trabalho que aproveita elementos das diversas escolas - a classificaçāo de critérios etiológicos não deverá mais rejeitar os fundamentos provenientes dos métodos da psicologia experimental, ${ }^{45}$ como fizeram os organicistas, sem se basear exclusivamente no método das ciências naturais.

A anatomia patológica deverá auxiliar o psiquiatra, mas não deve ser tomada de forma tão decisiva quanto para Charcot. ${ }^{46}$ Kraepelin pondera as

${ }^{45}$ A psicologia experimental, entendida por Kraepelin como psicologia científica, tem diversos ramos que estudam o aspecto normal dos indivíduos, dos povos e das raças - 'psicologia do povo', 'psicologia criminal', 'psicologia das idades', 'das raças'; "da decomposição da vida psíquica normal, encontraremos os elementos para poder julgar e explicar os diversos distúrbios mórbidos" (KRAEPELIN, 1856-1926:introdução).

${ }^{46}$ Em L'Hystérie, Trillat (1971) explica como Charcot situa a sede da histeria no encéfalo, atribuindo-a a perturbações de estruturas nervosas, comparando seu trabalho com o de 
desvantagens do método comparativo das ciências da natureza, empíricas, trazido para a medicina mental, do mesmo modo como faz a medicina geral. Sem rejeitá-lo inteiramente, atribui à anatomia patológica, que confere um caráter experimental ao saber e um caráter concreto e corporal à doença, um papel restrito na constituição da doença, assim se referindo à autópsia: "Se em outros campos da medicina estamos habituados a olhar o exame do cadáver como última confirmação de nosso diagnóstico, em psiquiatria devemos dar apenas um valor muito limitado ao exame do cadáver" (Kraepelin, 1856-1926:introdução).

Isso porque as doenças não podem mais ser tomadas como classes ideais, pois, para Kraepelin, não se trata de seres de caracteres fixos, definidos e permanentes. $\mathrm{Na}$ introdução à parte clínica do tratado, Kraepelin analisa, como ressalta Juliano Moreira, as bases sobre as quais têm sido estabelecidas suas classificações - anatomia patológica, causas e sinais clínicos -, mostrando a insuficiência dessas bases estudadas isoladamente. ${ }^{47}$

São essas as novas bases sobre as quais se devem estabelecer as classificações, uma vez superados os modelos de Esquirol e de Charcot. A anatomia patológica, cujo papel é relativo, conforme vimos, e as causas e sinais clínicos tomados no quadro do conjunto dos casos clínicos observados em sua evoluçāo do começo ao fim da moléstia, acrescidos de dados da psicologia experimental, fornecerão agora os elementos necessários ao agrupamento de cada doença com os fatos análogos.

A conexão que antes parecia estranha torna-se justamente o ponto de validação do novo discurso psiquiátrico, resultando numa tentativa de mudança do critério de cientificidade; é pela reunião de conceitos de origem diversificada que Kraepelin realiza uma síntese nessa nova etapa da psiquiatria. O elemento psicológico conforme é analisado pela psicologia experi-

Briquet. Briquet e Charcot concordam em que há a participação orgânica. Porém, os dois compreendem a articulação com a clínica de maneiras diferentes. Enquanto, para Charcot, a histeria deve-se a um lesão dinâmica, sendo que o sintoma é ramificado diretamente sobre a lesão, para Briquet o sintoma é produzido pelo sofrimento da porção do encéfalo destinada a receber as impressōes e sensaçōes.

${ }^{47}$ Em Classificaşöes em Medicina Mental (1919), Juliano Moreira discute, ainda, a necessidade de uma pesquisa multiderecionada, para poder trabalhar com uma etiologia das afeç̧ōes do cérebro a partir das formulaçōes de classes, isolando suas causas; para melhor compreender o quadro nosográfico e perceber com mais clareza a sua racionalidade, é preciso esmerilhar o desenvolvimento patológico em todas as direçōes. 
mental, até então negado pelos cientistas para a formação do quadro nosológico, torna-se muito importante na definição das doenças do cérebro. "Emil Kraepelin, de Munique, discípulo notável de B. Gudden e do psicólogo Wundt, aliou os ensinamentos fornecidos pela observação clínica" (Moreira \& Peixoto, 19095a:204), pois não se pode ignorar a influência dos fatores psicológicos sobre os físicos. $\mathrm{A}$ análise psicogenética deve ter $\mathrm{o}$ mesmo peso que a organicista para se elaborar uma teoria dos distúrbios psíquicos, aqui introduzida por Juliano Moreira.

Essa formulação impõe novas dificuldades à ciência psiquiátrica; ela requer um profundo conhecimento de cada um desses aspectos separadamente e da sua relação com toda a economia fisiológica. Cita-se Tuke pela sua argumentação científica capaz de abranger, numa concepção mais geral de doença mental, os componentes mental e físico. Em Clinoterapia, Difusão e Resultados no Tratamento das Psicoses, afirma-se "que a afecção mental está ligada a uma hiperemia contínua, cujos efeitos repercutem em cada órgāo da economia, a qual por sua vez afeta, indiretamente embora, a vitalidade da célula. Há portanto não só perturbações mentais, mas ainda desordens físicas" (Moreira, 1901:110).

A desordem que caracteriza a alienação não pode mais ficar limitada ao campo moral, tampouco à etiologia das lesóes orgânicas. Trata-se, de acordo com Juliano Moreira, de desordens de toda natureza: desordens dos nervos, do cérebro - "o doente necessita de toda energia nervosa para deter os progressos de decadência e da desorganização do cérebro" (Tuke apud Moreira, 1901:110) - e desordens intelectuais e afetivas - "enfraquecimento psíquico (inteligência e sentimentos afetivos)" (Moreira \& Peixoto, 1905:204) interagindo na determinação dos estados mentais patológicos. As desordens do sistema nervoso e do cérebro marcarão o aspecto médico da psiquiatria, sendo estudadas como doenças orgânicas, com base em dados da medicina clínica. As perturbaçóes da inteligência e da afetividade remeterão a antigos conceitos formulados desde o século XVIII.

Isso pode ser dito na medida em que há, na nosografia do modelo alemão, evidente tendência a agrupar, de acordo com a presença ou ausência de compreensão, as perturbaçôes maiores ou menores da memória e a falta parcial ou total de conseqüência. A loucura será analisada, então, com base em todos esses conceitos que, juntos, a definirão como doença mental, da mesma maneira como ocorreu no século XIX, enfocando-a também em 
termos de desordem do comportamento, manifestada pelas perturbaçōes afetivas ligadas às paixōes e aos hábitos, conferindo-lhe portanto uma significação moral - a lesão da vontade. ${ }^{48}$

Portanto, a consciência moral e as perturbaçóes do organismo são, ambas, o lugar da doença mental. A psiquiatria se impōe agora como se estivesse definitivamente inserida no ramo da medicina clínica e anatomopatológica, sem contudo se dissociar dos efeitos psicológicos, das perturbaçóes da afetividade, explorados na nosografia de Esquirol. A classificação de Kraepelin estabeleceu entidades nosográficas onde se misturam conceitos de ordem moral com os relativos às afecçôes orgânicas, que se explicitam e se entrelaçam na etiologia e sintomatologia da doença. Vejamos, por exemplo, a 'psicose por esgotamento' (das Ershöpfangsirresein):

Sintomas - A psicose começa por insônia e agitạ̧ão. O doente inquieto, esquecido, preocupado com a morte não consegue mais reunir idéas e queixa-se de embotamento e depressão do espirito... Idéias de perseguiçăo, de culpabilidade e algumas vezes de grandeza... Hd perturbação profunda do pensamento. Desordem nos processos psiquicos. Consciência perturbada como no sonbo. Fuga de idéias. Humor móvel. Agitação motora. Alimentação dificil, recusa de alimentos. Os reflexos são freqüentemente exagerados, o pulso lento, a temperatura abaixo do normal. Muitas vezes há tendência à imundície (...). EtiologiaPneumonia, erisipela, estado puerperal hemorragias, vigilias prolongadas. (Moreira \& Peixoto, 1905:211)

Tomemos uma categoria nosográfica qualquer da classificação de Kraepelin, apresentada por Juliano Moreira, e poderemos ver de que maneira os conceitos psiquiátricos são utilizados. Eles representam os três níveis pelos quais a doença mental atinge o indivíduo, subjetivados pela perturbação do aspecto afetivo, do intelectual e do físico, entendendo-se subjetivados como relativos ao sujeito, isto é, sem levar em conta o nível social. Nessa categoria são agrupadas as perturbaçōes psíquicas que têm por causa o gasto excessivo ou a restauração insuficiente dos elementos nervosos que constituem a córtice cerebral. Sofrem influência das perturbaçōes graves do organismo, como doenças agudas, hemorragias, puerpério, 'erghatenia

\footnotetext{
${ }^{48}$ Para Birman, a questão da vontade é vista nos termos do problema da sociabilidade, no sentido que a loucura se torna alienação ao ser compreendida como a não-realização da sociabilidade no plano real ou simbólico. Entre as faculdades afetivas e a vontade se constituiria o sujeito de razão; o alienado mental se caracterizaria pelo predomínio das paixōes e por uma lesāo da vontade. As paixōes seriam afetos extremamente intensos, que ultrapassam o controle da vontade sobre elas. A sociabilidade dispõe a vontade como a dimensão primeira do sujeito moral e empírico, já que é a vontade que regula as paixões, interditando aquelas que poderiam levar à desordem a ligação entre as subjetividades (BIRMAN, 1978:89-96).
} 
intelectual ou moral', perturbação profunda da inteligência, coordenaçāo das idéias e da faculdade de pensar. A esse quadro clínico, Kraepelin acrescenta as perturbaçōes sensoriais, a fuga de idéias e a excitaçāo motora.

Se tomarmos uma categoria nosográfica qualquer da classificação de Kraepelin, apresentada por Juliano Moreira, poderemos ver de que maneira os conceitos psiquiátricos são utilizados. Eles representam os três níveis pelos quais a doença mental atinge o indivíduo, subjetivados pela perturbação dos aspectos afetivo, intelectual e físico, entendendo-se subjetivados como relativos ao sujeito, isto é, sem levar em conta o nível social.

Em toda a nosografia, as doenças são agrupadas segundo as mesmas desordens:

- no nível intelectual - 'falta de compreensão, de memória, de consciência', 'alucinações', 'delírios de imaginação', 'inteligência enfraquecida' etc.;

- no nível afetivo ou moral - 'mentirosos', 'fraudadores', 'querelantes', 'indiferentes', 'imundície', 'excitabilidade da esfera afetiva';

- no nível físico - inapetência, lesōes cerebrais, paralisia, esclerose cerebral, 'intoxicaçōes' diversas, lesão do corpo, 'tireóide' etc. ${ }^{49}$

\section{O Conceito de Doença Mental}

A partir do final do século XIX, a explicitação da concepção de doença mental torna-se, para a psiquiatria brasileira, uma exigência de formulaçăo de um corpo conceitual novo, onde o problema da alienaçáo não se restringe mais à questão da loucura propriamente dita. A noção de alienação passa a abranger uma diferenciação entre a 'verdadeira doença mental' e outras formas de distúrbios psicológicos, circunscritos no discurso psiquiátrico com o surgimento da noção medicalizada de anormalidade como uma forma de psicopatologia. Essa diferenciação torna-se premente, à proporção que o saber dos psiquiatras vai sendo requisitado para o esclarecimento de questôes de ordem jurídica, que comportam uma decisão legal a respeito do caráter de culpabilidade do comportamento do indivíduo criminoso, indisciplinado, com bases nos critérios científicos da medicina mental. Tal

\footnotetext{
${ }^{49}$ Falta de consciência, imundície, lesão são conceitos empregados a todo momento na nosografia de Kraepelin apresentada por Juliano Moreira e Afrânio Peixoto.
} 
exigência legal tem como condição de possibilidade a relação estabelecida entre a psiquiatria e a medicina e entre a medicina e o Estado.

Juliano Moreira introduz na psiquiatria brasileira uma nova concepção de doença mental, a partir da teoria de Kraepelin, onde a relação entre a loucura, a inteligência e a vontade continua sendo importante para a descrição dos mecanismos das moléstias mentais, como foi para Esquirol. Contudo, estabelece entre esses três elementos uma articulação com as lesões físicas; enquanto a loucura, na teoria da Esquirol, é sempre enquadrada apenas nas categorias das desordens da inteligência e da perversão da vontade, a psicose descrita por Kraepelin tem por ponto de partida o delírio, isto é, uma desordem intelectual e sensorial. O conceito de monomania de Esquirol, onde a loucura já não se define como desordem da inteligência mas como desordem da sensibilidade e da vontade, caracteriza a doença mental como doença moral, considerando o nível das paixōes como mais fundamental que o da inteligência, até então determinante do referencial básico para se aferir a existência ou grau da loucura. De acordo com essa concepção, a monomania pode ser de três tipos: a intelectual, lesão parcial da inteligência; a 'raciocinante' ou afetiva, cuja desordem está no comportamento (diz respeito aos hábitos, ao caráter, às açōes, às paixōes); e a monomania instintiva, lesão da vontade - o louco age por instinto, sem motivo -, que é o outro da consciência (Esquirol, 1938).

Até Esquirol, existiam diferentes formas de loucura, umas caracterizadas pelo delírio, como a lipomania, a monomania e a mania, e outras pela desrazão, como a demência e a idiotia, todas definindo a loucura pelo delírio, embora desde Pinel a psiquiatria postulasse a existência de uma loucura sem delírio. ${ }^{50}$ Juliano Moreira atribui sua causa à ação das toxinas sobre o córtice cerebral, associada a perturbaçōes gerais do organismo; essa explicitação se dá numa linha puramente organicista. Porém, a descrição recai sobre as perturbações intelectuais e sensoriais na psicose com delírio infectuoso grave, como, por exemplo, "alucinações múltiplas, concepçōes delirantes extravagantes, estado de excitação com ansiedade, confusão, desorientação. Por vezes recusa de alimentos, tentativa de suicídio, atos de violência" (Moreira \& Peixoto, 1905:209). E nos casos mais graves, problemas de ordem moral: "perda da memória, recusa de alimentos, imundície, indiferença. Por vezes sinais de lesōes cerebrais orgânicas (hemiplegia, perturbaçōes da palavra, ataques epileptiformes)" (Moreira, 1891:209).

${ }^{50}$ Sobre a concepção de loucura em Esquirol, conferir MACHADO, 1978:386-392. 
Os psiquiatras brasileiros começaram, no século $\mathrm{XX}$, a explicar as afeç̧ōes mentais por meio da relação das reaçóes físicas com as lesões da vontade e da consciência:

Os estados depressivos näo são mais que a consciência do estado do corpo do hipotonus dos músculos lisos e estriados, o resultado da desnutrição muscular e cerebral, é de prever que a melhora do estado geral, a reparaşão das perturbaçōes nutritivas do organismo do cérebro, modifiquem o estado kinestesico que repercutia na consciência uma impressäo dolorosa a hiperestesia fisica do melancolico, com suas dores morais angustiosas, com seu estado abúlico acentuado, muito precisa de qualquer coisa que lhe suprima a atividade dos músculos da vida de relação, por isso que o paciente necessita que se lhe poupe todo ato voluntário, qualquer determinaçāo própria. (Moreira, 1901:245)

Estabelece-se um elo entre a teoria da degenerescência, no qual a loucura quase deixa de ser uma doença mental para se definir como uma anormalidade de causas biológicas, e a teoria de Esquirol, que se constitui como um estudo das desordens do comportamento social, de causas morais.

Mas, quanto à natureza da doença mental, essa correlação não elimina inteiramente a antiga duplicidade do discurso psiquiátrico, pois ela situa o conjunto conceitual moral e o conjunto de elementos fisiológicos em diferentes níveis, ou melhor, alguns conceitos entram na ordem da etiologia, sendo por isso determinantes da doença, e outros aparecem na ordem da sintomatologia das simples aparências. Dessa forma, na psicose descrita por Kraepelin, por exemplo, as lesōes orgânicas constituem a ordem da causalidade, enquanto os distúrbios afetivos se agrupam nos sintomas. É nesse sentido que continua havendo uma duplicidade no saber psiquiátrico inaugurado por Juliano Moreira, a despeito da relação de interioridade que se pretende estabelecer entre esses dois níveis.

No início do século $\mathrm{XX}$, tal diferença de níveis termina por restringir ainda mais, no que tange ao discurso teórico, o valor de verdade do componente moral, e acentuar o papel das lesões orgânicas, visto que as últimas pertencem à etiologia, que se superpôs, cronologicamente, à descrição do sintoma como critério científico de definição e classificação das moléstias mentais. Contudo, a relevância do componente moral se faz notar textualmente, quando se afirma, quanto às intoxicaçōes crônicas, que, "porém, somente se ocupa o Prof. Kraepelin das denominadas voluntárias: alcoolismo, morfinismo e cocainismo" (Moreira \& Peixoto, 1905:208). ${ }^{51}$ Do ponto de

${ }^{51} \mathrm{Na}$ classificação das intoxicaçōes crônicas apresentada por Moreira e Peixoto, vemos que Kraepelin estuda o alcoolismo como embriaguez, como crônico, o delirium tremens, a psicose 
vista da articulação dos conceitos de natureza orgânica com os de natureza moral, nessa época acredita-se ter conseguido uma síntese teórica coesa dos dois tipos de etiologia - moral e física. Juliano Moreira exalta essa síntese, que não deve ser entendida no sentido dialético de um esquema que teria Pinel como tese, Morel como antítese e Kraepelin como a síntese dos contrários que os transcende, conforme poderíamos imaginar. Tal síntese pode, no entanto, ser assim denominada, na medida em que articula os diversos níveis, por meio de uma concepçáo de doença mental que esmerilha em todas as direçóes a sua racionalidade, conectando princípios que pareceriam incompatíveis entre si aos olhos dos psiquiatras que o antecederam.

$\mathrm{Na}$ realidade, a síntese buscada por Juliano Moreira náo chegou a ser realizada. Nas formulações teóricas dos trabalhos sobre doença mental, não se conseguiu evitar uma forte tendência a enfatizar a etiologia fisiológica. O que se observa é o predomínio do valor da observação e da análise das funçōes orgânicas, principalmente as cerebrais. Recai-se sempre na tentativa de repetir os procedimentos da medicina geral, cujas afirmaçóes apoiaram-se na dissecação dos cadáveres, nas análises dos laboratórios e na observação dos doentes. As causas sociais e psicológicas terminam sendo, de certo modo, relegadas a segundo plano, pois parecem menos científicas ao novo olhar médico. Apesar de tudo, tal fundamentação médica, embora tenha sido afirmada, finalmente não foi alcançada; até hoje a psiquiatria espera fundar-se amplamente no componente biológico. Além de lesóes específicas - provenientes do campo da medicina, muito mais do que do da psiquiatria -, nada mais foi descoberto.

Tomando como modelo a sífilis, cujo desenvolvimento poderia causar lesōes neurológicas, que por sua vez constituiriam a etiologia de distúrbios mentais, os psiquiatras positivistas buscavam confirmar o caráter de cientificidade de seu saber. Tal como a lesão sifilítica, afirma Serra, as demais sintomatologias psiquiátricas deveriam apresentar uma lesão originária. Encontrá-la - questão de tempo - seria encontrar a cura (Serra, 1979:12).

Por causa da pluralidade do novo modelo - entendendo-se por pluralidade o envolvimento com os ramos da medicina, da psicologia experimental e das questōes sociais -, Juliano Moreira define a doença mental

de Korsakof, o delírio alucinatório dos bebedores, a fraqueza psíquica alucinatória dos bebedores, o delírio de ciúme dos bebedores, a pseudoparalisia geral alcoólica. 
de maneiras diferentes, de acordo com o enfoque sob o qual está sendo analisada. É assim, por exemplo, que ora ela aparece definida do ponto de vista da medicina biológica - "A doença, como desvio da normalidade que é, é uma exceção biológica" (Moreira, 1919: 93) -, ora relacionada com fatores de ordem social: "O estado mental varia muito com os precedentes de herança e educação" (Moreira \& Peixoto, 1914:27). É por essa razão que ele é considerado aquele que "introduz no Brasil a verdadeira compreensão clínica da paranóia" (Moreira \& Austregésilo, 1923:125). Conforme afirma Austregésilo, tal compreensão insere a noção de paranóia numa perspectiva ao mesmo tempo médica e filosófica, envolvendo a subjetividade. Juliano Moreira e Afrânio Peixoto a consideram uma autofilia primitiva e originária da personalidade, nāo corrigida e incrementada pela educação defeituosa, inadaptada ao meio social, fruto da civilização. Esse conceito de autofilia abrange a noçáo de egocentrismo, concebido como inadaptabilidade do indivíduo ao meio, a qual é acompanhada de uma interpretação pessoal de hostilidade e de idéias de perseguição ativa ou passiva ou, o que é mais comum, ativa e passiva (Moreira \& Peixoto, 1914).

Em 'A paranóia e os syndromas paranóides', salienta-se o abuso do conceito de paranóia, que exige um estudo que lhe confira mais precisão. De acordo com Kraepelin, a paranóia é uma doença rara - 2 a $4 \%$ da populaçáo dos hospícios, sendo mais rara ainda entre as mulheres. Segundo tal concepção, há uma tendência errada a atribuí-la à degeneração; também é errada a tendência a incriminar a herança como causa de degeneração - essa explicação de degeneração "mais parece ter sido gravada de imaginárias culpas; quanto ao atavismo, pior ainda, é uma mera fantasia" (Moreira \& Peixoto, 1914:27).

Ao paranóico atribui-se, nessa teoria, apenas a persistência do modo de ser originário - o subjetivismo -, devido a uma deficiência de educação, de treinamento e da cultura. Nesse caso, a paranóia é originária, isto é, a educaçăo teria permitido crescerem livremente os gérmens da autofilia egocêntrica, favoreceu-os, ampliou-os, de modo que os atritos com o meio social tornamse as causas ocasionais do desequilíbrio definitivo do paranóico.

Tal desequilíbrio explica por que a vida do paranóico é uma eterna luta da ação e reaçáo incessantes, que faz com que ele seja considerado "o mais incômodo e perigoso dos insanos" (Moreira \& Peixoto, 1914:27). É uma ilusão atribuir à paranóia fases bem esquematizadas de perseguiçăo e grandeza. A autofilia não tem fase, ela é perene e não resulta dos erros sensoriais 
surgidos num terreno em que a consciência se enterra na demência. Pois a autofilia é o fundamento da paranóia. ${ }^{52}$

Se no século $\mathrm{XIX}$ as teorias psiquiátricas já trabalhavam com conceitos de ordem tanto médica, fisiológica, quanto social e filosófica, no século XX o que dá forma à concepçáo de doença mental é a homogeneidade de certos conceitos. Tais conceitos são aparentemente refratários entre si, mas não representam contradiçôes, porque são analisados sempre visando a um âmbito mais geral, compatível com o saber psiquiátrico que estabelece o caráter de permeabilidade dos vários aspectos da loucura - moral, físico, psicológico - intrinsecamente ligados, cada um repercutindo no outro.

A partir do novo modelo teórico, os sintomas da alienação definida na sua relação com a moralidade são remetidos aos processos infectuosos e às intoxicaçōes alcóolicas, cocaínicas etc., que ganham lugar de destaque na etiologia degenerativa dos estados mentais.

Ao retomar antigos conceitos oriundos da teoria psiquiátrica de Esquirol (imundície, tranqüilos, agitados), Kraepelin coloca-os ao lado de lesōes orgânicas (causadas pela ação das toxinas sobre a córtice cerebral), e, ao mesmo tempo, deixa lugar para consideraçôes sobre a sociogênese dos distúrbios psíquicos, atribuindo à doença mental uma múltipla causalidade, que já aparecia na psiquiatria do século XIX. A diferença é que, na nova concep-

52 A sintomatologia da paranóia seria a seguinte: reconhecimento da hostilidade do meio que produz em certos paranóicos reaçóes depressivas, de humor irregular, de indefinido mal-estar, acompanhado de inapetência e insônias; suscetibilidade extrema que chega à suspeita completa, como defesa às supostas hostilidades do meio; os paranóicos procuram um abrigo mais seguro, por isso não podem ficar parados; perseguição com todas as suas circunstâncias agravantes, endógenas e exógenas, de alucinaçōes e falsas interpretações; idéias de grandeza: o eu autofílico eleva-se tão absurdamente no seu auto-conceito, que perde inconscientemente a noção da relatividade de sua situação no meio; a percepção das impressões externas permanece perfeita durante muito tempo - são raras as alucinaçóes do ouvido e somente mais tarde aparecem as da vista etc.; falsos reconhecimentos de pessoas; as funçōes psíquicas resistem muito bem, sendo a demência um fenômeno raro e demorado nestes casos; os paranóicos são recriminadores e ameaçadores. De acordo com Juliano Moreira e Afrânio Peixoto, o diagnóstico diferencial seria facílimo: a primitiva e originária autofilia que a educação permitiu - ação e reação persecutórias - causa uma sistematização e idéias e de delírios coerentes, lógicos, fixos, com falsificação da memória chegando até às mudanças da personalidade; raridade de alucinaçōes; inteligência lúcida por longo tempo sem deterioraçōes demenciais. Por meio desse diagnóstico diferencial, torna-se possível separar a paranóia dos síndromas paranóides, que apresentam os múltiplos e profundos erros sensoriais comuns a todas as doenças mentais (Moreira \& PeIXoto, 1914). 
ção, a doença mental sempre se refere a uma lesão específica, em contraposição à generalidade causal do saber moral.

Em relação à sociogênese, os princípios básicos são os mesmos - a alienação mental é dada pela rede de relaçōes com os outros, e o alienado significa a quebra dessa rede, o não socializado. A alienação será o egoísmo, o oposto do socializável, do altruísmo necessários para a vida social.

Como explica Joel Birman (1978), tal rede representaria a sua máxima verdade, e se o alienado significa a quebra desta sociabilidade, devido à exacerbação de suas paixóes ou à pequena intensidade de seus afetos, ele é, por isso mesmo, encarado como obstáculo à comunhão social, ele é a própria impossibilidade da sociedade, da moral e da vida humana. Nesse caso, o homem normal e o alienado teriam uma mesma natureza, distinguindose apenas pela intensidade da manifestação dos seus afetos, numa diferença quantitativa que não os distingue em sua essência de seres definidos por seu caráter de sociabilidade. $\mathrm{O}$ conhecimento psiquiátrico, salienta Birman (1978), acompanha a formulação do conhecimento médico que postulava, conforme análise de Georges Canguilhem em Le Normal et le Pathologique (1966), que o estado patológico é uma variação quantitativa do estado normal, para mais ou para menos, não considerando esses dois estados como qualitativamente diversos. Tal concepção de estado patológico foi cunhada por François Broussais (1800) e universalizada por Auguste Comte (1828).

Birman (1978) esclarece a idéia de que, se entre o alienado e o homem sadio não há oposição qualitativa, mas quantitativa, o alienado se torna a caricatura do sujeito, revelando, assim, alguma verdade. Lugar de alguma verdade num primeiro momento, torna-se, entretanto, imediatamente a capacidade de sua destruição. "Nesse movimento reflexivo de colocar a alienação como caricatura da verdade num primeiro momento, e como a sua anti-verdade num segundo, pela quebra do mundo das normas, ela [a alienação] passa a se tornar, num terceiro momento, como a decadência última do sujeito" (Birman, 1978:113). A alienação será, portanto o egoísmo oposto ao altruísmo necessário para a vida social.

Com o conceito de 'predisposição', desenvolvido na teoria das degenerescências por Morel, o meio social será produto de doenças, mas não será produtor de doença por si só. Ele o será apenas na medida em que o indivíduo já nasce predisposto, isto é, com tendências a se desenvolver através de um processo patológico degenerativo. Do mesmo modo, o meio 
poderá ser o freio desse processo patológico, que se origina por uma tendência inata do homem, se lhe for dada uma educação saudável, se lhe for apresentado um meio social que lhe permita desenvolver uma personalidade normal, visto que "cada criança que nasce é socialmente comparável ao primeiro homem; o eu lhe é hipertrofiado e sem as restrições modificadoras seria comparável a um louco ou criminoso. É a educação que as submete e modifica, dando-lhes identidade social" (Moreira \& Peixoto, 1914:27).

A educação será, como no século XIX, o elemento positivo, no sentido saudável, que transforma o indivíduo em sujeito normal, disciplinado, em contraposição ao doente mental, indisciplinável. De acordo com essa abordagem, o meio social não será mais definido com base em seu aspecto negativo de patologia, mas em seu aspecto positivo de normalidade; o meio social será normalizador do sujeito, corrigindo-o dessa essência egocêntrica originária.

O tipo de relação do homem com o meio será determinante do estado mental saudável ou patológico. A relação considerada saudável do indivíduo com a sociedade é estabelecida a partir do critério de normalidade, obtido do conceito de socialização, que é um processo necessário à formação do indivíduo normal, mentalmente são. Para a psiquiatria, o desvio da normalidade é, neste sentido, a doença mental - idéia que, generalizada, no final do século $\mathrm{XIX}$, a todo indivíduo anormal, faz surgir o conceito médico da anormalidade. $\mathrm{O}$ discurso psiquiátrico torna o anormal patológico, ao mesmo tempo que o diferencia do 'verdadeiro doente mental' e do indivíduo normal.

$\mathrm{O}$ indivíduo normal é aquele que vive em sociedade, é aquele que se submete, desde a infância, ao processo de socialização. Nesse caso, a loucura é a não submissão à socialização, a rebeldia ao contrato social ao qual o indivíduo deveria aderir: por uma 'predisposição' dada, este nega tal contrato, entregando-se mais ao 'egocentrismo originário', incompatível com o altruísmo saudável, que não é natural, inato no homem, mas se faz necessário para o convívio em sociedade. Como afirma Juliano Moreira, "o altruísmo não é uma aquisição somática, é apenas uma espécie de contrato a que nos submetemos tacitamente ao partilharmos a vida social" (Moreira \& Peixoto, 1914:27).

$\mathrm{Na}$ teoria de Kraepelin, a loucura é a manutenção da essência negativa do homem, que é o egocentrismo originário. O meio social é, por meio da 
educação, o elemento modificador do sujeito na medida em que o submete à socialização e o corrige dessa tendência originária.

A educação compete corrigir essa tendência inata, num trabalho de adaptação ao meio social, que se inicia desde os primeiros anos de vida, por meio da convivência, do exemplo, da experiência cotidiana; não é, portanto, herdada.

$\mathrm{O}$ discurso psiquiátrico do início do século $\mathrm{XX}$ dirige-se à civilizaçāo, ao meio, como no século XIX, abordando os mesmos temas, mas deixará de fazê-lo do ponto de vista negativo, ou seja, da doença. Ela o fará norteada por seu saber sobre a saúde e sobre a normalidade, para o qual todo desviante, doente mental propriamente dito ou anormal, deve ser recuperado.

Nesse discurso, até mesmo a degenerescência pode ser vista positivamente, ou seja, como possibilidade de retorno ao normal, ao 'tipo comum':

\section{A degeneraf̧ão é uma estereotipia diagnóstica, quando não uma simples ecolalia de desig- nação, e que para contrapor aos casos sisudamente comprovados de derrancamento somático do individuo, hd a todos os momentos, esta obra de regeneraçäo da espécie que suprime o individuo, quando não logra corrigir-lhe as aberraçöes, integrando no futuro o tipo comum. (Moreira \& Peixoto, 1914:27)}

A normalidade biológica é uma concepção do século XIX que, trabalhada num nível teórico, se estabelece pelo tipo comum da espécie humana. A espécie é o padrão inexoravelmente imposto ao indivíduo, contra o qual ele não pode se colocar, na medida em que suas leis são tão fortes que, se houver degeneração, esta será corrigida - ou pela integração do indivíduo ao tipo comum, ou até mesmo por sua supressão. Contudo, o conceito da anormalidade como objeto da medicina mental só aparece como constitutivo do corpo 'científico' da psiquiatria, ainda que de modo obscuro, nas teorias psiquiátricas do início do século XX.

Para compreendermos com maior clareza essa noção de normalidade, podemos analisar, do ponto de vista teórico, a noção de paranóia explicitada no Brasil por Juliano Moreira. O objetivo de Moreira era definir com precisão esse conceito, a fim de elucidar o seu sentido como entidade nosológica, questão considerada importante no início do século $\mathrm{XX}$, sobretudo quando a paranóia passa a ser compreendida como critério de definiçăo da doença mental:

O problema atual é saber se a Paranóia na verdade apresenta caracteres que permitam ser considerada como uma entidade nosológica distinta, e, verificada tal hipótese, se a ela deve- 
se anexar a modalidade paranoia - querelante, ou se nada mais é do que uma modalidade da Demência Precoce das parafrenias, da loucura maniaco-depressiva, se éo delirio crônico de Magnam, ou a psicose alucinatória crônica de Gilbert Ballet ou o delirio crônico sistematizado de Henrique Roxo, enfim uma psicose dos degenerados. (Andrada, 1916:139)

Para efeito de análise do discurso psiquiátrico, essa questão é realmente importante. Não porque concluirá pelo estabelecimento ou não de uma nova classe de doença mental, mas porque a discute dentro dos limites da noção de sociabilidade, elegendo-a teoricamente como critério para definir a doença mental.

O primeiro aspecto abordado por Juliano Moreira é o desenvolvimento da personalidade paranóica. Existe um período 'predêmico' ou de elaboração da paranóia propriamente dita, que segue uma marcha própria: primeiramente há uma primitiva e originária autofilia: "sentimento inato e fundamental da personalidade - não corrigida e inadaptada ao meio, antes incrementada pela educação defeituosa resulta numa egocentria" (Moreira \& Peixoto, 1914:27).

Num segundo momento, "inadaptabilidade correspondente entre 0 indivíduo e o meio: interpretação como hostilidade pessoal" (Moreira \& Peixoto, 1955:27). Terceiro, reação contra o meio: "início das perturbaçōes aparentes. Perseguição ativa ou passiva, ou ativo-passiva mais comumente" (Moreira \& Peixoto, 1955:27).

Juliano Moreira afirma haver uma tendência geral a incriminar a degeneração como causa da paranóia, acrescentando que a doutrina da degenerescência desde que se apresentou a Morel só encontrou submissóes irrefletidas - ela existe, ela é profunda, a ela se deve grande parte de nossas misérias, mas, para ele, há um abuso em sua utilização.

Ele aceita a concepçáo de herança, conforme vimos anteriormente, mas só no sentido sociológico, quer dizer, acentuando a questão da adaptação do homem ao meio e responsabilizando-a pelas diferenças individuais. O problema da doença mental ocorre quando a personalidade não se adapta ao social, mantendo-se egocêntrica. O normal e o saudável resultam de uma educação tal que não permita desenvolverem-se os gérmens da autofilia, decorrentes do egocentrismo originário que, na criança, como já foi dito, lhe permitem a sobrevivência, mas no caso do adulto é compreendido como doentio. 
A noção de equilíbrio do comportamento do homem com o meio social é que definirá a saúde mental. $O$ equilíbrio social, a harmonia, será o critério determinante da saúde; o desequilíbrio, a luta contra a socialização, será doença mental. Juliano Moreira atribui como causalidade da paranóia a manutenção, por erro de educação, desse estado egocêntrico primitivo, separando-a de uma causalidade sensorial ou de erro da consciência.

A separação da etiologia do distúrbio mental como distúrbio intelectual e sensorial é bastante clara. A causalidade é efetivamente social. Os sintomas e o diagnóstico diferencial o revelam:

Sintomatologia: reconbecimento da hostilidade do meio que produz em certos paranóicos reaçōes depressivas, de humor irregular, de indefinido mal-estar, acompanhado de inapetência $e$ de insônias. Suscetibilidade extrema que chega à sujeiçäo completa, como defesa às bostilidades do meio. Idéias de grandeza: o eu autofilico eleva-se tão absurdamente no seu auto-conceito que perde inconscientemente a noção da relatividade de sua situação no meio. A percepção das impressöes externas permanece perfeita durante muito tempo - são raras as alucinações do ouvido (mais comum) e somente mais tarde as da vista, etc. (...) a demência é um fenômeno raro e demorado nestes casos. Recriminantes e ameaçadores. (Moreira \& Peixoto, 1914:27)

A demência, fenômeno explicitamente de distúrbio da inteligência, é por Kraepelin e Juliano Moreira separada, em termos de nosologia, da paranóia:

Diagnóstico: primitiva e originária autofilia que a educação permitiu; ação e reaçāo persecutórias; sistematização de idéias e de delírios coerentes, lógicos, fixos, com falsificação da memória chegando até as mudanças da personalidade; raridade de alucinaçōes; inteligência lúcida por longo tempo sem deterioraçōes demenciais. (Moreira \& Peixoto, 1914:27)

A demência paranóide será considerada uma síndrome da paranóia, mas não uma característica fundamental desta doença, como é o caso da demência precoce ou mesmo da demência senil:

Nos primeiros e superficiais exames certas formas de demência precoce, as paranóides, poderiam dificultar a diagnose diferencial. A multiplicidade de alucinaçōes, a incoerência e absurdeza do delirio e os indices bem notáveis de enfraquecimento mental traçam quase sempre, ou em breve espaço, uma separação bem clara. (Moreira \& Peixoto, 1914:27)

O que importa, em relação a essa questão do reconhecimento da paranóia como entidade nosográfica, é que, dessa maneira, a teoria psiquiátrica revela a sua percepção da doença mental, em geral, independentemente de sua classificação num quadro nosográfico específico. Ao ser comparada à paranóia e atribuída aos casos mais dessemelhantes de distúrbios psíquicos, a doença mental passa, praticamente, a constituir a própria noçâo de paranóia. 
O termo 'paranóia' tem sido aplicado às mais diversas psicopatias, para designar síndromes mentais de perseguição. Há uma confusão que não se esclareceu; ademais, surgiram paranóias de todos os tipos - aguda, crônica, abortiva, rudimentar, primária, secundária, erótica, religiosa etc. Paranóia veio quase a equivaler à expressão loucura, afirma Bueno de Andrada em seu artigo 'Paranóia' (1916).

Em suma, no início do século XX tenta-se esclarecer a percepção da loucura por meio do conhecimento científico sobre a causalidade da doença mental, que com Juliano Moreira abre, no Brasil, o espaço do desvio e da exceção, mesmo quando já estabelecidas entidades clínicas que pretendem abarcar todas as perturbaçóes mentais encontradas, pertinentes a vários grupos clínicos. Isso permite que surjam novos diagnósticos para comportamentos que começaram a ser considerados perigosos, como é o caso dos alcoólatras, epiléticos, querelantes e sifilíticos, agora tornados objeto da psiquiatria. $\mathrm{O}$ estudo científico da sífilis, do alcoolismo e outras intoxicaçóes involuntárias servirá de base para as análises sobre a doença mental, considerada entrave ao progresso social da humanidade.

Tais diagnósticos oferecem ao discurso teórico psiquiátrico uma flexibilidade, ainda maior do que no século XIX, ao campo da medicina mental, permitindo a que seu discurso se aplique tanto do ponto de vista orgânico como no social, de modo a facilitar a passagem de um tipo de argumentação a outro, conforme seja mais conveniente. Se o problema apresentado se referir à exigência de uma fundamentação médica, há métodos de diagnósticos, como a punção lombar, efetuada pela primeira vez no Brasil por Juliano Moreira, sem os quais, em sua opinião, muitas vezes ficaria incurável o paciente. Demonstra-se, assim, o substrato físico da doença mental, no caso a sífilis, considerada a pior de todos as infecções que causam distúrbios psíquicos, chamados de males do sistema nervoso. Em 'A psiquiatria e a guerra', Juliano Moreira explicita tal etiologia: "As doenças venéreas, assim como as células nervosas de resistência diminuída pela impregnação alcóolica, são responsáveis por muitos males no sistema nervoso" (Moreira, 1918:122).

O alcoolismo, por sua própria definição, favorece uma mudança na relação estabelecida entre o elemento físico e o moral. $O$ alcoolismo crônico tem uma variedade clínica que se exterioriza em forma de delírio persecutório com idéias de crimes, alucinações múltiplas e perturbações da sensibilidade geral. Os alcoólatras perseguidos são reconhecidos como auto-acusadores, 
que se queixam contra todo o pessoal que os cerca, pedindo proteção sem contudo procurar reagir contra seus supostos inimigos. $O$ quadro do delírio persecutório é ligado ao problema da degeneração. "Evidentemente esses são casos de sujeitos degenerados nos quais o alcoolismo apenas cria o aparecimento de delírios complexos, após os psicopatas constitucionais (degenerados e desequilibrados dos psiquiatras franceses)" (Moreira, 1912b:325).

Se a questão se apresentar com vistas a assegurar algum projeto assistencial ou político, esse tipo de discurso permeável se torna mais simples, passando de um ponto a outro, pois são doenças tomadas quanto ao componente de implicação com o social, porque são "endemias sociais das mais daninhas" (Moreira, 1929b:61), que constituem problemas psiquiátricos correlatos às questôes sociais: "um problema concernente ao estudo dos fatores de desenvolvimento físico e intelectual das raças (...) é preciso lembrar os perigos individuais, hereditários e sociais que derivam da sífilis" (Moreira,1899-1900:112).

Como tal, oferecem subsídios ao movimento de higiene mental ${ }^{53}$ que começa a aparecer no Brasil. Os psiquiatras apontam a grande preocupação dos estadistas com a freqüência de certas doenças - tuberculose, câncer, sífilis, impaludismo etc. -, com a finalidade de alertá-los quanto às perturbações nervosas, cada dia mais freqüentes, devido à crescente propagação dessas doenças, às quais se deve somar o problema do alcoolismo, um dos principais fatores sociais que preparam a eclosão dos distúrbios mentais. Concluem daí que o alcoolismo, entidade nosográfica de Kraepelin incluída na classe das intoxicaçōes voluntárias, merece que se inicie uma campanha enérgica nos domínios da profilaxia mental em nosso país. Essa campanha vai ao encontro do "progresso ininterrupto da psiquiatria, da assistência aos psicopatas e, sobretudo, da Higiene Mental" (Moreira \& Austregésilo, 1923:55).

O que importa assinalar é que essas classificaçōes são, na realidade, tentativas de justificar em termos médicos a inclusão de novos grupos

\footnotetext{
${ }^{53}$ Em 1923, funda-se a Liga Brasileira de Higiene Mental, pelo psiquiatra Gustavo Riedel, com o objetivo de melhorar a assistência aos doentes mentais; a partir de 1926 visa à prevenção, à eugenia e à educação dos indivíduos normais inclusive, permitindo um controle permanente. Traçando planos de prevençáo, cientificamente fundamentados no conhecimento das causas da alienaçăo mental, constitui um reforço para o poder disciplinar global, cuja tendência é intervir preventiva e permanentemente.
} 
nosológicos no saber psiquiátrico, que se referem a indivíduos que os próprios psiquiatras não consideram alienados, mas por um novo critério, o da anormalidade, os situam no quadro dos doentes mentais. As classificaçōes aparecem como garantia médica, já que a medicina mantém um procedimento taxonômico para imposição da psiquiatria como saber científico. ${ }^{54}$ Situar a psiquiatria cientificamente era, na época, de grande importância, pois viabilizava sua interferência na sociedade e validava um projeto político no qual é a patologia que oferece o modelo de análise, assim como a medicina legal lhe dá a possibilidade de intervir - por meio da psiquiatrização dos diferentes desvios sociais e da infância.

É na esteira desse movimento de penetração da medicina mental em toda a rede de relaçōes de poder instaurada em nossa sociedade que Juliano Moreira discute o problema dos falsos testemunhos por desvios mentais. Ao afirmar que, enquanto para os homens normais o erro é um elemento constante do testemunho, "aos que apresentam perturbaçōes mentais, as revelaçōes devem ser pelo menos ouvidas com suspeitas". Pautado pelo parecer de eminentes juristas, médicos-legistas e alienistas, assim como pelo voto de vários congressos, Juliano Moreira afirma que "os magistrados devem apelar para o concurso de um médico alienista sempre que se possa suspeitar em qualquer testemunha um estado mental mórbido" (Moreira, 1912b:325).

Seu argumento é o seguinte: são numerosos os doentes que vão à polícia, aos jornais, ao Ministério da Justiça e até ao chefe de Estado denunciar

\footnotetext{
${ }^{54}$ Ao traçar, na História da Loucura, uma descontinuidade histórica entre a psiquiatria na época clássica e a psiquiatria na modernidade, Foucault caracteriza a primeira como um conhecimento classificatório, cujo método baseia-se na história natural, na medicina das espécies ideais, que não parte da observação do louco, nem incide no processo de internação sobre o qual a psiquiatria procurará, mais tarde, apoiar seu conhecimento. Como explica Roberto Machado (2000), a pesquisa arqueológica de Foucault pensa o que é o moderno, situando-o em relação ao clássico. "Na História da Loucura isso levou a duas descobertas fundamentais ou à descoberta de descontinuidade, de uma grande ruptura em níveis diferentes: o das teorias sobre a loucura e o das práticas que dizem respeito ao louco. Mais precisamente, um nível em que preponderam as teorias, outro, em que preponderam as práticas, pois a esse respeito a separação não é total. O fundamental é a existência da loucura sob o olhar da razão, ligando-se a um sistema de operaçōes médicas relacionadas aos sintomas e às causas e, em outro nível, por sinal mais elementar, do louco situado do outro lado da razáo, ligando-se a concepçóes políticas, jurídicas, econômicas" (MACHADO, 2000:15). É assim que Foucault enuncia uma das teses mais importantes da História da Loucura, que $e_{\text {a }}$ independência, na época clássica, dos níveis das teorias sobre a loucura e das práticas com relação aos loucos.
} 
a si mesmos ou a outrem, e o fazem porque são doentes. ${ }^{55}$ Dentre eles, os que dão mais freqüentes falsos testemunhos são os maníaco-depressivos, que atacam a reputação, a honra e a moralidade de todos aqueles que os cercam com precisão de detalhes e muita persistência: "São doentes dessa natureza que têm publicado todos os livros de fama duvidosa contra manicômios e alienistas. São eles que desde tempos imemoriais mais amedrontam o pessoal dos asilos" (Moreira, 1912b:325). Ele ressalta também os dementes senis e pré-senis, cujas idéias persecutórias são acompanhadas de acusaçōes contra pessoas da própria família.

$E$ inesgotável o repositorio médico-legal de tais doentes, com as suas acusaf̧öes falsas, sendo muito mais freqüentes as hetero-acusaçöes. Mais interessantes porém, que uns e outros, são os casos mistos, isto é, os de auto-hetero-acusadores, quase sempre de ordem genital. São os romances criminais de duplo herói, é a culpabilidade a dois. $O$ famoso caso Morele-la Roncière, com as suas imemordveis cartas anônimas, simulaçäo de tentativa de violação e assassinato por um jovem de dezesseis anos pertencente d̀ melhor sociedade, erro judiciário e condenaçāo consecutiva, é de ordem a pôr em guarda juizes e jornalistas. (Moreira, 1912b:325)

A classificação tem a função não só de possibilitar a organização do espaço asilar, de assegurar cientificamente o poder e a autonomia do psiquiatra, mas, antes de tudo, de controlar os próprios psiquiatras para que, normalizados eles mesmos, possam impor seu saber às diversas instâncias da sociedade.

O modelo teórico de Juliano Moreira faz parecer que o ponto de partida para a constituição do saber psiquiátrico que inaugura é o conhecimento cada vez mais científico da loucura como doença mental, do qual se infere um conhecimento sobre o anormal em geral. Mas é preciso reconhecer, para melhor compreender esse modelo teórico, que foi partindo da percepção da periculosidade e da não sujeição à ordem disciplinar, que representam os anormais, que a psiquiatria elaborou sua teoria. ${ }^{56}$

5s As categorias de insanos apontadas por Juliano Moreira como compostas por aqueles que mais fornecem falsos testemunhos são: maníaco-depressivos, paranóicos, dementes senis e pré-senis, alcóolicos e outros intoxicados, psicopatas constitucionais (segundo Dupré, aqueles com tendência mórbida, mais ou menos consciente e voluntária, à mentira e à criaçāo de fábulas imaginárias), débeis mentais, epilépticos, sifilíticos (devido ao modo como perdeu as noçōes mais elementares do senso moral) (MOREIRA, 1912b).

${ }^{56}$ Cumpre notar que Foucault afirma, em História da Loucura (1972), que a designação de loucura e a conseqüente exclusão da sociedade não dependem de uma ciência médica, mas de uma 'percepçáo' do indivíduo como ser social, dispersa e produzida por diversas instituiçōes como a polícia, a Justiça e a família, com base em critérios que dizem respeito à transgressão das leis da moralidade. 
Com Juliano Moreira, inaugura-se no Brasil um novo momento do saber psiquiátrico. Ao se introduzir um modelo teórico que tenta atribuir lesóes específicas aos diversos tipos de doença mental e refere-se não só ao louco mas a outros tipos de desviantes, os anormais, estabelece-se uma descontinuidade em relaçáo à generalidade causal das teorias morais do século XIX e em relação ao seu objeto. A psiquiatria não é mais o discurso científico sobre a loucura e suas causas somente: ela é o saber médico sobre todo desvio da normalidade - criminalidade, degeneração, doença mental. 


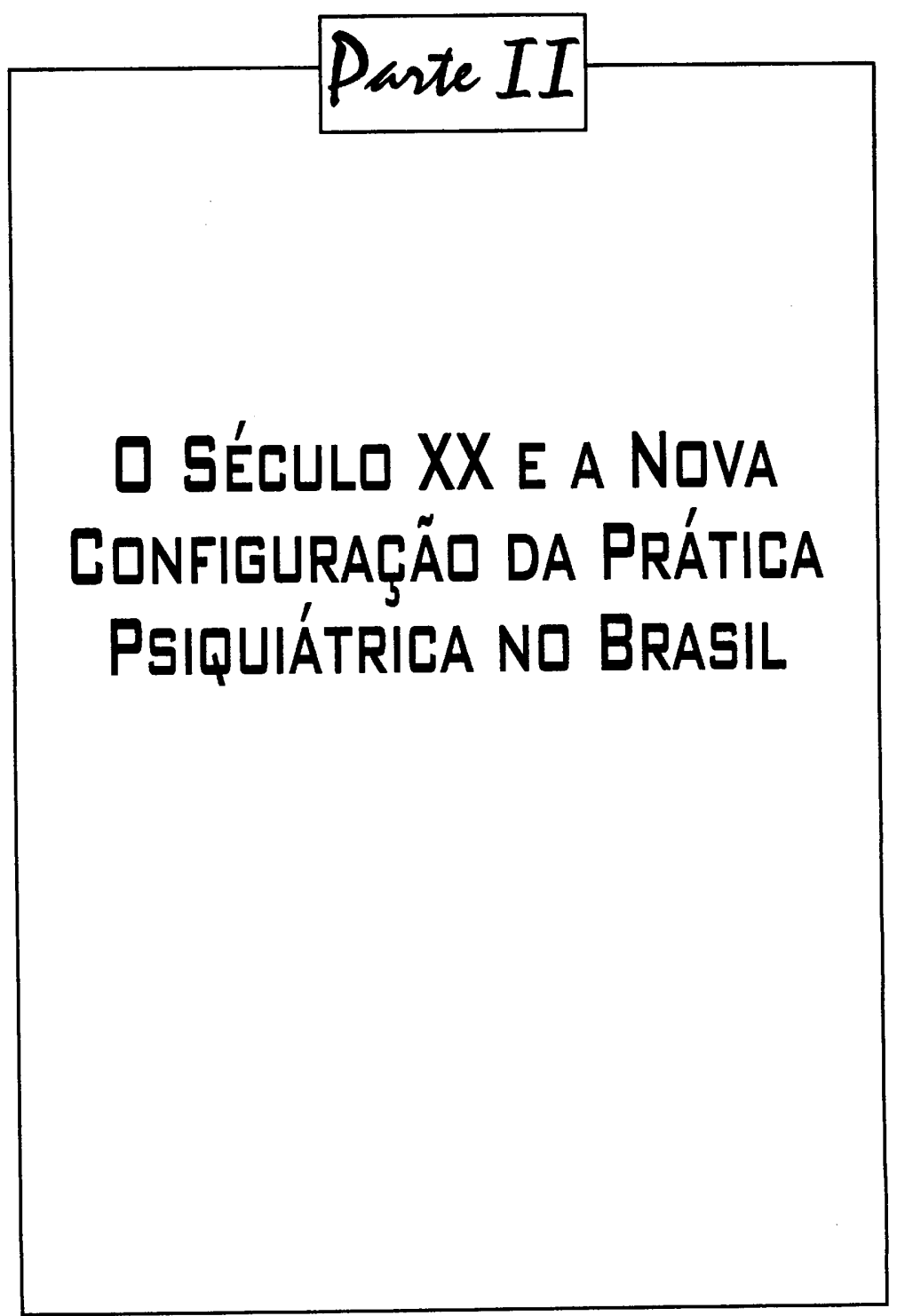


A op̧̧ão de lutar contra a exclusão social, que trinta anos atrás era uma op̧̧ão de poucas pessoas, se inscreve hoje na consciência geral da comunidade internacional. Mas isto não quer dizer que seja traduzida em práticas coerentes em todos os lugares. Ao contrário, 0 fenômeno de exclusão social é cada vez mais grave e difuso.

Cooperação Internacional pelo Desenvolvimento Humano,

No final do século XIX, a função do psiquiatra brasileiro era ainda bastante limitada, apesar da luta dos psiquiatras para se imporem como elementos necessários à manutenção da ordem social e da criação, desde 1830 , do hospício. A situação dos loucos, embora já percebida como carente de cuidados médicos especiais e relativamente mais próxima das reivindicações dos médicos alienistas - não deveriam mais perambular pelas ruas e lhes era destinado o hospício em vez de serem "enviados às horrorosas enfermarias da Santa Casa de Misericórdia” (Moreira, 1955:65) - era ainda considerada ultrajante.

Com o início da República, verifica-se a necessidade de reformulação do asilo, a fim de melhor cumprir suas funçóes terapêuticas, e, para tal, reforçar o papel do médico no exercício de total poder sobre os alienados, tanto na determinaçáo de quais eram os indivíduos doentes quanto na decisão sobre o melhor encaminhamento a ser dado a cada um deles. Teixeira Brandão (1956) exige uma posição de mais poder, mais autoridade para o 
médico, que deveria ser colocado na posição central em relação a tudo que se referisse à vida do louco, para transformar o hospício em verdadeira instituição hospitalar.

O movimento de 'medicalização' do louco caracteriza a funçáo dos psiquiatras do século XIX, que criticam a insuficiência e ineficácia do hospício, mostrando a necessidade de multiplicaçáo de instituiçóes articuladas, amparadas por uma lei que desse aos hospícios a exclusividade de seqüestração do louco e regulasse a sua situação na sociedade.

A principal crítica dos psiquiatras do século XIX dirige-se à questão da admissáo do louco no hospício. Todos os problemas relativos a essa questão - direito de sequiestração, a relação entre o louco e a família, entre o louco e a Justiça, o louco e a psiquiatria, o louco e o Estado - tornam-se de particular importância para a assistência ao alienado. Eles constituirão pontos básicos para a transformação da prática psiquiátrica no Brasil.

A medicalização não significa, portanto, apenas reconhecer a qualidade de doente do louco ou a transformaçāo do hospício em estabelecimento médico semelhante a um hospital, mas implica a definição, pela instituição médica, de um novo estatuto jurídico, social e civil do alienado: o estado de menoridade social.

Teixeira Brandāo discute, no final do século, as dificuldades para se resolverem tais problemas, pois sua solução pressupõe uma situação inexistente na sociedade; ela exige a presença especializada de um médico na família, na administração e na Justiça.

Reconhecia-se que a exigência de medicalização no hospício remetia à medicalização da sociedade inteira. $O$ que não significou, na época, que Teixeira Brandão propusesse um modelo não asilar de gestão da loucura, como ocorrerá mais tarde com o modelo de Juliano Moreira, pois o hospício era visto como centro da psiquiatria do século XIX.

Com o objetivo de transformar o asilo numa 'instituição fundamental' para a psiquiatria, Teixeira Brandão assinala que é preciso uma lei que defina as condiçóes de seqüestração do louco no asilo, considerando arbitrária qualquer internação não sancionada pelo alienista. A psiquiatria é a única capaz de fazer do seqüestro um ato não-arbitrário, devido a seu saber sobre a loucura. Ele reconhece o problema que o louco representa para as 'autoridades' e aponta o saber psiquiátrico como a única possibilidade de resolver 
a contradição do seqüestro: internar o louco se apresenta ao mesmo tempo como necessidade social, para a defesa da coletividade, e como injustiça, pois atenta contra o princípio de liberdade individual, base da organização social da República. O psiquiatra oferecerá uma resposta a essa contradição ao se transformar em instância definidora do estatuto do louco, como doente e como incapaz, como sujeito a ser tratado e protegido por uma lei medicalizada, ou seja, uma lei elaborada a partir do saber da medicina mental.

Daí a exigência de que a incapacidade do louco seja cuidadosamente regulada pela psiquiatria, que dará ao alienado não somente o estatuto de doente mas também de menor, ao estabelecer que ele deve delegar sua vida a um elemento idôneo. Essa regulamentação deverá se apoiar numa lei nacional, evidentemente medicalizada.

Em 1903, Teixeira Brandão é eleito deputado, conseguindo no mesmo ano a aprovação da lei dos alienados, que faz do hospício o único lugar apto a receber loucos, subordinando sua internação ao parecer médico.

A lei estabelece a guarda provisória dos bens do alienado, determina a declaração dos loucos que estão sendo tratados em domićlio, regulamenta a posição central da psiquiatria no interior do hospício, subordina a fundação de estabelecimentos para alienados à autoridade do ministro do Interior ou dos presidentes ou governadores dos estados, cria uma comissão inspetora de todos os estabelecimentos de alienados. Essa lei faz do psiquiatra a maior autoridade sobre a loucura nacional, e publicamente reconhecida.

A questão que surge com a lei de 1903 e a separação entre o hospício e a Santa Casa é a da legitimação da estatização do hospício. Transferir para o Estado a responsabilidade pelos asilos destinados ao louco parece, para os psiquiatras da época, legítimo e necessário. $O$ Estado garantiria a segurança da sociedade, defendendo a coletividade dos possíveis abusos cometidos pelos doentes mentais, considerados incapazes de gerir sua própria pessoa e seus próprios bens. Isso porque o Estado é superior às confrarias, à família $\mathrm{e}$ a qualquer estabelecimento particular. Portanto, só o Estado deveria ter o direito de exercer o poder de sequiestração, apoiado no saber e na prática psiquiátricos, para que o internamento na instituição asilar não se transformasse em pura exclusão repressiva.

Juliano Moreira encaminhará uma forte luta pela elaboração de uma lei federal de assistência aos alienados, insistindo com o governo na necessidade 
de solicitar do Congresso a sua promulgação. ${ }^{57}$ A questão que se coloca, então, é como conciliar o regime federativo, instituído após a proclamação da República, com uma lei federal de assistência. Juliano Moreira vê a possibilidade de cada estado regulamentar seus manicômios e, ao mesmo tempo, obedecer a uma lei federal..$^{58}$

Já em 1903, a Comissão de Saúde Pública da Câmara, tendo como relator Teixeira Brandão, havia aprovado mensagem do Executivo sobre a assistência a alienados. Em dezembro desse ano é promulgada a lei federal de assistência a alienados. Essa lei, decretada no governo Rodrigues Alves, de marcada atuação das questōes da saúde pública, representa mais uma conquista do processo de 'psiquiatrização' dos alienados, cujo principal representante é Juliano Moreira, nomeado em 1903 para a direção do Hospício Nacional dos Alienados e para a direção geral da Assistência a Psicopatas, cargo que ocupará durante 23 anos.

O processo de 'psiquiatrizaçāo' do alienado corresponde ao objetivo da normalização do louco por meio de uma política de saúde mental. Sem dúvida, tal política articula um código teórico (as nosografias), uma tecnologia de intervenção (terapia), um dispositivo institucional (o asilo), um corpo de profissionais (médicos) e um estatuto do usuário (menoridade do alienado), além dos pagantes, promotores, pedintes.

No início do século $\mathrm{XX}$, as investidas de psiquiatrização ganham força com Juliano Moreira, que trabalha para instaurar um modelo de assistência capaz de tornar homogênea a intervenção médica que incide sobre os indivíduos tidos como inúteis, loucos, desordeiros e prejudiciais ao bem-estar social, sempre na perspectiva de responsabilizar o Estado por essa função. Para isso, tenta instituir um controle centralizador e diretrizes uniformes de conduta em relação a esses indivíduos que ameaçam a ordem disciplinar da sociedade.

${ }^{57} \mathrm{Em}$ 'Quais os melhores meios de assistência aos alienados', Juliano Moreira apresenta tal exigência: "submeto ao vosso esclarecido juízo as bases de uma reforma do Hospício Nacional de Alienados. Seja-me porém permitido antes de tudo lembrar que entre os serviços prestados à causa pública de maior relevância aquele que consistir em dotar o Brasil de uma lei geral de assistência a alienados" (MOREIRA, 1910:373).

s\& No 'Relatório da Comissão de Inquérito sobre as condiçōes de assistência no Hospício Nacional e colônias da Ilha do Governador - legislação sobre a assistência a alienados', Nina Rodrigues propõe o um sistema legal que respeita o regime federativo: "Sua adoção de nenhum modo resultará uma lesão do regime federativo sob o qual vivemos, por isso que a cada estado ficará o direito de, sem prejuízo dos princípios naquele exarados, regulamentar a seu modo seus respectivos manicômios" (RODRIGUES, 1906:365). 
É nesse contexto que o saber classificatório da psiquiatria passa a ser inserido na prática psiquiátrica, isto é, assim pode ser compreendida a importância de uma classificação das doenças mentais com mais 'uniformidade', conforme se pretende na época. Assim, Juliano Moreira insiste num novo plano de trabalho: "O multiplicar intérmino de classificaçōes, as diversas tentativas de vários congressos de alienistas e de várias sociedades de psiquiatria do mundo, demonstram que para maior proveito de nossos estudos há vantagem em adotar um plano de trabalho até certo ponto uniforme" (Moreira, 1919:39).

A classificaçáo começa a ser vista como um instrumento médico-científico para a açáo do Estado voltada para um maior controle da população e da saúde, por meio da definição que torna patológicos os indivíduos desviantes do padrão de normalidade, isto é, que ameaçam a disciplina da sociedade. Efetivamente, só se elabora um plano uniforme e definitivo de classificação quando o Estado o exige; só se estabelecem com um pouco mais de clareza as classes nosográficas da alienação quando os artigos do Código Civil relativos à incapacidade mental precisam ser explicitados, no que tange à expressão 'loucos de todo gênero', que constava em tais artigos até 1920, ocasião em que os psiquiatras ainda reclamavam por uma classificação das doenças mentais (Moreira, 1920b). Em 1919, Juliano Moreira apresenta um plano de classificação ${ }^{59}$ da seguinte forma:

Em 1910, porém, a Repartição Geral de Estatística, desejando adotar em seus inquéritos uma classificaçāo de doenças que reunisse um maior número de adeptos, pediu conselho ao presidente e vice-presidente da nossa Sociedade. ${ }^{60}$ Este último [Dr. Eiras] lembrou que ainda não nos haviamos desobrigado da incumbência de que nos investiram os confrades na referida sessäo. Por insistência do colega Austregésilo e anuência do resto de nossa comissäo, relato eu hoje o nosso quesito. (Moreira, 1919:40)

A exigência, por parte da Repartição Geral de Estatística, de uma classificação uniforme se explica pelo fato de constituírem os dados estatísti$\cos ^{61}$ uma modalidade de controle, institucionalizada por um órgão criado para a fiscalização da própria psiquiatria. Trata-se de uma necessidade que se

${ }^{59}$ Curiosamente, nesse mesmo texto aparecem apenas consideraçōes sobre as diversas classificaçōes existentes, mas a sua classificação propriamente dita não aparece; aliás, ela não foi afinal encontrada em nenhum dos arquivos ou teses.

${ }^{60}$ Juliano Moreira refere-se à Sociedade Brasileira de Neurologia, Psiquiatria e Medicina Legal, fundada em 1908, ano em que foi designada uma comissão da mesma sociedade para apresentar um projeto de classificaçáo que servisse de base às estatísticas dos manicômios.

${ }^{61}$ A estatística médica se baseia na consideração da temporalidade que "permite registrar o acúmulo de sinais observáveis em dado período, de que devem surgir regularidades específicas. 
impõe durante muitos anos, pois sem que a psiquiatria esteja ela mesma disciplinada, não conseguirá disciplinar a população. Ainda em 1940, vinte anos mais tarde, cria-se a Divisão de Assistência à Psiquiatria, organismo federal subordinado ao Departamento Nacional de Saúde, que tinha como função, 'entre outras', a de fazer levantamento de dados estatísticos em todo o país com o fito de desenvolver a açăo supletiva da Uniāo (Peres, 1938-1939).

O registro, as estatísticas e a nova disciplina constituem justamente pontos de controle para a disciplina e a regulamentação da população, além de fornecerem à psiquiatria elementos capazes de torná-la mais abrangente, mais geral, na medida em que reúnem um grande número de dados para a elaboração da teoria sobre a doença mental, e, ao mesmo tempo, a tornam mais específica, na medida em que permite analisar cada caso na sua especificidade.

A partir de 1920, os psiquiatras brasileiros compreendem que a relação da medicina mental com a legislação impóe uma definição mais precisa da natureza da alienação, e a questão de sua revisão provoca não só o debate científico sobre o louco propriamente dito e os diversos tipos de desviantes a serem incluídos na classe de incapazes mentais, mas também um esforço para relacionar a prática psiquiátrica com a teoria da doença mental.

Juliano Moreira aparece, para seus contemporâneos, como aquele que conseguiu fazer corresponder a teoria à prática. ${ }^{62} \mathrm{~A}$ partir de Juliano Moreira, as questōes de cunho científico - como conceito de doença mental, critérios de classificação, embasamento médico e terapêutico etc. - começam a ser debatidas e, sobretudo, trazidas tanto quanto possível para a prática psiquiátrica, agora com a preocupação de investir na criação de um novo sistema de assistência ao alienado, que esteja mais de acordo com o programa de ordenação social do governo Rodrigues Alves.

Periodicidade minuciosa e singular, mas regrada, que implica em reunir ordenadamente". (MACHADO et al., 1978:261).

${ }^{62}$ Em 'Professor Juliano Moreira', texto anônimo de Arquivos do Manicômio Judiciário, essa função de Juliano Moreira parece ser reconhecida: "O magnífico sonhador da cura da alienação mental e sentindo que a consecução dessa tarefa exigia a compreensão das suas causas e dos seus mecanismos, incrementou a pesquisa, orientou estudos e verificaçōes que formam hoje grande parte da notável bibliografia brasileira concernente à patologia mental, investigou a natureza dos fatos clínicos, estudou e difundiu doutrinas e conceitos, interessando em todas essas questōes discípulos e colaboradores e fazendo do Hospital Nacional de Alienados um respeitável núcleo de trabalhadores, cientistas e professores" (Professor Juliano Moreira, 1933:3). 
$\mathrm{Na}$ nova estratégia do governo, a urbanização das cidades e os projetos sanitários aparecem como prioritários, e visam a um maior controle da ordem social, entáo abalada por antagonismos entre os diversos setores da população, e por manifestações das classes populares.

Os projetos sanitários caracterizavam-se fundamentalmente pela prevençăo. Eles foram elaborados com vistas à atuaçăo no campo da saúde física $e$ mental. É nessa época que Oswaldo Cruz é nomeado diretor do Instituto de Manguinhos para pesquisa das principais endemias do Brasil, e Juliano Moreira, diretor geral da Assistência Federal a Psicopatas, antes Assistência a Alienados, que, a partir de 1903, inclui os desviantes perigosos.

Essa extensão ao campo da saúde mental corresponde ao projeto de normalização e medicalização da sociedade - funçăo que a psiquiatria se atribui desde o século XIX, por causa de seu conhecimento médico, capaz de esmerilhar os problemas da alienaçáo e os debates sobre medidas práticas de combate às doenças, à falta de higiene, ao grande contingente de improdutivos e à alta taxa de criminalidade. Tais problemas surgiram como empecilhos para a implantação de um projeto de Estado mais forte, ou seja, com maior poder disciplinar, que viesse a responder às exigências do modo de produção capitalista iniciado com a República, em que o trabalho é assalariado e não mais proveniente da mão-de-obra escrava.

A prática psiquiátrica apontará novas normas de conduta, necessárias ao controle de uma sociedade burguesa, capitalista, feito por meio da higiene dos asilos, de uma nova ordenação dos doentes e de um esquadrinhamento da população. $O$ esquadrinhamento da população resulta de uma reflexão médica analítica, que a divide fundamentalmente em normais e doentes mentais, ou seja, em úteis, produtivos, e inúteis, doentes - divisão estabelecida desde o século XIX - e ainda em anormais, categoria médica do século $\mathrm{XX}$ referente aos desviantes em geral. ${ }^{63}$

${ }^{63} \mathrm{Em}$ A Idade de Ouro do Alienismo (1976), Castel indaga as razóes dessa cumplicidade da medicina e da administração e da diminuição correlata de um papel direto de intervenção da justiça e da polícia. Sua análise remete à questão da sociedade contratual, da livre circulação das mercadorias e dos homens, da diferenciação de normas de sujeiçāo dos sujeitos normais de uma sociedade racional. Remete à passagem da sociedade contratual para a tutelarização, processo no qual a medicina foi um operador essencial, a partir da questão da loucura. Ela produziu, na França, o estatuto médico-jurídico-administrativo do alienado sancionado pela lei de 30 de junho de 1838, a partir da qual os loucos foram considerados completamente loucos - entregues a profissionais estritamente especializados - e os normais, completamente normais. Essa atividade profissional de especialização expandiu-se, e, hoje, um número cada vez maior de decisões em 
Dessa forma, a prática psiquiátrica do século XX confere um caráter médico a outras instâncias da sociedade, de onde podem surgir os anormais. Mas essa medicalização é diferente daquela própria à psiquiatria do século XIX. Enquanto que, no século XIX, a medicalização das outras instâncias sociais está subordinada à medicalização do hospício, a partir de Juliano Moreira ela se exerce como sendo ela mesma um aspecto fundamental da prática psiquiátrica, na medida em que é necessária não apenas como auxiliar na medicalização do hospício, mas por ser imprescindível para debelar previamente o problema de alienação mental, presente em todas as instâncias da sociedade. Enquanto que no século XIX a prática psiquiátrica é uma ação restrita à psiquiatrização do hospício e às medidas necessárias à sua realização, no século XX a medicalização das outras instâncias sociais origina novos espaços terapêuticos e preventivos, criando um sistema de assistência totalmente novo.

Está claro que há ainda um esforço por parte dos psiquiatras para tornar o hospício um espaço médico, com o estreitamento da relação da teoria com a prática e, sobretudo, pela utilização de novas técnicas médicas, pois tal tarefa não foi dada por cumprida. A relação entre teoria e prática - ou seja, aplicar à prática preceitos médico-científicos e a partir dela obter elementos para a elaboração teórica - é uma exigência que só começa a se explicitar com Juliano Moreira. Tal relação resulta, no século XX, na necessidade de se dissociar a medicina científica da assistência, mantendo-se nos hospícios somente os 'verdadeiros doentes', assim chamados por ser a alienação considerada uma doença como outra qualquer, que deve ser tratada com meios que se aproximem ao máximo da medicina comum, em lugares que se pareçam com outros hospitais. Em 'Quais os melhores meios de assistência aos alienados', Juliano Moreira afirma que eles devem ser tratados intensivamente, por meio de um arsenal moderno para o 'tratamento racional' das doenças mentais agudas, implantado no Hospício Nacional: banheiras em número proporcional aos doentes, em salas vizinhas às que servem para o uso da clinoterapia, pavilhóes separados de acordo com o tipo e grau de doença, atendimento de enfermeiros na proporção de pelo menos "um para cinco doentes" (Moreira, 1910:383), laboratórios de anatomia patológica etc.

setores cada vez mais numerosos da vida social e pessoal são tomadas a partir de avaliaçōes técnico-científicas produzidas por especialistas competentes. "Sem dúvida, não há um limite determinável para esse processo" (CASTEL, 1972:20-22). 
Medicalizar o hospício e o louco já não é mais objetivo único da psiquiatria, embora continue sendo uma meta importante, conforme se pode inferir das reivindicações de Teixeira Brandão. Torna-se fundamental a psiquiatrização não somente do louco propriamente dito, mas do louco em potencial, representado por todo e qualquer indivíduo normal, na medida em que este pode, por um processo de degeneração, adquirir uma doença mental; e, principalmente, dos anormais, degenerados - alcoólatras, epiléticos, sifilíticos etc. - mais vulneráveis e sujeitos, pela decadência moral e degenerescência física, à loucura. A psiquiatria começa a dedicar seu saber ao conhecimento da anormalidade, dos desviantes - criminosos e degenerados.

Toda a anormalidade passa a ser percebida como um desvio mental. Ela é medicalizada, isto é, submetida à racionalização terapêutica para deter, cuidar, corrigir e reeducar, assim como ocorreu, no século XIX, com a loucura. $\mathrm{O}$ conceito de doença mental, que se deve à percepção da loucura como um comportamento indisciplinável, se estende a todos os outros tipos de comportamento indisciplinável, que devem ser tratados e estudados pela medicina mental. O crime, como anormalidade que é, também fica patologizado, e por isso deve ser tratado pela psiquiatria:

E sentindo que os crimes säo, na maioria das vezes, a expressäo de anormalidades mentais transitórias ou permanentes, que merecem ser estudadas em todos os intimos aspectos de sua determinaçäo, pediu ao Governo e conseguiu a crią̧āo do primeiro Manicômio Judiciário, fundado na América do Sul, onde são observados os psicopatas criminosos e onde são eles assistidos, como doentes, em enfermarias brancas e não em cárceres escuros. (Professor Juliano Moreira, 1931:3)

A prática psiquiátrica se exercerá sobre todas as instâncias de onde possa emergir a doença mental, não mais limitando sua ação ao asilo, mas tornando-a cada vez mais abrangente e mais específica, isto é, abrangendo um espaço social cada vez mais amplo, e, ao mesmo tempo, constituindo sobre esse espaço um saber, tanto teórico quanto prático, cada vez mais especificado, de acordo com cada uma de suas instâncias.

Assim, os 'verdadeiros doentes' serão separados dos senis, dos epiléticos, dos alcoólatras, dos alienados criminosos, gerando um certo número de iniciativas práticas, como o projeto de criação de colônias agrícolas especiais para o atendimento a esses desviantes, a criação do Manicômio Judiciário, a penetração explícita da psiquiatria na Justiça e a aprovação de uma lei federal de assistência. 
Como afirma Castel (1976), essa separação estabelece uma dualidade medicina e assistência - que se prolonga em heterogeneidade institucional: serviços especializados de um lado, e estabelecimentos de 'recuperação preventiva' ${ }^{64}$ de outro. Segundo Castel, isso apresenta um inconveniente para uma estratégia de expansão de medicina mental, a dificuldade de tratar todas as populaçōes levando a que se abandonem as que não podem ser tratadas por um esquema médico mais exigente a outras instâncias. Para resolver essa dificuldade, existe a opção de quebrar a relação privilegiada da prática psiquiátrica com o espaço hospitalar. Nesse caso não se trata de medicalizar o asilo, mas de intervir nas 'superfícies de emergência' da loucura, nas instituições não médicas - a escola, as Forças Armadas, a família -, à guisa de prevenção e profilaxia. Trata-se menos de agir sobre o indivíduo que de modificar o meio com programas de higiene, que terminam por situar a psiquiatria como uma tentativa malsucedida de estabelecer uma unidade entre a tecnologia asilar, o código nosográfico, mal distinguido de uma fenomenologia social da desordem e de um novo projeto de assistência. Tal tentativa entretanto não resulta numa síntese; ao contrário, acaba por caracterizar a medicina mental como um sistema de dois pólos: trabalho sobre as populaçōes tratadas nos hospitais e atividades de prevenção com fraco suporte institucional.

No Brasil, a psiquiatria teve que encontrar um modelo amplo o suficiente para abranger esses dois pólos. O modelo de Kraepelin foi bastante marcante nas investidas práticas de nossos psiquiatras, que deveriam, para alcançar seu objetivo de psiquiatrização e medicalização da sociedade, medicalizar não somente o hospício propriamente dito, reformando-o inteiramente, como também a sociedade inteira, apresentando medidas práticas totalmente novas. Conforme Castel (1976), tais medidas envolveriam a criação de uma nova ideologia, de atuação sobre a família, as Forças Armadas e a Justiça por meio de projetos de institucionalização de estabelecimentos especiais para outros tipos de desviantes além do louco, da estatização do hospício, da promulgação de uma lei nacional de assistência e do posicionamento da psiquiatria como um discurso de 'tutelarização'.

Como afirma Castel (1976), a transformação do fundamento teórico da doença mental vai produzir um duplo efeito. Por um lado, os prognósticos pessimistas comandados por uma etiologia orgânica, o aumento do

${ }^{64}$ Traduzo por 'recuperação preventiva' a idéia de estabelecimentos de gardiennage mencionados por Robert Castel em L 'Ordre Psychiatrique: l'âge d'or de l'aliénisme (1976). 
número de incuráveis, o aparecimento dos 'ineducáveis' vão denegrir a função do asilo. Por outro lado, um campo indefinido de intervençōes se abre: prevenção, profilaxia, através das quais o médico oferece serviços em toda parte onde aparece risco de desordem. A essas novas atividades, que Morel chama de tratamento moral - designação com forte conotação clássica -, Castel atribui o caráter de estratégia de tutelarização.

Os psiquiatras atribuem-se então a função de aconselhar e inspirar aqueles que decidem na ação política voltada para a população, oferecendo seus serviços em toda parte onde houver risco de desordem; oferecendo-se, em suma, para incutir, a exemplo de Kraepelin, uma nova mentalidade na população.

Educar a população para uma eficaz cooperação em prover esses sanatórios; tornando de tal modo mais popular o conceito da natureza da doença mental e pedindo à opinião pública bem instrutda a seguir e a abrir caminho para sucessivos melhoramentos. (Kraepelin, 1856-1926:introdução)

A nova mentalidade será tanto mais útil quanto se esclareça, por meio de um discurso psiquiátrico, o conceito medicalizado da alienação. Desse modo, os psiquiatras poderão contar com o auxílio da opinião pública para a implantação de um sistema assistencial preventivo e terapêutico. $O$ objetivo de psiquiatrizar a opiniáo pública torna-se uma meta fundamental para a psiquiatria, na medida em que constitui em entrave à realização das medidas de prevenção e de cura da alienação mental propostas pelos psiquiatras, pois, na verdade, a exigência de tais medidas não surge do povo; ao contrário, ela se coloca no seio da medicina mental que a traz às populaçōes:

O problema é sempre visto de modo unilateral. Para os agentes da autoridade como em geral para o público, ele se cifra nas medidas de reclusāo destinadas a doentes perigosose incômodos. Para as nossas instituiçōes de caridade, como para a grande maioria dos médicos, os loucos são inválidos psíquicos a que se devem aplicar as mesmas providências de abrigo e proteção que se destinam aos afetados da invalidez fisica e esse dever de humanidade se supóe esgotado quando se aparelhou para eles, sob o nome tradicional de asilo ou hospicio, um refúgio em que se reduz a quase nada a missāo de hospital. (Rodrigues, 1906:300)

A argumentação da psiquiatria em favor dessas medidas é explicitada por Kraepelin na sua proposta de criação de manicômios para alcoólatras, em que ele mostra a necessidade de cuidados médicos para estes anormais. ${ }^{65}$

${ }^{65}$ Kraepelin afirma, em seu Tratado de Psiquiatria (1856-1926), que a construção do sanatório para alcoólatras sob o cuidado do médico tornará compreensível gradualmente ao povo, de maneira sempre mais evidente, como a intoxicação crônica é uma doença que deve ser combatida com a ajuda do médico. 
Mas não é só para os doentes perigosos que se afirma a importância da intervençāo médica: também nos casos de enfermidades que não representam perigo nem incômodo para a sociedade, dos 'conscientes e orientados', deve-se criar um tipo especial de assistência, pois estes não podem ser tratados em manicômios comuns. ${ }^{66}$

A psiquiatria oferecerá tratamento não só aos que representam risco de desordem social, mas a todos aqueles que, mesmo 'conscientes e orientados', são improdutivos devido a problemas psíquicos.

${ }^{66}$ Trata-se de uma proposta, como a de Kraepelin, de criação de sanatórios para aqueles doentes nervosos privados de condiçōes, que não podem ser submetidos à cura no manicômio, mas que, ao contrário, podem ser danificados em decorrência de uma permanência em instituiçōes do gênero. A esse tipo pertencem todos os enfermos conscientes. 


\section{3}

\section{A Prática Psquítrica como Cura da Anormalidade}

O que era hospital psiquiátrico tornou-se um grande parque $m u$ nicipal no qual as velhas estruturas foram esvaziadas ou destinadas a outros objetivos. Existem: vinte apartamentos para ex-internado, uma unidade de reabilitação para deficientes muito graves e uma unidade do centro de sauide mental da regiäo. Existem ainda: uma escola maternal, uma escola primária e laboratórios da universidade; existe sobretudo uma série de estruturas destinadas às atividades dos centros e das cooperativas: um bar; um laboratório de teatro, um laboratório artístico de muisica, pintura, de vídeo, uma sala de ginástica, uma sala de estética etc. $O$ dado mais significativo de todas estas atividades, e em particular dos laboratórios, é o fato de que são utilizadas conjuntamente por 'normais', por pacientes psiquiátricos, por tóxico-dependentes (e sobretudo por jovens).

Rotelli, Desinstitucionalizaçāo

Ao momento de ruptura do saber psiquiátrico, que delimita pela primeira vez o que poderíamos chamar de uma corrente psiquiátrica no Brasil, corresponde uma ruptura na prática asilar, também marcada pela obra de Juliano Moreira, claramente influenciada pelo modelo alemão de Kraepelin. Esse momento, final do século XIX, dá à psiquiatria uma nova configuração, tanto no âmbito do saber quanto no da prática, permitindo-nos diferenciá-la claramente da prática psiquiátrica precedente. Ele se faz perceber na elaboração de um novo corpo teórico e nas transformaçōes instituídas por um novo sistema de assistência ao alienado. 
A principal característica do novo sistema de assistência é não mais se restringir ao espaço asilar, centro fundamental da psiquiatria até a época de Teixeira Brandão, mas estendê-la a outras instâncias da sociedade - escola, família, Forças Armadas - agora compreendidas como diretamente relacionadas ao problema da alienação mental.

Também por outros objetivos, a terapia psiquiatrica se estende além dos limites dos manicômios propriamente ditos. Existem grupos de enfermos que têm a necessidade do tratamento do alienista sem que devam porém ser enclausurados nos manicômios. (Rodrigues, 1906:300)

No concernente à prática, a psiquiatria do final do século XIX e do início do século XX ultrapassa seus próprios limites, o doente mental e o hospício, para originar novas formas assistenciais, criadas especialmente para o novo tipo de indivíduo a quem começa a se dirigir: o desviante moral em geral, não necessariamente atingido pela doença mental, mas doente mental em potencial.

A questão que se pode colocar é até que ponto as novas modalidades da prática psiquiátrica do século $\mathrm{XX}$ significam uma ruptura com as práticas psiquiátricas precedentes ou constituem apenas uma reformulação do sistema de assistência ao alienado instituído no século XIX, ao longo do qual foi-se aperfeiçoando. $\mathrm{O}$ importante, nesse caso, é analisar as mudanças do sistema assistencial que estabelece uma relação de interioridade não só com o doente mental, mas agora também com o Estado, a família, a Justiça, a legislação, a escola e outras indivíduos - os anormais -, originando as instituiçôes asilares que hoje conhecemos.

Com Juliano Moreira, ocorre um deslocamento do campo de açăo da psiquiatria de uma única modalidade asilar - o hospício -, ponto fundamental da prática psiquiátrica do século XIX, para diversas formas asilares, como a colônia agrícola e o manicômio judiciário, e mesmo não asilares, como a assistência heterofamiliar. São unidades criadas para assistir a um novo tipo de população que agora aparece também como objeto da medicina mental: a população dos desviantes, alcoólatras, sifilíticos, epiléticos, delinqüentes. Trata-se de estabelecer para esses grupos instituiçóes especiais, adaptadas às suas necessidades.

A psiquiatria amplia seu objeto, estabelecendo desde logo uma separação fundamental entre os degenerados e os 'verdadeiros' doentes mentais, e propõe para cada caso um tipo especial de assistência. Ao mesmo tempo 
que exige maior medicalização, no sentido da patologia clínica, para os 'verdadeiros' doentes mentais, sugere um tratamento especial de reeducação para os degenerados. Estes, uma vez diferenciados, devem ser agrupados em asilos especiais, onde possam ser recuperados para a vida em sociedade e para o trabalho, ao invés de ficarem sem nenhuma assistência, o que permite que conseqüências mais graves os tornem irrecuperáveis e perigosos.

O novo sistema assistencial é, portanto, criado com o objetivo explícito de debelar todas as anomalias mentais, por maiores que sejam os limites dessa tarefa, tornando-se cada vez mais abrangente, ou seja, tomando a si o encargo de penetrar cada vez mais na vida de todos os indivíduos que de alguma forma estejam inseridos no contexto da psiquiatria. Esse alargamento dos limites da psiquiatria tem como condição necessária a concepção médica da anormalidade, que surge no final do século XIX para designar os indivíduos que, como os loucos e ao contrário dos normais, não são disciplináveis mas não podem ser incluídos na categoria dos doentes mentais propriamente ditos.

No modelo de Kraepelin, em que se baseia o novo sistema brasileiro da assistência ao alienado, a psiquiatria dirige sua ação em dois sentidos. Primeiramente, na direção dos indivíduos a quem os psiquiatras devem assistir, por meio de novas técnicas terapêuticas e preventivas, não se limitando mais ao alienado mental, mas abrangendo todo louco em potencial; sua ação se dirige, neste caso, ao desviante moral de todo tipo - o alcoólatra, o epilético, o sifilítico, o criminoso - e ao indivíduo normal, ainda criança, que por uma educação defeituosa, acrescida à predisposição hereditária, pode-se tornar, em um dado momento, doente mental. Em segundo lugar, na direção das instituiçōes sociais como a escola, a família, o Estado, os dispositivos legais, psiquiatrizando-os para transformá-los em auxiliares nessa ação de terapia e prevenção contra a loucura, que caracteriza a prática psiquiátrica no século $\mathrm{XX}$.

$\mathrm{O}$ argumento dos psiquiatras é que a psiquiatria é de grande valia na construção da nova sociedade, porque se baseia na ciência, no conhecimento das causas e dos focos de doença mental, que prejudicam os preceitos da liberdade individual e do desenvolvimento econômico, social e político, então reconhecidos como imprescindíveis ao progresso da nação. É por meio de críticas aos governos federal e estaduais quanto à insuficiência e ineficácia da assistência ao alienado que essa argumentaçáo se reforça. 
Em 'Legislação sobre assistência a alienados', nos Arquivos Brasileiros de Psiquiatria, Neurologia e Ciências Afins, Nina Rodrigues comenta:

Tudo o que se tem feito até aqui, pelo governo central como pelos governos locais, possui um caráter fragmentário, de soluçāo incompleta, de medidas de ocasiāo, obra feita sem $o$ conhecimento preciso de todos os elementos do problema a resolver, sem atenção ao necessário consórcio das luzes fornecidas pela ciência com as exigências ao meio social, econômico e político, a que a instituição se destina. (Rodrigues, 1906:299-300)

O novo sistema implica, portanto, uma intervenção da psiquiatria nos asilos e fora deles, e se apresenta como fundado no conhecimento científico, em nome do que institui colônias agrícolas para epiléticos e alcoólatras, manicômio judiciário para o criminoso louco, assistência familiar para os alienados que já estão em fase de reintegração na sociedade; reforma o hospício, fazendo-o parecer-se com um hospital comum onde se desenvolvem a pesquisa e a tecnologia - laboratórios, serviço cirúrgico etc. -; interfere na escola e na família ditando normas medicalizadas de educação; auxilia na seleção dos imigrantes, na seleção dos soldados, para melhor assegurar a disciplina das Forças Armadas; e critica a legislação, exigindo que o termo da lei seja bem elaborado o suficiente não só para proteger a sociedade do perigo que o louco representa, mas também para assegurar o direito de liberdade individual do louco contra o qual o enclausuramento se impóe: "O caráter de exceção que cria, para este caso especial da assistência pública a necessidade de proteção legal toda particular reclamada pelo estado de incapacidade civil e pelas imposiçōes de uma restrição à liberdade individual dos insanos dementes" (Rodrigues, 1906:300).

Daí a ênfase dada, nessa fase, aos problemas relativos à terapêutica e à investigaçáo da organização e do funcionamento das diversas formas asilares e mesmo não asilares, dentro dos limites científicos que o saber psiquiátrico oferece. A cura científica passa a ser um objetivo fundamental da assistência ao alienado no Brasil.

A concepção da cura como recuperação da normalidade vai assinalar a ruptura entre a prática psiquiátrica do século XX e a do século XIX. Juliano Moreira refere-se a essa descontinuidade como uma passagem da assistência ao alienado no Brasil de uma fase de cuidados detentores para a fase dos cuidados curativos, esta última radicalmente diferente do período precedente que durou, em sua opinião até 1900, quando o louco deixa de ser apenas isolado, sem a menor possibilidade de cura, para receber um tratamento racional (Moreira, 1905a). 
O chamado "tratamento racional" corresponde a uma prática médica que utiliza, além de medicamentos e técnicas do tipo da clinoterapia e da punção lombar, dados estatísticos, registros e uma nova disciplina (Moreira, 1919). A utilização desses recursos denota o envolvimento da medicina mental com o projeto da medicina social, ${ }^{67}$ cuja prática pretende penetrar em toda a sociedade, projeto desenvolvido desde o século XIX com base na compreensão de que o perigo urbano exige a criação de uma tecnologia de poder capaz de controlar os indivíduos, tornando-os produtivos e inofensivos.

A distinção entre duas fases bem delimitadas de assistência corresponde, na realidade, mais a uma mudança no conceito de cura do que ao fim de uma fase em que a cura não seria objeto de preocupação, conforme fazem parecer os psiquiatras no início do século. Ao abordar os cuidados curativos, Juliano Moreira refere-se a uma fase em que a cura é medicalizada, isto é, determinada pela prática médica, lançando mão dos recursos da medicina - medicamentos especiais, repousos etc. - à qual podemos opor a fase anterior, em que o tratamento psiquiátrico era prescindido.

É certo que os documentos médicos atestam uma maioria esmagadora de incuráveis no hospício, e que a presença do médico era dispensável. A idéia de cura, porém, já está presente na criação mesma do hospício, que por princípio só deveria receber os loucos curáveis. Pelo menos na justificativa para a construção de um asilo especial para alienados, a cura constituía-se como seu objetivo fundamental.

Em Danaçāo da Norma (Machado, 1978), as críticas ao mau funcionamento da instituição administrada pela Santa Casa da Misericórdia dirigem-se, entre outros, ao problema da população mista de loucos curáveis e incuráveis. A criação do hospício obedece à exigência de só receber loucos e curáveis; de não receber os idiotas, imbecis, epiléticos ou paralíticos dementes, que são incuráveis e podem conviver com a família. Essa seria a população ideal. Retirando-se o caráter de lugar específico para loucos curáveis, o hospício transforma-se numa instituição de caridade útil à sociedade.

\footnotetext{
${ }^{67}$ No século XIX, "a teoria elaborada pela medicina social com o objetivo de diagnosticar e combater a periculosidade, que começa a ser percebida como habitando necessariamente a cidade, tem como alvo da reflexāo uma desordem heterogênea e complementar heterogênea, na medida em que apresenta uma variedade de aspectos; complementar, pois a cidade é tematizada como uma totalidade articulada, produto da inter-relaçāo de diferentes realidades ou características. A reflexão médica sobre a cidade é ao mesmo tempo analítica e sintética. Esquadrinha e totaliza" (MACHADO et al., 1978:261).
} 
O fato de o asilo ter sido criado para prover a sociedade de um espaço terapêutico para alienados e ter sido entregue não aos médicos, mas às freiras da Santa Casa, que já estavam acostumadas a recebê-los em suas enfermarias, pode ser compreendido como decorrência de uma concepçáo não médica de cura, mais ligada à educação do que à medicina, baseada numa percepção do louco como doente na medida em que não se submete aos padróes morais que indicam a normalidade social. Portanto, as freiras, com seus princípios religiosos e filantrópicos, louváveis pela moral da época, poderiam ser, e foram, consideradas capazes de cumprir a função de assistir aos doentes mentais, não pelos psiquiatras, é claro, mas pelo Estado e pela opinião pública, relutantes em reconhecer o poder terapêutico da medicina mental.

É do ponto de vista da medicalização da cura que a fase iniciada em 1900 foi considerada pelos psiquiatras como positiva, isto é, curativa, diferente daquela considerada 'detentora', de açāo puramente negativa, ou seja, que priva o indivíduo de sua liberdade sem que tal restrição tenha uma desculpa plausível, que seria a terapia. A idéia que cauciona essa distinção é a noção de que somente são positivos os cuidados médicos. $\mathrm{Na}$ opinião de psiquiatras, a cura não se exerce até 1900 , por falta de uma organização apropriada do hospício, ou seja, de uma organização médica. A descoberta da organização do hospício como inadequada, no começo do século XX, além de atestar sua degradação, seu mau funcionamento, significa fundamentalmente uma nova concepção de doença mental, novas categorias nosográficas, novos métodos terapêuticos.

As críticas dos psiquiatras eram, contudo, mais uma luta pelo poder da psiquiatria sobre o louco, manifesta na denúncia da situação do hospício que, longe de alcançar sua meta, funcionava como mais uma unidade asilar onde os loucos eram depositados. Essas críticas procuravam mostrar a necessidade da medicalização do espaço asilar, retomando-o na sua função de curar o louco, para que os hospícios pudessem corresponder aos preceitos teóricos da psiquiatria. Eram feitas em função das falhas de um poder administrativo leigo, que entravava o tratamento e considerava a presença do médico prescindível e seu poder, reduzido e insuficiente para que os hospícios pudessem corresponder aos preceitos teóricos da psiquiatria.

A chamada fase dos 'cuidados curativos' é aquela em que os psiquiatras, fortemente marcados pela preocupação de dar um respaldo científico às medidas assistenciais a serem tomadas, tentam, como Juliano Moreira, di- 
ferenciar modalidades de assistência de acordo com as diversas formas de doenças do cérebro, criando hospitais-colônias especiais para epiléticos, alcoolistas e deficientes, imbecis etc.

O saber científico, tido como fundamento da ação psiquiátrica nesse novo momento da psiquiatria, pode ser considerado mais uma justificação, uma legitimação médica do novo sistema assistencial, do que propriamente sua condição de possibilidade. $\mathrm{Na}$ realidade, as novas formas de instituição asilar não representam a importação, ou seja, a influência direta da nosografia sobre a prática. A criação dos novos espaços terapêuticos e de medidas preventivas institui espaços que localizam e distribuem os indivíduos em seu interior, a partir de categorias muito pouco médicas como "dementes", "tranquiilos/agitados", "imundos", "crianças, homens/mulheres" (Moreira, 1905a:167), do mesmo modo como no século $\mathrm{XIX}^{68}$ havia sido estabelecida a separaçāo dos loucos no hospício, sem qualquer correspondência com a nosografia das doenças mentais.

As novas modalidades de assistência resultam da divisão dos indivíduos da sociedade entre normais e anormais, e da subdivisão dos anormais em diferentes tipos. É a medicalização dos diferentes tipos de anormais que vai determinar a nosografia e, ao mesmo tempo, um sistema assistencial diversificado, com tratamento institucionalizado, especial para cada tipo de doente.

É importante ressaltar que a prática psiquiátrica do século $\mathrm{XX}$ se baseia fundamentalmente na divisão da população em normais e anormais exatamente na época em que se incrementa no Brasil a concepção de população como força de trabalho, força produtiva. Tal força não pode ser perdida, mas deve, antes, ser normalizada, assistida, sendo os anormais considerados degenerados, que necessitam de tratamento especial para se transformarem em elementos úteis à sociedade.

Surge assim a concepção de "doenças sociais" (Moreira, 1929b:61), ou seja, doenças que representam grande risco para a manutenção da ordem social e por isso entravam o desenvolvimento da nação. São doenças táo freqüentes que passam a ser consideradas como 'endemias sociais' - alcoolismo, epilepsia, sífilis - responsáveis por grande contigente de criminalidade.

${ }^{68} \mathrm{Na}$ organização do espaço terapêutico, no século XIX, divide-se a população asilar de forma heterogênea: "A primeira divisão é sexual; a distribuição dos indivíduos ainda se refina pela divisão dos pensionistas de primeira e segunda classe em tranqüilos, limpos, agitados, imundos" (Manoel José Barbosa apud MaCHado et al., 1978:433). 
Os psiquiatras ressaltam então a importância de se criar um novo sistema de assistência psiquiátrica, mais abrangente, pois essa criminalidade decorre, na maior parte dos casos, de problemas ocasionados por doenças mentais. Por essa razão, Juliano Moreira afirma que a assistência a essas pessoas se impóe como medida profilática altamente eficaz e, por isso mesmo, digna se ser efetuada com a energia que a sociedade costuma dispensar para a própria conservação e para debelar os perigos sociais. São as 'doenças sociais', que vão definir o novo modelo de assistência ao alienado; para elas será necessário encontrar 'remédios sociais'.

Assim, a psiquiatria torna clara a necessidade de que sua açáo incida sobre o campo social, mostrando o perigo que as doenças sociais podem representar no processo crescente de degradação da subjetividade e da coletividade. Os psiquiatras exigem o poder de exercer sua função de cura dentro e fora do hospício, lutando contra o pessimismo que no final do século XIX substitui a esperança de recuperar o alienado. ${ }^{69}$

Os psiquiatras se esforçam por se mostrarem capacitados a curar, explicitando sua relação com o saber da medicina, ao preconizar técnicas médicas de tratamento ligadas às reaçōes fisiológicas da doença mental, como a clinoterapia, ${ }^{70}$ isto $e$, o repouso e a punção lombar, ${ }^{71}$ além de con-

${ }^{69}$ Em Clinoterapia, Difusão e Resultados no Tratamento das Psicoses (1901), Juliano Moreira rejeita a crença de que as doenças mentais são incuráveis e a de que todo alienado é um 'amputado do cérebro'. Ele relata o emprego da clinoterapia em vários países, alongando-se sobretudo nos trabalhos do alienista inglês, Tuke, referindo-se ao sucesso desse tipo de tratamento. No Brasil, refere-se a Franco da Rocha, que o empregou em alguns doentes, mas ainda sem resultados positivos.

${ }^{70}$ A clinoterapia é proposta com base nos seguintes princípio: "se o corpo está enfraquecido, se as funçōes enlanguescem, por isso que as permutas metabólicas fazem-se mal - o exercício não fará mais que agravar o mal. Necessitando o doente de toda sua energia nervosa para deter os progressos da decadência e da desorganização do cérebro, é no leito, em repouso, que se deve tratá-lo" (MOREIRA, 1901:322). Juliano Moreira analisa o problema do peso no decúbito horizontal e lastima que ainda não se tenha verificado, por meio de investigaçōes psicofisiológicas, se o repouso no leito é suscetível de paralisar a energia da atividade psíquica e a apercepção ativa de Wundt, isto é, a força diretriz do espírito, enfraquecida nos alienados. Esse seria um dado relevante para a discussão da suspeita, à época, de que a frequêencia da demência precoce em certos asilos deveria ser atribuída à aplicação da clinoterapia prolongada em doentes jovens.

${ }^{71}$ Juliano Moreira foi o primeiro, no Brasil, a efetuar a punçāo lombar com fins diagnósticos em casos de tabes dorsualis, demência paralítica, sífilis cerebral e meningites várias. Ver PeIXoto, 1931. 
tinuar a trabalhar pela reeducação do alienado, que agora se estende também ao alienado em potencial.

A concepçáo médica da cura da alienação estende-se, no século $\mathrm{XX}$, à cura da anormalidade pela psiquiatria. A anormalidade vista, no século XIX, apenas como oposto à norma, à ordem, é agora considerada patológica; o anormal torna-se não só inconveniente à disciplina, mas sobretudo patológico, e como tal deve ser submetido à 'tratamento racional', ou seja, científico. 


\section{4}

\section{Um Sistema Completo de Assistencia AOS INSANOS}

No início do século $\mathrm{XX}$, a prática psiquiátrica rompe com a psiquiatria do século XIX, procurando atender às necessidades de um sistema de assistência amplo o suficiente para oferecer tratamento especial a todos os tipos de anormalidade psicológica, de acordo com cada tipo de distúrbio psíquico. O sistema de assistência proposto não é mais centrado num único espaço asilar, onde o isolamento no hospício é absolutamente necessário para a cura do doente mental, mas apresenta formas terapêuticas alternativas que, somadas umas às outras, pretendem oferecer a cada indivíduo anormal, degenerado, uma assistência médica que o recupere para a vida em sociedade. Inicia-se no Brasil um novo sistema de assistência disperso em diferentes formas asilares ou não asilares, que permitem penetrar em outras instâncias da sociedade, como a famflia, o governo, as Forças Armadas, psiquiatrizando a normalidade, oferecendo um tratamento diferenciado para o louco propriamente dito e para o desviante em geral, psiquiatrizando os espaços sociais de onde possa emergir a alienaçăo mental.

O novo sistema de assistência não é mais limitado ao espaço do hospicio. Ao contrário, está aberto à criação de outras instituiçōes como colônias agrícolas, assistência familiar, as quais, acrescidas ao hospício, tornam a açăo psiquiátrica difusa, isto $e$, não mais centrada num único espaço asilar. 
A assistência ao alienado em São Paulo é um exemplo do que, no início do século XX, se considera, com base no modelo alemão, um sistema de assistência completo:

Säo Paulo ficou dotado de um sistema completo de assistência aos insanos: 1. asilo fechado de tratamento. 2. Colônias-agricolas anexas ao asilo, onde o open-door ${ }^{22}$ é parcial. Só para os que merecem. 3. Dependências agricolas ou fazendas onde o open-door é completo, epara todos os enfermos. 4. Assistencia familiar dentro do perimetro do estabelecimento, como em Nichtspringe. 5. Assistência familiar fora dos terrenos do asilo, na Vila de Juquery.

(Rocha, 1912: 113)

Franco da Rocha considera esse sistema completo e correlato de uma reforma radical do serviço de assistência aos alienados, pois "saíram de um casarão fechado, soturno, resultado da adaptação de um velho convento" para uma instalação com pavilhóes isolados, separados por grandes áreas ajardinadas, com aspecto alegre e sadio, onde penetram luz e ar em profusão. $O$ prédio central compóe-se de pavilhōes separados para cada sexo e tipo de moléstia, tendo cada pavilhão seu refeitório, jardim etc., inclusive um salāo dividido em pequenos quartos, com atmosfera comum para pernoitarem aqueles que não conseguem dormir (Rocha, 1912:113).

Essa descentralização espacial não significa, contudo, que o poder do psiquiatra também se encontre descentralizado. $\mathrm{O}$ novo sistema se abre a diferentes modalidades de assistência, para ampliar o campo de açáo da psiquiatria, visando a aumentar o poder de decisão sobre a vida dos alienados, centralizando-o cada vez mais nas máos dos psiquiatras, conforme afirma Nina Rodrigues, ao analisar, em 1906, a questão da legislação sobre a assistência a alienados. ${ }^{73}$

Estando a prática psiquiátrica aberta a diversas formas de assistência, o psiquiatra poderá atender a um número maior de alienados, generalizando sua ação a todos os anormais, ao mesmo tempo que sua ação tende a tornarse cada vez mais específica e particularizada a cada caso, estendendo-se, inclusive, ao alienado em potencial.

Garantindo que esse sistema espacialmente descentralizado não disperse o poder do psiquiatra, a prática psiquiátrica se volta não somente para

72 O regime do open-door baseia-se no princípio da máxima liberdade possível, que se opõe ao isolamento na medida em que este não pode ser eficaz na recuperação do alienado porque irrita os pacientes, ao passo que a 'ilusão de liberdade' os tranqüiliza, tornando-os mais suscetíveis de serem disciplinarizados para o trabalho, para a vida em sociedade.

73 "Por isso", afirma Nina Rodrigues, "sou partidário de uma forte centralização na organização e direção da assistência aos alienados" (RODRIGUES, 1906:308). 
a terapêutica e a prevenção, mas também para uma luta em favor da estabilidade da assistência ao alienado. Propóem-se medidas dirigidas para a criação de uma lei federal que regule essa assistência, e atribui-se ao governo a responsabilidade de oferecer à sociedade meios para que se debele esse 'problema social'. Com recursos fornecidos pelos poderes públicos para a hospitalização dos doentes mentais, a psiquiatria poderá transformar esses indivíduos perigosos em inofensivos.

Uma das medidas tomadas pelos psiquiatras com esse objetivo é a campanha pela profilaxia mental, feita com o objetivo de mostrar ao governo o cuidado que se deve ter com as doenças mentais:

Grande é a preocup af̧äo dos estadistas com a freqüência da ruberculose, do câncer, da sifilis, do impaludismo, etc. Ao lado desses males é, todavia, necessdrio näo esquecer as perturbaçöes nervosas e mentais que entre nós aumentam dia a dia. (...). Por certo aquelas doenças e outras mais muito concorrem para aumento de tais perturbaçōes. Evidente, porém, éque se faz preciso encarar com segurança outros fatores sociais, que tanto preparam os momentos de eclosão dos distúrbios mentais. (Moreira \& Austregésilo, 1923:55)

Faz parte dessa campanha a crítica aos estadistas, por cooperarem com o processo social, e aos legisladores, por elaborarem uma lei obscura e ineficaz quanto às atribuiçóes do governo no tocante à assistência aos insanos:

Mas é essa mesma legislą̧äo federal sobre insanos o documento mais eloquiente que se pode produzir do atraso das nossas idéias em matéria de assistência médico-legal de alienados. $O$ insucesso das tentativas demonstra neste particular insuficiência do preparo daqueles que a fizeram, para abrafar numa vista de conjunto toda a vasta complexibilidade do problema. (Rodrigues, 1906:301)

O governo e a lei constituem-se como importantes catalisadores da prática psiquiátrica no século $\mathrm{XX}$, porque são instâncias com poder de decisão sobre os problemas sociais, que podem intervir, em âmbito nacional, na questão da assistência ao alienado. Tal intervenção sempre se faz por meio da delegaçăo de poder a pessoas competentes - no caso, aos psiquiatras capacitados a exercê-lo, na medida em que o saber psiquiátrico seja reconhecido como um conhecimento médico e científico das causas da loucura e dos melhores meios para saná-la.

$\mathrm{O}$ início do século XX marca o surgimento de uma nova prática psiquiátrica, que abandona o sistema asilar fechado, baseado no 'princípio de isolamento' de Esquirol, para investir num sistema de assistência aberto, que se funda sobre o princípio do open-door escocês, ou seja, o princípio da máxima liberdade possível. No regime do open-door os doentes podem transitar livremente no interior do asilo e, em, certos casos, fora dele; nesse 
regime são banidos os asilos fechados, para que o doente não se sinta irritado, o que prejudica o tratamento. Em 1910, Juliano Moreira explicita sua proposta de retirar das instituiçóes de assistência tudo aquilo que lembre caserna ou prisão, pois estas irritam o doente, atrapalhando o tratamento.

O hospício é reformado, a exemplo de Kraepelin, para se transformar num hospital com a aparência de um hospital comum, sem grades, nem muros altos, nem coletes de força. São criadas as colônias agrícolas, com trabalho, visitas aos pacientes e passeios ao ar livre, para manter uma ilusáo de liberdade criada no paciente pelo open-door, que se completará com passeios aos domingos nos arredores das colônias, sobretudo com os pacientes, conforme propóe Juliano Moreira ao preconizar a criação de colônias para os epiléticos. A idéia de produzir uma ilusão de liberdade, suscitada nos pacientes por meio do open-door, demonstra o caráter sutil do exercício do poder da instituição psiquiátrica.

Institui-se o sistema de assistência heterofamiliar, na periferia do hospital-colônia, exercida por empregados da colônia ou por sua família, em casinhas construídas pelo Estado. ${ }^{74}$ Enfim, cria-se uma série de modalidades de assistência que variam de acordo com o grau de liberdade que o doente pode ter, o qual será determinado pelo grau de disciplina e de capacidade para o trabalho.

A proposta de implantação de um sistema completo de assistência aos 'anormais', incluindo projetos de criação de reformatórios, de assistência familiar, etc. - que se insere no projeto de medicalizaçáo e psiquiatrização da sociedade - corresponde, sem dúvida, àquilo que Foucault chama de uma 'anatomia política' do corpo e de uma 'biopolítica da população'.75

\footnotetext{
${ }^{74}$ Sobre a construção dessas casas como atribuição do Estado, ver MOREIRA (1910).

${ }^{75} E$ importante aqui salientar que a grande preocupação de Foucault com a questão do poder está ligada, por um lado, ao mal-estar gerado por suas formas de exercício em nossa sociedade; por outro lado, ao fato de que a maneira como o poder se exerce, numa sociedade como a nossa seria, ainda muito mal conhecida. Em sua opiniāo, as generalizaçóes marxistas, concernentes à dominação da classe burguesa, não dão conta dessa questão. Elas não explicam como o poder se exerce. Mesmo que consigam apontar os responsáveis pelas decisōes, não pesquisam como e por que elas foram tomadas, como puderam ser aceitas por todos e de que maneira ferem uma determinada categoria de pessoas. A pesquisa genealógica propõe novas chaves de interpretação, não do conceito de poder, mas de seu exercício, em sua produtividade, na qual a constituição de novos saberes exerce uma função indispensável, sejam eles científicos ou apenas com pretensão à cientificidade.
} 
A primeira é exercida por meio de tecnologias de controle e sujeiçáo dos indivíduos. Trata-se do estabelecimento de técnicas que implicam coerção ininterrupta e constante das operaçóes do corpo, garantindo a sujeição permanente de suas forças e impondo-lhe uma relaçáo de docilidade-utilidade, as disciplinas. Como Foucault afirma em Vigiar e Punir (1975), diversos procedimentos disciplinares já existiam há muito tempo nos conventos, nas Forças Armadas, nas oficinas. Mas, a partir do século XVII e XVIII, as disciplinas tornaram-se fórmulas gerais de dominação. $O$ momento histórico do surgimento das disciplinas, ressalta Foucault, é o momento em que nasce uma arte do corpo humano, que visa não apenas ao crescimento de suas habilidades, nem ao peso de sua sujeição, mas à formação de uma relação que no mesmo mecanismo o torna tanto mais obediente quanto útil, e vice-versa.

\begin{abstract}
Forma-se então uma politica das coerçóes que são um trabalho sobre o corpo, uma manipulação calculada de seus elementos, de seus gestos, de seus comportamentos. $O$ corpo bumano entra numa maquinaria de poder que o escava, desarticula e recompöe. Uma anatomopolítica que é também uma mecânica do poder está nascendo; ela define como se pode ter posse sobre o corpo dos outros, näo simplesmente para que façam aquilo que se deseja, mas para que operem como se quer, com as técnicas, segundo a rapidez e a eficácia que se determina. A disciplina fabrica, assim, corpos submetidos exercidos, corpos 'dóceis'. (Foucault, 1975:139-140)
\end{abstract}

Ao lado da anatomopolítica do corpo humano, explica Foucault, a partir de meados do século XVIII, desenvolveu-se uma forma de poder sobre a vida centrada no corpo compreendido como espécie - atravessado pela vida, suporte dos processos biológicos, como nascimento, proliferação, mortalidade, nível de saúde, duração da vida, com todas as condiçōes que pode fazê-los variar - que remeteu a uma 'biopolítica da população' constituída de intervençōes e controles reguladores.

Foucault analisa de que modo os procedimentos da repartição disciplinar correspondem a saberes e técnicas contemporâneos de classificação e de ordenação em quadros, como também de que modo introduzem o problema específico dos indivíduos e da multiplicidade. Da mesma forma, os controles disciplinares da atividade correspondem a todas as pesquisas teóricas e práticas sobre a maquinaria natural do corpo. Ao mesmo tempo, descobrem-se processos específicos ao corpo com vida, comportamentos e exigências orgânicas que vão substituir a simples física do movimento. $O$ corpo aparece como provido de condiçōes de funcionamento próprias a um organismo, que fazem com que o poder disciplinar se dirija a uma individualidade analítica, celular, natural e orgânica, a partir dos corpos que controla. 
Por meio das disciplinas, surge o poder da norma. Na sociedade moderna, o normal se estabelece como princípio de coerção não só no ensino, na regularização dos procedimentos e dos produtos industriais, mas na organização de um corpo médico e um enquadramento hospitalar da nação suscetíveis de fazer funcionarem normas gerais de saúde. Do mesmo modo que a vigilância, a normalização torna-se um dos grandes instrumentos de $\operatorname{poder}^{76}$ a partir do final da época clássica. Ela substitui ou acrescenta graus de normalidade, que são signos de pertença a um corpo social homogêneo, mas que se divide por meio de uma distribuição das classes.

Num certo sentido, explica Foucault, o poder de normalização constrange, com o objetivo de homogeneizar as multiplicidades, ao mesmo tempo que individualiza, por permitir as distâncias entre os indivíduos, determinar níveis, fixar especialidades e tornar úteis as diferenças.

A partir do século XVIII, quando o poder sobre a vida centrou-se no corpo como espécie, todos esses processos operam para garantir, sustentar, multiplicar a vida e ordená-la. É quando surgem os problemas de natalidade, longevidade, saúde pública, habitação, migração, que exigem técnicas diversas para obtenção da sujeição dos corpos e o controle das populaçōes. "Abre-se, assim, a era do "bio-poder" (Foucault, 1977b:132).

A noção de população como algo que representa um problema econômico e político e, ao mesmo tempo, riqueza, mão-de-obra ou capacidade de trabalho, em equilíbrio, aparece quando os governos percebem que não têm que lidar apenas com sujeitos ou povos, mas com um conjunto de variáveis específicas da populaçáo - saúde, doença, habitação, trabalho etc. Essas variáveis situam-se, de acordo com Foucault, no ponto de interseção entre os movimentos próprios à vida e os efeitos de poder particulares das instituiçóes.

As disciplinas do corpo e as regulações da populaçăo constituem dois pólos em torno dos quais se organizou o poder sobre a vida, que é considerado por Foucault como uma grande tecnologia de poder de duas faces - a

${ }^{76}$ É importante observar que Foucault define o poder - rede de micropoderes - pelos mecanismos de resistência, pelo seu caráter estritamente relacional em termos de correlaçōes de forças, que só existem em função de uma multiplicidade de pontos de resistência que representam, nas relaçōes de poder, o papel de adversário, ou de apoio, ou de alvo. Esses pontos perpassam toda a rede de poder: "lá, onde há resistência e, no entanto (ou melhor, por isso mesmo), esta [a resistência] nunca se encontra em posição de exterioridade em relação ao poder" (FouCAULT, 1977b:91). 
anatômica e a biológica. Trata-se da administração dos corpos, gestão calculista da vida, por meio de técnicas e de diversas disciplinas, de práticas políticas e observaçóes econômicas dos problemas da população.

As duas direçóes ainda aparecem de forma bem separada no século XVIII, afirma Foucault em História da Sexualidade I (1977b). A partir do século XIX, o poder transforma-se em agenciamentos concretos - o dispositivo da sexualidade será um deles, e, sem dúvida, o da normalidade, outro - que constituirão a grande tecnologia de poder no século XIX, capaz de majorar as forças, a vida em geral, através da inserção controlada dos corpos no aparelho de produção e por meio de um ajustamento dos fenômenos da população aos processos econômicos.

Os rudimentos da anátomo e biopolítica, inventados no século XVIII, utilizados por instituiçōes bem diversas (a família, a escola, o exército, a polícia, a medicina individual ou a administração das coletividades), agiram no nível dos processos econômicos e das forças da vida, com métodos de poder capazes de majorar a vida em geral, e de técnicas presentes em todos os níveis do corpo social, utilizadas pelas instituições.

A possibilidade de encarregar-se da vida e de seus mecanismos, fazendo com que a espécie entre em jogo em suas próprias estratégias políticas, no domínio dos cálculos e da transformação da vida humana, é o que Foucault (1977b:134) considera o "limiar de modernidade biológica" de uma sociedade. Esse limiar é coetâneo do aparecimento, na modernidade, do homem em sua especificidade de ser vivo, com um corpo concreto, sujeito e objeto de si mesmo, com uma historicidade própria. Foucault ressalta, nesse limiar, a importância da proliferação das tecnologias políticas investindo sobre todo o espaço da existência.

O que caracteriza o bio-poder é a crescente importância da norma que distribui os vivos num campo de valor e utilidade. Tal pode tem a função de qualificar, medir, avaliar, hierarquizar, operando distribuiçóes em torno da norma. A própria lei funciona como norma, com funçōes reguladoras. Uma sociedade normalizadora é o efeito histórico de uma tecnologia de poder centrada na vida.

A principal característica das tecnologias de normalização consiste no fato de integrarem a criaçáo, a classificação e o controle sistemático das anormalidades no corpo social. Dreyfus e Rabinow (1995) assinalam que 
Foucault chamou a atenção para o fato de que o bio-poder é contemporâneo do aparecimento e da proliferaçáo das categorias de anormalidade - 0 delinqüente, o perverso etc. - que as tecnologias de poder $e$ os saberes investidos nessas tecnologias supostamente eliminariam. A expansão da normalização funciona através de anormalidades que deve tratar. Ao tentar identificar cientificamente as anormalidades, as tecnologias do bio-poder estão numa posição perfeita para supervisioná-las e administrá-las.

Em Vigiar e Punir e em Historia da Sexualidade I, Foucault aponta năo só o modo peculiar de funcionamento das normas modernas, como também o mal-estar causado por seus procedimentos. Dentre as técnicas, práticas, saberes e discursos por ele analisados, a normalizaçăo é a questão mais importante, visto que todas as sociedades têm normas e socializam seus membros de acordo com elas. O problema é que, em nossa sociedade, as normas sáo especificamente perigosas, pois funcionam de modo sutil, como estratégias sem estrategista, impondo uma rede uniforme de normalidade.

\section{O HospfCio}

A reforma do Hospício de Pedro II, em 1903, baseia-se nos novos princípios da psiquiatria do século $\mathrm{XX}$, quando a terapia não está mais relacionada ao 'princípio do isolamento', mas ao open-door, ao princípio da máxima liberdade possível, cujo principal objetivo é proporcionar ao doente uma 'ilusão de liberdade' que o tranqüilize, deixando-o mais calmo, menos rebelde e, conseqüentemente, mais receptivo ao tratamento. Os psiquiatras pretendem transformar "doentes excitáveis em trabalhadores tranqüilos" (Moreira, 1908a:172). Para atingir essa meta, as principais providências tomadas foram a retirada das grades, a negação das camisas-de-força e o fim das células de isolamento:

\footnotetext{
Encafuando um alienado em uma célula de isolamento, diz Prof. Kraepelin, ficamos garantidos contra suas mds inclinaçōes mas näo sabemos o que é feito dele. Ouvimo-lo gritar, podemos espid-lo pelo monóculo da célula, mas é inconteste que isto não é terapêutica. (...) Näo ignorais que a experiência dos mais notdveis psiquiatras demonstrou que a casa forte é o melhor meio de cultura para o desasseio, as tendências destruidas, etc. dos alienados. (Moreira, 1908a:172)
}

A eliminação de tais medidas de força não significa, contudo, uma diminuição da repressão do alienado no hospício. Ela representa apenas uma maneira de torná-la mais científica, e de exercê-la de forma muito mais 
sutil, sob a forma de 'clinoterapia', ou seja, do repouso no leito e nos banhos hidrelétricos de temperatura controlada, que constituem um calmante para subjugar qualquer rebeldia, manifesta - dos agitados - ou possível daqueles que estão em observação).

Juliano Moreira cita o exemplo da Clínica de Munique ${ }^{77}$ sob a direção de Kraepelin, onde todos os casos novos e todos os agitados sáo submetidos ao tratamento da clinoterapia: "Daí foi que resultou o grande movimento em favor da clinoterapia. Na Clínica de Munique, era escusado repetir, [para] todos os casos novos e todos os [casos de] agitados [o tratamento é] o repouso no leito" (Moreira, 1908a:172).

A clinoterapia é um tratamento que pressupōe a vigilância permanente do doente; o doente estará constantemente submetido ao olhar disciplinar de instituição asilar, ao ficar em repouso nas salas de observação, onde se encontra a maioria dos alienados: "Na Clínica de Munique, as três quartas partes dos doentes estão nas salas de observação contínua. Essa realmente se exerce, como seu nome indica, dia e noire" (Moreira, 1908a:173).

Também no banho, está o doente sob vigilância permanente; o banho, onde pode dormir e comer, é uma nova técnica do século XX para tornar o indivíduo dócil. Apesar de considerado por alguns psiquiatras da época como uma variante de coação, constitui um importante fator de cura:

Ouvir freqüentemente na França e na Itdlia denominar o uso do banho prolongado (o doente podia dormir e comer no banho) uma variante de coaçäo. Ora, entre uma camisola

\footnotetext{
${ }^{7}$ Em 'Assistência a alienados na Alemanha, Clínica de Munique' (1908a), Juliano Moreira faz um histórico, comparando "o tétrico período da Idade Média” - durante o qual não se falava nem em assistência efetiva, nem em tratamento a alienados - à fase moderna de assistência. Ele assinala os exorcismos, as torturas, as chamas das fogueiras da Inquisição, durante a Idade Média, na Europa, considerando esta, uma "fase aguda das epidemias de demoniopathia, de demoniolatria, de vampirismo", tendo as Américas escapado a "estas hecatombes sinistras". Segundo seu histórico, parece provado que em 1305, em Upsala, na Suécia, foi fundado o mais antigo manicômio da Europa, sob o nome de Casa do Santo Espírito, numa tentativa isolada. Em Bérgamo, em 1325, e em Florença, em 1387, teria havido asilos especiais para os loucos. Juliano Moreira lembra que esse progresso europeu deve-se à observação feita em países mouriscos, pelos irmãos da ordem das Mercês, de instituiçōes hospitalares especialmente destinadas aos loucos. Foi a partir dessas observaçōes que se criaram os asilos de Valência em 1409, de Zaragoza em 1425, de Sevilha em 1436, de Valladolid, Toledo e Granada. Ele ressalta a afirmação de Constans, Luvier e Dumesnil de que é diff́cil explicar por que o cristianismo, que a partir dos séculos IV e V fundara tantos estabelecimentos de caridade, esquecera por tanto tempo os alienados, tomando, somente mais tarde, do islamismo a idéia de socorrer os loucos (MOREIRA, 1908a:172).
} 
de força que constrange e é considerada meio de punição pelo doente, sem melhorá-lo em nada e um banho prolongado, ${ }^{78}$ um deleite e um meio curativo de eficácia comprovada, näo há comparaçäo possivel. (Moreira, 1908a:172)

A diferença entre os métodos coercitivos do hospício no século XIX grades, camisas de força - e os do século XX consiste no fato de os primeiros se caracterizarem pela punição e não terem em si fins terapêuticos, enquanto que o pouso no leito e os banhos, substituindo a violência pelo 'deleite', propõe-se como um meio curativo e eficaz. Essa eficácia é medida pelo nível de sujeição à força da disciplina que a terapia psiquiátrica impōe.

A clinoterapia é uma das técnicas médicas de tratamento mais restritivas da liberdade do doente em termos de espaço. Quando ela é indicada, o doente deve permanecer no leito, mesmo contra sua vontade, devendo ser forçado com o uso de medicamentos, ou até manualmente, pelos enfermeiros. "A permanência do doente no leito, quando difícil, deve ser obrigada até manualmente, por enfermeiros cuidadosos. Inicialmente, o uso de hipnóticos ajuda até que o paciente se habitue ao leito. Finalmente a simples presença do enfermeiro faz o paciente ficar no leito" (Moreira, 1901:322).

\footnotetext{
${ }^{78}$ A relaçăo entre a água e a loucura é muito antiga. Ela é apontada por Foucault no primeiro capítulo da História da Loucura (1972), Stultifera Navis, em que ele faz uma arqueologia da percepção da loucura e mostra a simbologia da água (dos rios através dos quais navegavam os loucos no Renascimento), como fator de exclusão social, purificação e reintegração espiritual, segregação. Ele afirma: "a água acrescenta a massa obscura de seus próprios valores; ela leva, mas faz mais, ela purifica; ademais, a navegação libera o homem à incerteza de seu destino" (FoucaulT, 1972:22). Mais uma vez, em Nascimento da Clínica (1977), essa relação aparece, agora na perspectiva de uma arqueologia do olhar. Foucault cita um texto do Traité des Affections Vaponeuses des Deux Sexes (POMME, 1769:60-65), para mostrar uma ruptura entre o olhar médico do século XVIII e o do XIX "Em meados do século XVIII, Pomme tratou e curou uma histérica fazendo-a tomar "banhos de 10 a 12 horas por dia, durante dez meses'. Ao término desta cura contra o ressecamento do sistema nervoso e o calor que o conservava, Pomme viu 'porçôes membranosas semelhantes a pedaços de pergaminho molhado (...) se desprenderem com pequenas dores e diariamente saírem na urina, o ureter do lado direito se despojar por sua vez e sair por inteiro pela mesma via'. O mesmo ocorreu 'com os intestinos que, em outro momento, se despojaram de sua túnica interna, que vimos sair pelo reto. $O$ esôfago, a traquéia-artéria e a língua também se despojaram e a doente lançara vários pedaços por meio de vômito ou de expectoraçāo'. E eis como, menos de 100 anos depois, um médico percebe uma lesão anatômica do encéfalo e seus invólucros; trata-se das 'falsas membranas' (BAYL, 1825:23-25) que freqüentemente se encontram nos individuos atingidos por meningite crônica" (FouCAurT, 1977:VII). O que Foucault ressalta nesse texto é a diferença "entre o texto de Pomme, que conduzia os velhos mitos da patologia nervosa à sua última forma, e o de Bayle, que descrevia, para uma época que ainda é a nossa, as lesōes encefálicas da paralisia geral, é ínfima e total. Total para nós, na medida em que cada palavra de Bayle, em sua precisāo qualitativa, guia nosso olhar por um mundo de constante visibilidade, enquanto que o texto precedente nos fala a linguagem, sem suporte perceptivo, das fantasias" (FouCAULT, 1977:VIII).
} 
A restrição física, espacial, da liberdade na clinoterapia tenta obedecer a preceitos científicos e justifica-se como científica. Dessa forma, parece tentar escapar de se constituir num modo fácil de reprimir a violência das crises. Ela reúne o saber da medicina, utilizando agentes terapêuticos como hidroterapia, ginástica sueca, massagem, eletroterapia, ao saber do arquiteto e do higienista. "Em tais construçōes deve o arquiteto, ao preparo que lhe dá o seu mister, adicionar os conselhos que lhe derem o higienista e o psiquiatra, a quem seja familiar o que se tem preconizado como melhor em outros países" (Moreira, 1901:323).

A própria arquitetura do espaço asilar para a clinoterapia será determinado pelo grau de liberdade que o doente submetido a esse tratamento pode receber, devendo permanecer sob o regime de maior ou menor vigilância. Para os doentes mais agitados, mais restriçōes, ou seja, o isolamento, construído segundo um projeto arquitetônico especial, com sala especial para os turbulentos e quartos anexos de isolamento.

Há, pelo menos, dois pontos básicos a serem considerados na formação do novo sistema de assistência: a questão máxima liberdade possível e a questão do trabalho, ou seja, da produtividade, da transformação dos alienados em 'trabalhadores tranqüilos'.

A questão da máxima liberdade possível, surgida no século $\mathrm{XX}$, está relacionada ao problema da docilidade do doente. A transformação dos doentes excitáveis em tranqüilos, e não exatamente oferecer a máxima liberdade possível, é a meta do tratamento psiquiátrico. $\mathrm{O}$ objetivo principal da terapia é fazer com que o doente seja recuperado, ou seja, disciplinado o suficiente para tornar-se tranqüilo e deixar de ser rebelde e transgressor. Como afirma Pereira (1979:25), considera-se que "A psicopatia é como um germe que tem sua origem na infância e caracteriza-se pela oposição ou transgressão sistemáticas à ordem da família, da escola, do trabalho, do exército".

Todas as formas asilares serão construídas para respeitar o regime de liberdade que deve ser graduado de acordo com o estado mental do alienado. Franco da Rocha (1912) afirma que um bom asilo deveria ter seçōes diversas nas quais a liberdade se graduasse, reconhecendo, contudo, que a preocupação de evitar aspectos de prisão, de dar ao asilo aparência de habitação comum, tem sido exagerada por parte de alguns alienistas. Pois o caráter de prisão é inevitável - se não estiver nos muros e janelas, estará no 
regime, regulamento que precisa ser um tanto severo, devido ao grande número de doentes. Para Franco da Rocha, um bom asilo deveria ter seções diversas, nas quais a liberdade fosse graduada de acordo com o estado mental do 'pensionista'.

Essa percepção da necessidade de conferir ao regulamento uma forma rigorosa, assim como de sua observância, deve-se à modalidade de exercício do poder disciplinar nas instituiçóes, como afirma Foucault em Vigiar e Punir: nascimento das prisóes (1975), ao referir-se a diferentes instituições escola, prisão, convento, Forças Armadas - sujeitas aos mesmos princípios de organização espacial e temporal. Ao fazer um estudo sobre a assistência aos alienados em São Paulo, Franco da Rocha apresenta, em Hospicio e Colônias de Juquery (1912), um histórico relevante para nossa pesquisa sobre a prática psiquiátrica no Brasil. Trata-se da adaptação de um velho convento para a instalação do Hospício de Alienados, que foi, mais tarde, em 1903 quando os alienados haviam sido transferidos para a Colônia Agrícola de Juquery - entregue ao governo do estado para servir de quartel à força pública. O mesmo velho casarão, com adaptações, é claro, serviu de sede a um convento, um hospício e um quartel. ${ }^{79}$

A divisão dos doentes, no novo hospício, em diversos tipos de asilos e no interior do espaço asilar deverá se adequar ao princípio da máxima liberdade possível, a qual será graduada pela capacidade do doente de trabalhar. O primeiro critério de distribuição dos doentes, então, baseia-se na possibilidade do trabalho, ou seja, na questão da produtividade, que os separa primeiramente em inválidos, os que não podem trabalhar, e curáveis, passíveis de serem recuperados como força produtiva, ou crônicos, sem que com isso se pretenda inserir o hospício num esquema de produtividade

${ }^{79}$ Foucault explica que a invenção das técnicas do poder disciplinar deve-se a uma multiplicidade de processos menores, de origens diferentes, localizados em diferentes espaços, que se recortam, se repetem, e se distinguem de acordo com seu domínio de aplicação, e que aos poucos formaram um método geral. Tais processos podem ser encontrados em escolas, muito cedo; foram investidos lentamente no espaço hospitalar, e reestruturaram a organização militar. Trata-se de um conjunto de técnicas minuciosas, ínfimas; sua importância deve-se ao modo de investimento político e detalhado do corpo, uma nova "microfísica do poder" (FoucauLT, 1975:140). Desde o século XVIII, essas técnicas ganham domínios cada vez maiores, tendendo a cobrir o corpo social inteiro. "Pequenas astúcias dotadas de um grande poder de difusão, disposiçôes sutis, de aparência inocente, mas profundamente suspicaz, dispositivos que obedecem a economias inconfessáveis, ou que perseguem coerçóes sem grandeza, são elas contudo que trouxeram a mutação do regime punitivo, no limiar da época contemporânea" (FouCAULT, 1975:140). 
que ofereça lucros a si mesmo ou ao resto da sociedade. A questáo da produtividade nos asilos se coloca não como uma soluçāo de problemas internos de ordem econômica, mas dentro de um contexto em que toda a populaçáo saudável e normal começa a ser compreendida como força produtiva, e a recuperação do alienado como o retorno ao normal, ao produtivo.

É necessário esclarecer a diferença entre a funçāo do trabalho na terapia psiquiátrica do século XIX e na terapia do século XX. No primeiro caso, ele é moralizador, disciplinador e tem como objetivo auxiliar a transformar o doente anti-social, perigoso, em indivíduo dócil, disciplinado. No segundo caso, o trabalho também é moralizador e disciplinador, mas ele passa a ser, acima de tudo, critério de avaliação do grau da doença mental e de sua recuperação. $O$ trabalho não é mais apenas uma técnica terapêutica, mas constitui um fator fundamental para discernir entre o indivíduo normal, socializado - que produz - e o anormal, degenerado - improdutivo.

Do ponto de vista da arquitetura, nota-se a presença destes dois critérios de divisão - princípio de liberdade e percepção do indivíduo como força produtiva - agora intrinsecamente ligados à assistência ao doente mental, determinando a construção do asilo em pavilhōes separados para os diversos tipos de doentes. Para os doentes atingidos por psicoses agudas curáveis, deve-se construir um pavilhão de tratamento com vigilância contínua, um hospital urbano, sem liberdade - porém diferente das antigas casas-fortes - com um pavilhão de observação para os recém-admitidos e sala ou pavilhão para os casos agudos, com vigilância contínua aos propensos ao suicídio. Aos alienados crônicos que podem trabalhar, deve ser oferecido trabalho nas colônias agrícolas, mas quais gozam de certa liberdade. Já os alienados inválidos devem permanecer num pavilhão chamado hospício, para serem pouco a pouco assistidos pelas famílias, com uma liberdade proporcional ao seu estado físico e mental.

Além dessas três divisões principais, o grau de liberdade permissível ao interno determinará uma nova divisão do espaço asilar em pavilhão de transição para aqueles que, não tendo necessidade de vigilância contínua, ainda não estão aptos a gozar da vida em liberdade - aí, deve haver separação entre tranqüilos e agitados; vilas para doentes sociáveis, ou seja, pequenas casas imitando casa particular; e, finalmente, pavilhōes de isolamento, para os casos de doença contagiosa, é claro, mas também para as crises muito violentas. ${ }^{80}$

${ }^{80}$ Em Clinoterapia, Difusão e Resultados no Tratamento das Psicoses (1901), Juliano Moreira propōe a clinoterapia, mas também, se for preciso, o isolamento; durante os "acessos delirantes 
$O$ isolamento a que os psiquiatras do século $X X$ se referem não deve mais ser uma célula prisão, com grades e portas trancadas. A concepção de isolamento é totalmente nova. Trata-se de uma saleta com portas abertas e com vigilância constante sobre quem a habita, ou seja, sobre os doentes muito turbulentos a quem se deve aplicar a clinoterapia.

A máxima liberdade possível é oferecida para os doentes com o mesmo fito que a constante vigilância e observação do delinqüente e o cuidadoso esquadrinhamento do espaço asilar que individualiza e fragmenta; ambos pretendem obter maior controle e produzir indivíduos úteis e dóceis. Por essa razão os indivíduos não tão dóceis nem tão disciplináveis, como os epiléticos e alcoólatras, devem ser separados.

Ao lado dessa, uma das principais razóes apresentadas para tal separação é a rejeição que, naquela época, os epiléticos sofrem por parte dos outros alienados, que têm medo do contágio das convulsōes. Essa rejeição torna os epiléticos ainda mais irritáveis e violentos, aterrorizando os outros doentes.

A idéia de um sistema completo de assistência implica, portanto, a existência, em cada estado do país, de um hospital-urbano, um ou mais hospitais-colônias não só para os alienados que podem trabalhar e gozar de um certo grau de liberdade, como também para os epiléticos e alcoólatras, que devem ser assistidos em pavilhōes anexos ao hospício, enquanto as colônias especiais não são instituídas.

\section{ASSISTENCIA AOS EPILÉTICOS: COLONIAS PARA ELES}

A proposta da criação de colônias especiais para assistência aos epiléticos, embora nunca se tenha concretizado, é um dado importante para compreendermos a prática psiquiátrica do século $\mathrm{XX}$, porque caracteriza bem a nova postura em relação aos degenerados, agora considerados 'anormais'. Os epiléticos são vistos como um grupo de degenerados, que apresentam manifestaçóes psíquicas doentias:

A concep̧ão de epilepsia passa atualmente, como a história, por um processo revisor cuja extensäo é impossivel prever. Em todo caso, sempre há de ficar um grupo de degenerados em que as reaçóes convulsivas são apenas um modo de descarga nervosa, podendo alternar com outros modos psiquicos de exteriorizą̧ão doentia. (Moreira, 1912b:315)

de natureza epiléptica, como em toda psicose aguda, é indicada a clinoterapia (...) que sendo esta [agitaçāo] violenta, é inútil insistir em manter o doente no leito. É caso para isolamento" (MoreIra, 1901:323). 
A assistência aos epiléticos denota o processo de 'patologizaçáo' dos degenerados, agora vistos como indivíduos psicologicamente anormais que passam a ser objeto da psiquiatria, a partir do final do século XIX, o que nos permite ressaltar uma diferença fundamental entre dois períodos da psiquiatria. No primeiro período, no século XIX, a assistência psiquiátrica é dirigida somente aos loucos e obedece ao 'princípio do isolamento' de Esquirol, que a restringe ao espaço asilar do hospício. No segundo, a ampliação do sistema de assistência psiquiátrico, no século $\mathrm{XX}$, é dirigida tanto para os loucos quanto para todos os indivíduos psicologicamente anormais, mesmo não alienados, dando origem a uma série de medidas práticas totalmente novas - medidas terapêuticas e preventivas que pretendem garantir a segurança da sociedade, do anormal e do poder do psiquiatra.

O projeto de assistência aos epiléticos envolve as principais questōes psiquiátricas de ordem prática surgidas a partir do final do século XIX: a necessidade, para o progresso da sociedade, de dar, como medida profilática e preventiva contra a alienação mental, assistência integral e diferenciada aos anormais; o dever do Estado de prover a sociedade desse tipo de assistência psiquiátrica, por meio da caridade pública; o tratamento médico com técnicas terapêuticas voltadas para o aspecto fisiológico da doença, e o tratamento por meio da reeducação e do trabalho, salientando o valor do trabalho ao ar livre para a higiene do doente; e, finalmente, a questão do respeito à liberdade individual do doente para efeitos de maior eficácia no tratamento.

Esse trabalho, quando bem organizado é moralizador, capaz de assegurar a disciplina ainda sem o auxilio dos meios utilizados nos estabelecimentos religiosos, como Bielefied. Como muito bem diz Marandou, é indispensável dar ao epiléptico, para mantê-lo resignado, a ilusão de liberdade. (Moreira, 1905a:167)

Juliano Moreira mostra que ao Estado compete dar assistência ao epiléticos, pois a epilepsia no Brasil é considerada como algo que contribui para a formação de criminosos no país. Deve, portanto, ser tratada como um problema social a ser evitado, devido a sua freqüência "nos exércitos, nas oficinas, nas casas de detenção, a bordo dos navios, nas ruas etc." (Moreira, 1905a:167).

Se o Estado ainda nāo está em condiçăo de fazê-lo, deve apelar para a caridade pública, e enquanto näo se criam colônias e asilos para os epilépticos näo alienados, é preciso que se anexem aos hospicios seçöes onde possam ser admitidos se quiserem se submeter a um tratamento racional. (Moreira, 1905a:168)

De acordo com Juliano Moreira, da capital deve partir o exemplo: construindo pavilhões anexos, nos terrenos do Hospício Nacional; fundando a 
colônia agrícola - terreno vasto, próprio para agricultura e horticultura, nas proximidades da cidade, não somente para torná-lo facilmente acessível, como para facilitar estudos e consultas; compondo a colônia com pavilhóes bem separados de homens e mulheres, e para os tranqüilos, os agitados, os dementes, os imundos, as crianças; construindo um hospital para as moléstias intercorrentes e para os feridos; fazendo um instituto para a educação das crianças e oficinas para adultos; instalando um laboratório para consultas.

O plano de assistência aos epiléticos é a cópia condensada do novo modelo de assistência aos doentes mentais em geral; segue o mesmo esquema da assistência social, espacialmente diferenciada para cada tipo de doença, e os mesmos preceitos terapêuticos de educação e de importância de técnicas médicas para o interior do espaço asilar. Ao distribuir os epiléticos em pavilhóes anexos ao hospício, ou na colônia agrícola, por sua vez subdividida em pavilhōes separados para homens, mulheres, imundos etc., com hospital, laboratório e instituto de educação, o projeto das colônias para os epiléticos pode ser visto como uma proposta do esquadrinhamento social que divide a anormalidade em diversos tipos, para tratá-los na especificidade que sua doença apresenta, através da instituição de múltiplas formas asilares que tornam a prática psiquiátrica cada vez mais abrangente.

\section{Os ReFormatórios PARA AlCOOLATRAS}

A idéia da criação de reformatório para alcoólatras, apesar de não ter sido realizada, é digna de nota, por mostrar a possibilidade de viabilizar, na prática, a separaçáo radical entre os 'verdadeiros doentes', a quem os hospícios são destinados, e os anormais, compreendidos, a partir do final do final século XIX, como passíveis de se submeterem à ordem social por meio de uma profilaxia específica.

O projeto de reformatórios para alcoólatras surge da concepçāo de que todo degenerado pode ser recuperado, e deve, portanto, ser assistido de acordo com as suas particularidades e não de forma indiferenciada, misturando-o aos verdadeiros doentes mentais nos manicômios, onde seriam mantidos em contato direto com os alienados ou com outros doentes, que não sofrem de perturbaçōes psíquicas, nas casas de saúde, onde não há condiçōes de oferecer-lhes um tratamento adequado. 
A assistência ao alcoolismo crônico baseia-se no modelo de assistência ao alienado, que considera a criação de sanatórios para alcoólatras como a medida de assistência extramanicomial mais urgente, a exemplo da proposta de Kraepelin, que aponta a necessidade urgente de prover sanatórios para alcoólatras, principiantes inclusive, pois qualquer tratamento falharia se nāo se instituíssem sanatórios especiais para os casos curáveis, facilitando de tal modo o princípio voluntário da cura sistemática.

\section{A necessidade mais urgente é a de prover sanatórios para alcoolatras. No que diz respeito ao alcoólatras principiantes, qualquer tratamento falharia se näo fossem instituidos sanatórios especiais para os caso curáveis, facilitando de tal modo o princípio voluntário da cura sistemática. (Kraepelin, 1856-1926,I:introdução)}

Kraepelin argumenta em favor da construção de sanatórios alcoólatras, baseando-se na concepção de assistência médica diferenciada e específica para todos os anormais. O projeto de assistência aos alcoólatras se impōe à psiquiatria como um problema social, que é o problema colocado pelos psicopatas, definidos como aqueles que "determinam direta ou indiretamente perigos, perturbaçóes e desastres da ordem social" (Noticiário, 1938:43). "A construção do sanatório para alcoólatras sob o cuidado do médico tornará compreensível gradualmente ao povo, de maneira sempre mais evidente, como a intoxicação crônica do álcool é uma doença que deve ser combatida com a ajuda do médico" (Kraepelin, 1856-1926,I:introdução).

Em seu Tratado de Psiquiatria, Kraepelin refere-se à tarefa da assistência psiquiátrica aos doentes sem recursos, que necessitam de cuidados médicos, mas não devem ser internados nos manicômios. Os reformatórios para alcoólatras são apontados pela psiquiatria, no século XX, como 'remédios sociais', reforçando o caráter social da prática psiquiátrica.

Em segundo lugar, nos encontramos diante da tarefa urgente de criar sanatórios para aqueles doentes, que não podem ser submetidos à cura do manicômio, mas que, ao contrário, podem ser danificados em decorrência de uma permanência em instituiçōes do gênero. (Kraepelin, 1856-1926,I:introdução)

Em 'Reformatórios para alcoolistas', Juliano Moreira ressalta o caráter pernicioso dos alcoolistas à sociedade, tratando-os como uma das mais daninhas endemias sociais. Em sua opiniāo, é preciso contrapor 'remédios sociais' às 'doenças sociais', como o paludismo, a tuberculose, a sífilis, o alcoolismo etc. $\mathrm{O}$ álcool contribui com a mais elevada taxa de fatores de produção dos distúrbios psíquicos. Os 'bêbedos' não são necessariamente 
alienados, apresentam distúrbios psíquicos, não recebem tratamento adequado, e deveriam ir para reformatórios.

$A$ atualidade civilizada pede ao cérebro bumano um rendimento que jamais the foi exigido. Temos pois o dever de proteger nossa boa sauide mental, fonte de energia produtora. Dat resultou a modificąâao radical na antiga concep̧̧äo social da loucura e dos distúrbios mentais. Dessa modificafão resultaram também as novas diretrizes na assistência ao psicopatas. (Moreira, 1929b:63)

\section{A ASSISTENCIA FAMILIAR}

O projeto de assistência familiar tentado em Sáo Paulo por Franco da Rocha, nas proximidades da colônia agrícola de Juquery, é mais um elemento desse momento de ruptura entre a prática psiquiátrica do século $\mathrm{XIX}$ e a do século XX. Isso porque, embora atinja um número reduzido de doentes e de famílias, ressalta o projeto de psiquiatrização nāo só do louco, como no século XIX, mas da sociedade inteira, por meio de diversos focos de intervenção da psiquiatria sobre os indivíduos.

A assistência familiar ao alienado poderia ser instituída nas casas de família próximas ao asilo, caso as pessoas que se propusessem a auxiliar nesse tipo de assistência fossem idôneas. Senão, pequenas casas poderiam ser construídas pelo governo, na periferia da colônia, e entregues aos bons enfermeiros, cujas famílias se encarregariam de cuidar dos doentes.

Uma justificativa para esse tipo de prática é dada por Juliano Moreira, lembrando a necessidade de se diminuir a cronificaçāo dos doentes, gerada pela longa permanência no asilo, e de reduzir os custos de manutenção dessas internações: "Sendo porém, crescente o perigo da superpopulaçáo nos manicômios, convindo demais em pensar nos meio de diminuir as despesas de instalaçôes de novos hospitais colônias, começaram os mentalistas a meditar nos meios de utilizar a experiência de Gheel" (Moreira, 1906b:25). ${ }^{81}$

${ }^{81}$ Desde o século VII, os loucos eram levados a Gheel, na Bélgica, em peregrinaçāo até a Igreja de Santa Dimphne, na esperança de uma cura milagrosa. Os doentes que năo ficavam bons até o final da novena eram, muitas vezes, deixados na casa de algum habitante do lugarejo, até a próxima festa da padroeira. Assim a população foi criando o hábito de acolher alienados e até de tratá-los como doentes. No primeiro capítulo de História da Loucura, Michel Foucault levanta a hipótese de que há relação entre uma certa experiência da loucura e uma forma de representá-la na literatura e na pintura através da imagem de naus de loucos, de doentes, que navegavam nos rios da região do Reno e nos canais de Flandres, na França: "E é possível que estas naus de loucos, que alimentaram a imaginação de toda a primeira fase da Renascença, 
A despeito de argumentos de ordem econômica e médica, o que esse tipo de assistência representa é a ampliação do campo de atuação da psiquiatria, não mais limitado às instituições asilares, mas aberto à amplitude do espaço social, por meio de uma prática que pretende abranger toda a comunidade, atuando sobre seu núcleo mais fundamental - a família.

A assistência familiar só pode se expandir na medida em que a psiquiatria já tenha desenvolvido nas populaçōes uma opiniáo medicalizada a respeito dos loucos e anormais. Ela exige que se acredite que, embora o cuidado do médico ao alienado seja imprescindível, nem sempre o tratamento manicomial é o mais eficaz. Idéia oposta àquela difundida pela psiquiatria no século XIX, para quem o hospício é o espaço terapêutico indispensável à cura do alienado.

Mais afastado do controle centralizado por parte do psiquiatra, esse tipo de assistência não deve, contudo, ameaçar o poder do alienista. $O$ poder do psiquiatra continuará a se exercer, indiretamente, por meio da criação de uma sociedade de assistência a esses doentes.

As colônias familiares não anulam os estabelecimentos existentes, nem constituem o tratamento mais conveniente para todas as espécies de alienados; porém, podem reduzir de modo prático e pouco dispendioso o crescimento desorganizado dos estabelecimentos de isolamento. Por essa razão, Juliano Moreira apóia os planos de Franco da Rocha de atribuir a algumas famílias a função de auxiliar o Hospital-Colônia de Juquery, em São Paulo.

tenham sido navios de peregrinação, navios altamente simbólicos de insensatos em busca de sua razão: uns desciam os rios do Reno, da Alemanha, em direção à Bélgica e a Gheel; outros subiam o Reno em direção ao Jura e a Besançon" (FoucAulr, 1972: 20). Trata-se, certamente, da figura de um tipo de exclusāo, em que os excluídos eram enviados rio afora, sem destino, para longe das cidades. De acordo com tal hipótese, barcos, que levavam insensatos de uma cidade a outra, existiram realmente. Os insensatos podiam circular livremente em campos afastados ou eram confiados a grupos de mercadores e de peregrinos. Este costume era freqüente, sobretudo na Alemanha. Os loucos eram presos pelas autoridades municipais e/ou entregues a marinheiros, para deles se livrarem em cidades afastadas da Europa. Segundo Foucault, em algumas cidades, importantes locais de passagem e de mercado, para onde os loucos eram levados, em número bastante considerável, eles eram "perdidos" pelos mercadores e marinheiros. Assim, purificava-se a cidade de onde os loucos eram provenientes. Foucault acha possível que esses lugares afastados tenham sido confundidos com os pontos para onde, ao contrário, os insensatos deveriam, de fato, ser conduzidos em peregrinação. Em todo caso, nesses pontos, a preocupação com a cura e com a exclusāo se misturavam. É possível, para Foucault, que a cidade de Gheel tenha se desenvolvido dessa maneira: "lugar de peregrinação tornando-se fechado, terra santa onde a loucura espera sua libertação, mas onde o homem opera, segundo velhos temas, como uma divisão mítica" (FOUCAULT, 1972:21). 
Juliano Moreira ressalta a importância do acompanhamento do paciente após sua alta, fora do hospital, por uma sociedade que deveria ser criada para esse fim. "É imprescindível, afirma ele, onde quer que haja assistência a alienados, a fundação de uma sociedade de proteção dos indivíduos que têm alta dos manicômios" (Moreira, 1906b:25). Mas lembra, antes de mais nada, que essa forma de assistência nem sempre é a melhor, tampouco anula a necessidade das outras formas terapêuticas inteiramente submetidas ao cuidado do médico alienista. "As colônias familiares não aniquilam os estabelecimentos existentes, não constituem a estada mais conveniente para todas as espécies de alienados" (Moreira, 1906b:25).

Essa sociedade seria, portanto, mais um elemento de controle da população, agora realizado também na função de cuidar da reinserção do doente em seu meio social. Como explica Juliano Moreira em 'Ligeiras notas a propósito da assistência familiar', de 1906:

Essas sociedades devem ter por missão não somente cuidar dos orates depois da saida dos asilos, mas ainda dar-lhes cuidados antes e durante sua internação, indo até junto aos membros da familia do alienado, dando-lhes assistência se necessário for, procurando quanto possivel dar combate direto a todas as causas predisponentes e ocasionais da alienação e da degenerescência mentais. (Moreira, 1906b:25)

Tal controle se exerce também na seleção das famílias que cooperarão com a assistência familiar, que deverão comprovar-se idôneas, na concepção dos psiquiatras, para esta tarefa:

Anexo ao hospital-colônia, em seus limites, deve o Governo construir casinhas para alugar às familias dos bons empregados, que poderão receber pacientes suscetiveis de serem tratados em domicilio: far-se-á assim assistência familiar. Se nas redondezas houver gente idônea a quem se possa confiar alguns doentes, poder-se-d ir estendendo essa assistência heterofamiliar $e$ até se tentar a homofamiliar. (Moreira, 1910:384)

Juliano Moreira preconiza a ajuda financeira do governo aos encarregados dos cuidados do louco e, sobretudo, à supervisão a ser realizada por pessoal especializado, fazendo aparecer, assim, uma nova forma de atuação - indireta - da psiquiatria fora dos limites do hospital.

Com os dois tipos de assistência familiar, hetero ou homofamiliar, que constituem, de acordo com Juliano Moreira, "a forma mais natural, mais livre, e menos dispendiosa de assistir” (Moreira,1906b:25) ao alienado, a psiquiatria estabelece novas práticas psiquiátricas. Individualizantes, tais práticas, ao caucionar racionalmente a intervenção do Estado, ajudam na regularizaçáo do espaço social, contribuindo com a tarefa de ordenamento social, ressaltando a necessidade de um reforço na imposiçăo da nova ordem estatal. 


\section{O AMBULATÓRIO}

O estabelecimento de ambulatórios em hospitais passa a ser recomendado na esteira de uma política de educação da população para prevenção das moléstias, por meio da difusão dos conhecimentos de higiene e do emprego dos processos de diagnóstico e tratamento precoces. Sua função, de acordo com documento de 1924, redigido por Rodrigues Caldas - 'O fim da velhas colônias da Ilha do Governador e suas transferências para a nova colônia no continente. Colônia de Alienado' -, indica uma correspondência com o ideal da eugenia, principal justificativa da criação do ambulatório. Mais do que proporcionar assistência aos moradores da região, caberia ao ambulatório da colônia propagar conselhos de higiene. Nas primeiras décadas do século $\mathrm{XX}$, o ambulatório é planejado no âmbito da eugenia, então um dos principais fatores para a implantação de um sistema de assistência médica; é considerado um importante fator de aprimoramento eugenético da população.

O ambulatório deve proporcionar os recursos para a assistência de todas as enfermidades determinantes de 'moléstias mentais e nervosas', bem como possibilitar ao médico o contato com a população vizinha. $\mathrm{O}$ objetivo proposto é internar o menor número possível de doentes e dar a maior quantidade possivel de altas aos internos, reduzindo os custos do hospital.

Estando a prática psiquiátrica aberta a diversas formas de assistência, o atendimento especializado do psiquiatra poderia estender-se, com especificidade, a um número maior de alienados, permitindo que uma ação mais geral fosse dirigida a todos os indivíduos classificados como anormais, ao mesmo tempo que particulariza cada caso, abrangendo até o alienado em potencial.

\section{A Assistencia Psiquiatrica nas Forças Armadas}

No século XX, a prática psiquiátrica começa a interferir em toda a sociedade, penetrando nos setores mais variados, apoiada na idéia de preservaçāo da ordem social e da nossa saúde mental, atuando sobre os mais importantes focos de poder da sociedade, como a família, a opiniáo pública, a lei e as Forças Armadas.

Os distúrbios mentais nos exércitos, considerados grande prejuízo à disciplina, são então assimilados à idéia de prevençāo, por meio de cuidadosa seleçáo do voluntariado, e começam a ser vistos em uma nova perspectiva. 
Em conferência realizada no Clube Militar em 1918, sob os auspícios da Sociedade Médico-Cirúrgica Militar, Juliano Moreira chama a atenção para o fato de que tais distúrbios causam prejuízo à disciplina militar, "quando danos maiores não são causados à própria pátria, como delitos de fuga, abandono de posto, deserção, insubmissão, incêndios voluntários, roubos etc. que desaparecerão do exército tanto mais quanto melhor for a seleção do voluntariado" (Moreira, 1918:122). Para a formação das fileiras, há uma transferência da ênfase na quantidade de soldados, na maioria aceitos para fazer número - "que em mais de $80 \%$ dos casos" (Moreira, 1918:122) são responsáveis por grandes problemas nos exércitos -, para a ênfase na qualidade do soldado.

Nessa conferência dirigida aos militares, Juliano Moreira associa a necessidade de se recorrer à medicina mental nas Forças Armadas à nova concepçáo militar do soldado - "mens sana in corpore sano" (Moreira, 1918:122) -, mostrando o quanto essa concepção se liga não mais apenas à saúde do corpo, ${ }^{82}$ mas também à saúde mental. A nova concepção de soldado espelha uma vida militar mais complexa, preocupada em ser "espiritualizada" (Moreira, 1918:122), de acordo com o enfoque prioritário de uma educação que não pode permitir que se desenvolvam personalidades doentias. A função do instrutor militar se transforma, tornando-se necessário que ele seja capaz de fornecer uma educação mental saudável, pois o soldado deverá ter uma inteligência capaz de conduzir o corpo que anima. Assim, afirma Juliano Moreira:

Ao instrutor não basta desenvolver pelo método monótono da repetição mais alguns centros reflexos da medula. O dominio do catatonismo e da estereotipia vai sendo relegado a um segundo plano e de todo näo desaparece, porque é preciso transigir com o passado e näo tirar ao panorama militar os encantos das exterioridades que por certo ainda atraem $50 \%$ dos jovens alistados (...) ao treinamento fisico de outrora acresceu-se a educaçäo mental e 0 soldado de boje deve ter uma inteligência estritamente senhora do corpo que anima. (Moreira, 1918:122)

A prática psiquiátrica se impōe, portanto, nas Forças Armadas, como necessária à ordem e à disciplina, pois cuidando-se do estado mental do

\footnotetext{
${ }^{82}$ As qualidades exigidas para um bom soldado não são mais as mesmas. A docilidade do corpo concebido como máquina era, até então, a característica mais importante a ser imprimida no soldado: "O soldado", afirma Juliano Moreira, "deveria ser mais um conjunto dócil de alavancas do que uma inteligência vigilante, servida por órgáos, mais um instrumento do que um artífice de vitória, mais um guerreiro como definira Lycurgo, do que um homem coerente o exigiria Solon" (Moreira, 1918:121).
} 
soldado será possível evitar uma série de delitos comuns nos exércitos, sobretudo nas épocas de crises sociais e de guerra, quando seus serviços se fazem mais necessários. Esse é o argumento de Juliano Moreira, ao mostrar, com cifras de guerras de todo o mundo, que os distúrbios mentais aumentam muito nessas ocasiōes, alertando para o prejuízo que a presença de alienados nas fileiras pode ocasionar.

Juliano Moreira mostra que vários países europeus incrementaram a assistência psiquiátrica militar, a partir da guerra mundial, criando centros de neuropsiquiatria, e acrescenta que seus serviços têm concorrido para a diminuiçáo de desequilibrados nas fileiras, ao aconselhar na seleção dos soldados, e ao classificar os soldados que sofrem de distúrbios mentais, aceitos nos exércitos para se ter maior número de soldados nas fileiras, discriminando-os convenientemente para outros serviços do país, segundo a conveniência de cada caso.

Ele sugere as seguintes medidas profiláticas e preventivas: tornar obrigatório exame mental nos soldados; fazer obrigatória a frequiência do médico militar a clínicas psiquiátricas e neurológicas; compor uma comissão de especialistas para perícia psiquiátrica em toda capital; reservar uma enfermaria para observação e tratamento de casos neuropsicológicos nos hospitais militares; haver sempre um médico nos conselhos de guerra, que seja também alienista; instituir o curso de psicologia mórbida nas escolas militares para melhor aproveitamento do esforço pedagógico do oficial, para instruí-lo, desenvolver-lhe a educação moral, fortificar-lhe a coragem, inculcar-lhe o justo uso da iniciativa e o sentimento da disciplina (Moreira, 1918).

Resumindo, uma série de medidas de prevenção contra a doença mental que começaram a ser efetivadas nas Forças Armadas, juntamente com a campanha antivenérea e antialcoólica, que os psiquiatras se empenharam em defender, inclusive nos meios militares, reforça ainda mais a função disciplinar que a prática psiquiátrica do século $\mathrm{XX}$ começa a exercer sobre toda a sociedade. 


\section{Conclusão}

A psiquiatria brasileira do início do século $\mathrm{XX}$, inaugurada por Juliano Moreira, constitui, tanto ao nível do saber quanto da prática, um momento de ruptura em relação às teorias e às práticas psiquiátricas precedentes, que, por uma abertura em seu próprio discurso, permitiu a crítica e seu abandono, constituindo as condições de possibilidade do surgimento do novo modelo e das transformaçōes aqui analisados.

Embora não tenha sido claramente formulada do ponto de vista conceitual, há uma descontinuidade que se estabelece sobretudo a partir do surgimento, no final do século XIX, da concepção de anormalidade como pertencendo ao campo da patologia, que se estende a todos os indivíduos reconhecidos como fora da ordem social, fora da norma, sejam eles degenerados, criminosos, imbecis, ou débeis mentais.

Ao nível do saber psiquiátrico, o conceito de anormal responde à questão de uma etiologia específica para cada tipo de doença mental, pesquisada em suas origens mais remotas, incluindo os casos limítrofes, em 'que há apenas a degeneração em potencial, ou potencialidade de degeneração, considerada como um processo passível de desencadear psicopatologias, em oposição à generalidade etiológica da psiquiatria moral do século XIX.

Contudo, a concepção de anormalidade corresponde, mais do que à questão da causalidade, à necessidade de se combater, preventiva e 
profilaticamente, os problemas sociais decorrentes do comportamento indisciplinável dos indivíduos que não podiam ser considerados loucos propriamente, nem tampouco normais.

A nova categoria dos anormais se sobrepóe ao par normal-doente mental do século XIX, tornando a açāo da psiquiatria mais específica, dirigindo-se a cada tipo particular de anormalidade, tornado-se, ao mesmo tempo, mais abrangente, assistindo a um número muito maior de indivíduos nocivos à sociedade, a partir da possibilidade de sua recuperação através de uma intervenção fundada num saber médico "científico".

No século XX, esta categoria permite, por um lado, justificar cientificamente as medidas de repressão aos indivíduos indisciplinados, dando a ilusão de eliminar a idéia negativa de uma reclusão que consistiria apenas numa maneira ágil e fácil de afastá-los da sociedade. Por outro lado, ela fornece à psiquiatria uma das condiçóes de possibilidade de ultrapassar seus próprios limites, o doente mental e o hospício, para abranger todos os indivíduos desde a criança normal, através de normas de um projeto de educacional de prevenção à anormalidade, até o adulto louco ou degenerado, penetrando em outras instâncias sociais como a familia, a escola, as Forças Armadas. Ao mesmo tempo, a anormalidade vai modificar radicalmente os preceitos da assistência psiquiátrica, ao ser coetânea da elaboração da noção de "personalidades psicopáticas", nova classe nosológica que a medicina mental tenta explicitar, ao apontar a necessidade de criação de novas modalidades de assistência médica.

A prática psiquiátrica, que no século XIX era uma ação restrita à medicalização $\cdot e$ psiquiatrização no espaço do hospício, no século XX a medicalização abre-se a outras instâncias sociais, baseada no conceito abrangente de anormalidade, que permite a instituição de novos espaços terapêuticas e preventivos e a criação de um sistema de assistência totalmente novo.

Este novo sistema opera um deslocamento do campo da psiquiatria, que no século XIX se dirigia apenas ao doente mental, para diversas espaços e modalidades asilares, como a colônia agrícola e o manicômio judiciário, e mesmo não asilares, como a assistência familiar e o ambulatório, criadas para assistir ao novo tipo de população objetivada pela psiquiatria, que é a população dos desviantes, alcoólatras, sifilíticos, epiléticos, delinqüentes, diferenciados dos doentes mentais propriamente. 
As diferentes formas de assistência, resultantes da ampliação do objeto da psiquiatria à anormalidade, não representam apenas variantes da assistência aos alienados do século XIX. Elas estabelecem uma descontinuidade, que as faz diferir de uma prática baseada no princípio do isolamento de Esquirol ao passar para o regime do open-door. Enquanto no primeiro o afastamento de qualquer vínculo com a sociedade é imprescindível à terapêutica e justifica a criação do asilo fechado, no regime do open-door tentase justamente restabelecer este vínculo, através de passeios, do aspecto alegre das enfermarias, da construçáo de pequenas vilas para os doentes mais sociáveis. Enquanto, no século XIX, a terapia deve-se impor através de medidas fortes de repressão, no século XX o doente deve ter a ilusão de liberdade, que o tranqüiliza, deixando-o menos rebelde e mais suscetivel à ordem disciplinar, a que a terapia visa fundamentalmente, reforçando a relação da psiquiatria com a idéia de homem normal, trabalhador tranqüilo, força produtiva.

Ao nível da prática, essa ruptura corresponde ao novo projeto de normalização e medicalização da população, numa sociedade em vias de implantar um programa de governo com um poder que não é mais o do soberano. Pois, é coetâneo do novo modo de produçáa, o da República, instaurando-se através de um regime em que não se compra e vende mais o trabalhador, mas a força de trabalho que todos os individuos representam. O desdobramento do campo da psiquiatria à anormalidade constitui este novo projeto, ligando-o às noçōes de higiene mental e de conhecimento das causas da doença mental e da anormalidade, e às medidas de combate à doença mental, ao grande contingente de improdutivos e à alta taxa de criminalidade dela derivados. 


\section{REFERÊNCIAS BibLIOGRÁFICAS E Fontes}

\section{REFERENCIAS BIBLIOGRÁFICAS}

Amarante, P. Asilos, alienistas e alienados. A Saúde no Brasil, 1(3):149-152, 1983.

Amarante, P. (Org.) Psiquiatria Social e Reforma Psiquiátrica. Rio de Janeiro: Editora Fiocruz, 1994.

AMARANTE, P. (Org.) Loucos pela Vida: a trajetória da reforma psiquidtrica no Brasil. Rio de Janeiro: Editora Fiocruz, 1995.

AMARANTE, P. Forças e diversidade: as transformaçōes na saúde e na loucura. In: BRANCO, G. C. et al. (Orgs.) Michel Foucault: da arqueologia à estética da existência. Londrina, Rio de Janeiro: Cefil, Nau, 1998.

Amarante, P. (Org.) A Loucura da História. Rio de Janeiro: Laps/Ensp/Fiocruz, 2000.

Birman, J. A Psiquiatria como Discurso da Moralidade. Rio de Janeiro: Graal, 1978.

Branco, G. C. \& Portocarrero, V. (Orgs.) Retratos de Foucault. Rio de Janeiro: Nau, 2000.

Canguilhem, G. Le Normal et le Pathologique. Paris: PUF, 1966.

CARRARA, S. L. Crime e Loucura: o aparecimento do manicômio judiciário na passagem do século, 1987. Dissertação de Mestrado, Rio de Janeiro: Museu Nacional, Universidade Federal do Estado do Rio de Janeiro.

CarvalHal, L. A. \& Delgado, P. G. Levantamento das fontes primárias e secundárias relativas a Juliano Moreira (1873-1933). In: AmARANTE, P. (Org.). A Loucura da Historia. Rio de Janeiro: Laps/Ensp/Fiocruz, 2000. 
CARVALHO, A. Para a compreensāo do processo de produçáo discursiva da higiene mental no Brasil. In: AMARANTE, P. (Org.). A Loucura da História. Rio de Janeiro: Laps/Ensp/ Fiocruz, 2000.

CASTEL, R. L'Ordre Pschyatrique: l'age d'or de l'aliénisme. Paris: Minuit, 1976.

CASTEL, R. La Gestion des Risques: de l'anti-psychiatrieà l'aprè psychanalise. Paris: Minuit, 1984.

Costa, J. F. História da Psiquiatria no Brasil. Rio de Janeiro: Documentário, 1976.

Costa, J. F. Psiquiatria preventiva e representação da doença mental. In: História da Psiquiatria no Brasil. 4.ed. Rio de Janeiro: Xenon, 1989.

Deleuze, G. Un Nouvel Archiviste: Foucault. Paris: Minuit, 1986.

DreYFus, H. \& RaBINOw, P. Uma Trajetória Filosófica: para além do estruturalismo e da hermenêutica. Trad. Antônio Carlos Maia e Vera Portocarrero. Rio de Janeiro: Forense Universitária, 1995.

ENGEL, M. G. A. Fontes para uma história das concepçóes acerca da loucura na Cidade do Rio de Janeiro (1830-1930), 1993. Relatório de Pesquisa, Rio de Janeiro: Universidade Federal Fluminense/CNPq.

ENGEL, M. G. A Loucura na Cidade do Rio de Janeiro: ideias e vivências (1830-1930), 1995. Tese de Doutorado, Campinas: Instituto de Filosofia e Ciências Humanas, Universidade Estadual de Campinas.

FonsECA, M. Normalização e direito. In: BranCo, G. C. \& PorToCARRERo, V. (Orgs.) Retratos de Foucault. Rio de Janeiro: Nau, 2000.

Foucautr, M. Les Mots et les Choses. Paris: Gallimard, 1966.

Foucaurt, M. L'Archéologie du Savoir. Paris: Gallimard, 1969.

Foucaurt, M. Histoire de la Folie à l'Âge Classique. Paris: Gallimard, 1972.

FouCAUIT, M. Surveiller et Punir: naissance de la prison. Paris: Gallimard, 1975.

Foucaut, M. Naissance de la Clinique. Paris: PUF, 1963. Nascimento da Clinica. Rio de Janeiro: Forense Universitária, 1977a.

Foucaurt, M. Historia da Sexualidade I: a vontade de saber. Trad. M. T. C. Albuquerque e J. A. G. Albuquerque. Rio de Janeiro: Graal, 1977b.

FouCAULT, M. Microfisica do Poder. Organização e introdução de Roberto Machado. 3.ed. Rio de Janeiro: Graal, 1982.

Foucaurt, M. Les grandes fonctions de la médecine dans notre société. In: FouCAULT, M. Dits et Ecrits, vol. II. Paris: Gallimard, 1994.

Foucault, M. Dits et Ecrits. Paris: Gallimard, 1994. 4 v.

Foucaut, M. A Verdade e as Formas Juridicas. Trad. Roberto Cabral de Melo Machado e Eduardo Jardim Morais. Rio de Janeiro: Nau, 1999. 
GARCIA, R. Historia de una Ruptura: el ayer y el hoy de la psiquiatria española. Barcelona: Virus Editorial, 1995.

MACHADO, R. et al. Daną̧ão da Norma. Rio de Janeiro: Graal, 1978.

MACHADO, R. Ciência e Saber: a trajetória de Michel Foucault. Rio de Janeiro: Graal, 1981.

MACHADO, R. Foucault, a Filosofia e a Literatura. Rio de Janeiro: Jorge Zahar, 2000.

Pereira, C. R. Os Carreiristas da Indisciplina. Rio de Janeiro: Achiamé, 1979. (Textos paralelos).

PORTOCARRERO, V. O Dispositivo da Sauide Mental uma metamorfose na psiquiatria brasileim, 1990. Tese de Doutorado, Rio de Janeiro: Departamento de Filosofia do Instituto de Filosofia e Ciências Sociais, Universidade Federal do Estado do Rio de Janeiro.

PorToCarrero, V. Foucault: a história dos saberes e das práticas. In: PorTOCARRERo, V. (Org.) Filosofia, Historia e Sociologia das Ciências 1: abordagens contemporâneas. Rio de Janeiro: Editora Fiocruz, 1998.

REIs, J. R. F. Rą̧a, naçāo e psiquiatria: o projeto eugênico da Liga Brasileira de Higiene Mental. In: Amarante, P. (Org.) A Loucura da Historia. Rio de Janeiro: Laps/Ensp/ Fiocruz, 2000.

Roudinesco, E. et al. Foucault: leituras da historia da loucura. Trad. Maria Inês Duque Estrada. Rio de Janeiro: Relume Dumará, 1994.

SERRA, A. A. A psiquiatria como discurso político. Colefão Textos Paralelos. Rio de Janeiro: Achiamé, 1979.

VEYNE, P. Como se Escreve a História e Foucault Revoluciona a História. Trad. Alda Baltar e Maria Auxiliadora Kneipp. 4.ed. Brasília: EdUnB, 1998.

\section{FonTES PRIMÁRIAS}

ALMEIDA, W. O diagnóstico, as remissóes e o tratamento dos dementes precoces. Arquivos Brasileiros de Psiquiatria, Neurologia e Medicina Legal, 1917.

ANDRADA, B. Paranóia. Arquivos Brasileiros de Psiquiatria, Neurologia e Medicina Legal, 1916.

ARRUDA, E. Preferência e inadvertências por certas tarefas e a higiene mental. Arquivos Brasileiros de Psicotécnica, 1959.

Austregésilo, A. Psicoses inficiosas nas doenças tropicais. Arquivos Brasileiros de Neuriatria ePsiquiatria, 1919.

BaYle, A. L. J. Nouvelle Doctrine des Maladies Mentales. Paris: s. n., 1825.

BRANDĀo, J. C. T. Os alienados no Brasil. Arquivos Brasileiros de Neuriatria e Psiquiatria, 5-52, 1956. 
CalDAS, R. O Fim das Velhas Colonias da Ilha do Governador e suas Transferências para a Nova Colónia no Continente. Rio de Janeiro: Colônia de Alienados, 1924.

Calmon, P. Palacio da Praia Vermelha. Rio de Janeiro, 1952.

CAMILlO, H. Consideraçōes sobre a medicina legal, a repressāo e a profilaxia dos anômalos morais perigosos. Arquivos Brasileiros de Neuriatria e Psiquiatria, 1920.

Carrilho, H. A colaboração dos psiquiatras nas questōes penais. Arquivos do Manicômio Judiciário, 1930.

Charcot, J. M. L'Hystérie. Textes choisis et présentés par E. Trillat, Rhadamante, Privat Ed., 1971.

Esquirol, J. E. D. Des Maladies Mentales Considérées sous le Rapport Médical, Hygiénique et Médico-Legal. Paris, 1838. [tomos I e II]

EY, H. Encyclopédie Médico-Cbirurgicale, N, 12, 1975, 37005 A 10.

KRAEPELIN, E. Trattato di Psichiatria. Traduzione della VII edizione originale per il dottor Cuido Guido. Milano: F. Vallardi, 1, 1856-1926. [4 v.]

LoPes, I. C. Primeiro hospital psiquiátrico do Brasil. Arquivos Brasileiros de Neuriatria e Psiquiatria, 1934-1935.

LOPES, I. C. Notícia história da assistência a psicopatas no Distrito Federal. Arquivos Brasileiros de Neuriatria e Psiquiatria, 22, 1939.

LOPES, I. C. Aspectos da higiene mental no Brasil. Arquivos Brasileiros de Neuriatria e Psiquiatria, 1940-1942.

Moreira, J. A sífilis como fator de degeneração. Gazeta Médica da Babia, 3, 1899-1900.

MoreIRA, J. Clinoterapia, Difusäo e Resultados no Tratamento das Psicoses. Rio de Janeiro: Record, 1901.

Moreira, J. Assistência aos epiléticos. Colônias para eles. Arquivos Brasileiros de Psiquiatria, Neurologia e Ciências Afins, ano 1(2), 1905a.

MOREIRA, J. Assistência nos estados de 1852 a 1892 . Arquivos Brasileiros de psiquiatria e Ciências Afins, ano 1(1), 1905 b.

Moreira, J. Psicoses em leprosos. Arquivos Brasileiros de Psiquiatria, Neurologia e Ciências Afins, (1), 1906a.

Moreira, J. Ligeiras notas a propósito da assistência familiar. Arquivos Brasileiros de Psiquiatria, Neurologia e Ciências Afins, ano 2(1), $1906 \mathrm{~b}$.

MoreIRA, J. Um caso de paranóia. Arquivos Brasileiros de Psiquiatria, Neurologia e Ciências Afins, ano III(3-4), 1907.

Moreira, J. Assistência a alienados na Alemanha, Clínica de Munich. Arquivos Brasileiros de Psiquiatria, Neurologia e Ciências Afins, ano IV, 1908a. 
MOREIRA, J. Querelantes e pseudo-querelantes. Arquivos Brasileiros de Psiquiatria, Neurologia e Ciências Afins, 1908b.

MoreIRA, J. Quais os melhores meios de assistência aos alienados. Arquivos Brasileiros de Psiquiatria, Neurologia e Medicina Legal, 1910.

Moreira, J. Delírio paranóide de longa duração. Arquivos Brasileiros de Psiquiatria, Neurologia e Medicina Legal, 8, 1912a.

MoreirA, J. Falsos testemunhos por desvios mentais. Arquivos Brasileiros de Psiquiatria, Neurologia e Medicina Legal, 8, 1912b.

MoREIRA, J. Contribuiçáo ao estudo de demência paralítica no Rio de Janeiro, especialmente no Hospital Nacional - em colaboraçáo com o Dr. Ulisses Vianna. $1^{\circ}$ Congresso Brasileiro de Neurologia, Psiquiatria e Medicina Legal, 1916.

MoreirA, J. A psiquiatria e a guerra. Conferência realizada no Clube Militar em 4/2/1918, sob os auspícios da Sociedade Médico-Cirúrgica Militar, Capital Federal, 1918.

Moreira, J. Classificaçōes em medicina mental. Arquivos Brasileiros de Neuriatria e Psiquiatria, 1919.

MOREIRA, J. Discurso pronunciado pelo professor Juliano Moreira no ato do lançamento da pedra fundamental do Manicômio Judiciário. Arquivos Brasileiros de Neuriatria e Psiquiatria, 1920a.

MoREIRA, J. A questão da incapacidade civil. Arquivos Brasileiros de Neuriatria e Psiquiatria, $1920 \mathrm{~b}$.

MOREIRA, J. O novo agrupamento nosográfico das doenças mentais do Prof. Kraepelin. Arquivos Brasileiros de Neuriatria e Psiquiatria, 1921.

MoreirA, J. As diretrizes da higiene mental entre nós. Revista de Medicina e Higiene Militar, 1922.

MoREIRA, J. A seleção individual de imigrantes no programa de higiene mental. Arquivos Brasileiros de Higiene Mental, 1925.

Moreira, J. Aniversário de fundaçăo do Hospital Nacional de Psicopatas. Arquivos Brasileiros de Neuriatria e Psiquiatria, 1927-1928.

Moreira, J. Fatores hereditários em psiquiatria. Arquivos Brasileiros de Higiene Mental, out.1929a.

Moreira, J. Reformatórios para alcoolistas. Arquivos Brasileiros de Higiene Mental, nov. $1929 \mathrm{~b}$.

MOREIRA, J. Notícia sobre a evolução da assistência a alienados no Brasil. Arquivos Brasileiros de Neuriatria e Psiquiatria, Rio de Janeiro, 1955. 
Moreira, J. \& Austregesilo, A. Ata de sessão solene extraordinária realizada a 26 de março de 1923, comemorativa do $20^{\circ}$ aniversário da direção do Prof. Juliano Moreira na Assistência a Alienados Federal. Arquivos Brasileiros de Neuriatria e Psiquiatria, 1923.

Moreira, J. \& PeiXoto, A. Classificação das moléstias mentais do Prof. Emil Kraepelin. Arquivos Brasileiros de Psiquiatria, Neurologia e Ciências Afins, ano 1(2):204, 1905.

Moreira, J. \& PexXoto, A. A paranóia e as síndromas paranóides. Arquivos Brasileiros de Neuriatria e Psiquiatria, 1914.

Moreira, J. \& Peixoto, A. Les maladies mentales dans les climats tropicaux. Arquivos Brasileiros de Neurologia, Psiquiatria e Medicina Legal, Rio de Janeiro, 1915.

Mores, B. A. Traité des Dégérescences Physiques, Intelectuelles et Morales de l'Espèce Humaine et des Causes qui Produisent ces Variettés Maladives. Paris: J. R. Baillère, 1857.

Morel, B. A. Le no-restreint. Paris: J. R. Baillère, 1860.

Noticiário. Assistência a psicopatas. Inauguração do Núcleo Ulysses Vianna. Arquivos Brasileiros de Neuriatria e Psiquiatria, 1938.

Peixoto, A. Neuro-psiquiatria. Jubileu do Professor Juliano Moreira. Arquivos Brasileiros de Medicina, 1931.

Penafiel, C. O professor Juliano Moreira. Arquivos Brasileiros de Psiquiatria, Neurologia e Medicina Legal, 1913.

Peres, H. Classificação das doenças mentais organizada pela Divisão de Assistência a Psicopatas. Ata da sessão extraordinária de psiquiatria de 31/10/1933. Arquivos Brasileiros de Neuriatria e Psiquiatria, 21-22, 1938-1939.

Pomme, P. Traité des Affections Vaporeuses des Deux Sexes, I. 4.ed. Lyon: s. n., 1769.

Professor Juliano Moreira. Arquivos do Manicômio Judiciário, Rio de Janeiro, 1931.

RoCHA, F. Hospicio e Colônias de Juquery São Paulo: Tipografia Brasil Rothsehild e Co., 1912.

Rodrigues, N. Legislação sobre assistência a alienados. Arquivos Brasileiros de Psiquiatria, Neurologia e Ciências Afins, 1906.

Roxo, H. B. B. Sexualidade e demência precoce. Arquivos Brasileiros de Neuriatria e Psiquiatria, 1919. 


\author{
Formato: $16 \times 23 \mathrm{~cm}$ \\ Tipologia: AGaramond \\ Papel: Pólen Bold $70 \mathrm{~g} / \mathrm{m}^{2}$ (miolo) \\ Cartão supremo $250 \mathrm{~g} / \mathrm{m}^{2}$ (capa) \\ Fotolitos: Laser vegetal (miolo) \\ Engenho e Arte Editoraçāo Gráfica Ltda. (capa) \\ Impressão e acabamento: Millennium Print Comunicação Visual Ltda. \\ Rio de Janeiro, dezembro de 2002. \\ Não encontrando nossos títulos em livrarias, \\ contactar a EDITORA FIOCRUZ: \\ Av. Brasil, 4036 - $1^{2}$ andar - sala 112 - Manguinhos \\ 21040-361 - Rio de Janeiro - RJ \\ Tel.: (21) 3882-9039 e 3882-9041 \\ Telefax: (21) 3882-9006 \\ http://www.fiocruz.br/editora \\ e-mail: editora@fiocruz.br
}

